\title{
Rapid eruptive transitions from low to high intensity explosions and effusive activity: insights from textural analysis of a small-volume trachytic eruption, Ascension Island, South Atlantic
}

\author{
Bridie V. Davies ${ }^{1}$ (D) Richard J. Brown ${ }^{2} \cdot$ Jenni Barclay $^{1} \cdot$ Jane H. Scarrow ${ }^{3} \cdot$ Richard A. Herd $^{1}$
}

Received: 6 April 2021 / Accepted: 5 July 2021 / Published online: 6 August 2021

(C) The Author(s) 2021

\begin{abstract}
Proximal deposits of small-volume trachytic eruptions are an under-studied record of eruption dynamics despite being common across a range of settings. The $59 \pm 4$ ka Echo Canyon deposits, Ascension Island, resulted from a small-volume explosiveeffusive trachytic eruption. Variations in juvenile clast texture reveal changes in ascent dynamics and transitions in eruption style. Five dominant textural types are identified within the pumice lapilli population. Early Strombolian-Vulcanian eruption phases are typified by macro- and micro-vesicular equant clast types. Sheared clasts are most abundant at the eruption peak, transitioning to dense clasts in later phases due to shear-induced coalescence, outgassing and vesicle collapse. Melt densification and outgassing via tuffisite veins increased plume density, contributing to partial column collapse and the explosive-effusive transition. Bulk vesicularity distributions indicate a shift in dominant fragmentation mechanism during the eruption, from early-stage bubble interference and rupture to late-stage transient fragmentation, with a transient peak of Plinian activity. Dome and lava groundmass crystallinities of up to $70 \%$ indicate near-complete degassing during effusive phases, followed by shallow over pressurisation and a final less explosive phase. We provide textural evidence for high-intensity explosive phases and rapid transitions in eruptive style during small-volume trachytic eruptions and consider the impact of trachytic melt compositions on underlying dynamics of these short-lived, explosive events. This analysis demonstrates the value of detailed stratigraphy in understanding critical changes in eruption dynamics and the timescales over which they may occur which is of particular value in anticipating future eruptions of this type.
\end{abstract}

Keywords Pumice $\cdot$ Juvenile clast texture $\cdot$ Vesicularity $\cdot$ Ascent dynamics

\section{Introduction}

Small-volume silicic eruptions are common across a range of settings and exhibit the diverse eruption styles shown in Table 1. Relative to large-volume calc-alkaline eruptions,

Editorial responsibility: L. Pioli

Bridie V. Davies

Bridie.Davies@uea.ac.uk

1 School of Environmental Sciences, University of East Anglia, Norwich Research Park, Norwich, Norfolk NR4 7TJ, UK

2 Department of Earth Sciences, Durham University, Durham DH1 3LE, UK

3 Departamento de Mineralogía y Petrología, Facultad de Ciencias. Avda. Fuentenueva s/n, Universidad de Granada,

18071 Granada, España the ascent dynamics of often alkali-rich small-volume eruptions are relatively under-studied. Small-volume silicic eruptions typically occur as late-stage activity associated with larger volcanic features, e.g. calderas (Cole et al. 1995; Hernando et al. 2019), shield volcanoes (Shea et al. 2017) and flank fissures (Katsui and Katz 1967; Pistolesi et al. 2015) (Table 1). The evolution and eruption of these small-volume magmas may be governed by the low flux of incoming eruptible melt and crustal heterogeneity (Chamberlain et al. 2019). Scarcity of eruptible melt has been attributed to long-term, low magma-production rates, such as at Ascension, and/or significant reservoir depletion by earlier activity, such as often leads to caldera formation (Table 1).

Direct observations and inferences from preserved deposits show that small-volume silicic eruptions are capable of intense short-lived explosive phases with few precursory signals, important transitions in eruption style and pulsatory activity capable of generating pyroclastic density currents 


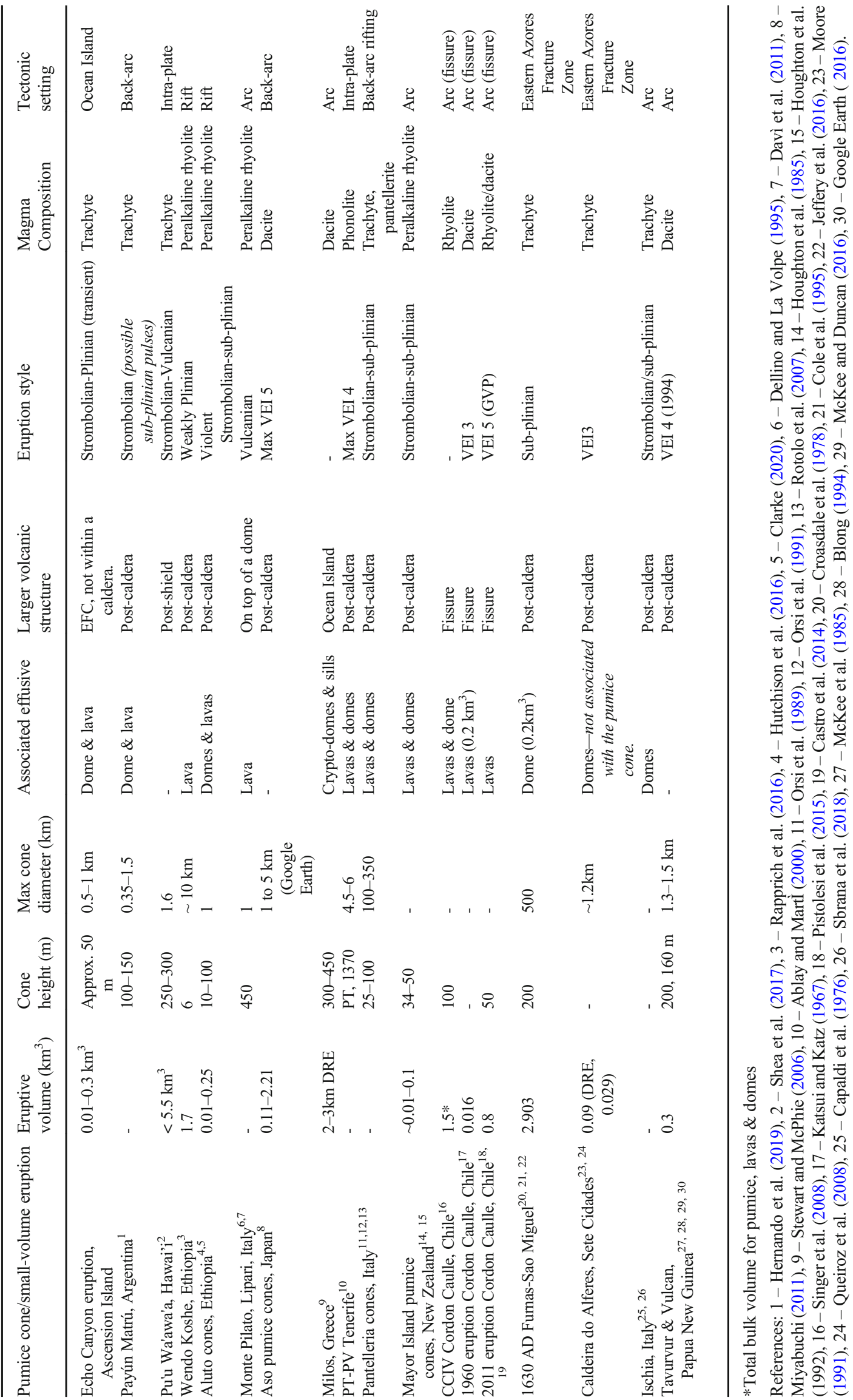


(PDCs) (Table 1). Thus, a critical challenge for volcanic hazard assessment is to recognise the fingerprint and drivers of such variability in eruptive style through the interrogation of remaining deposits; set against challenges from the poor preservation (Preece et al. 2021) or minimal exposure (e.g. Hernando et al. 2019) typical of these eruptions, a consequence of low initial eruptive volumes, air fall offshore (for small ocean islands) and destruction by subsequent eruptions and erosion. To complement stratigraphic investigations of erupted deposits, studies of juvenile clast texture have provided key insights into eruption dynamics of larger silicic eruptions (e.g. Polacci et al. 2003; Alfano et al. 2012; Preece et al. 2014). Such textures represent an integrated history of meltgas-crystal-strain interactions in ascending magma (Houghton and Wilson 1989), for the most part preserved at the point of fragmentation. Microscopic changes to vesicle textures can occur post-fragmentation, particularly where viscosities are low, and vesicles well connected (Gardner et al. 2017). However, this study focusses on bulk vesicularity and macro-scale clast textures in hand specimen. Postfragmentation modifications should, therefore, have a minimal impact on the dominant clast textures and resulting interpretations discussed here. For more detailed quantification of vesicle textures, e.g. vesicle size distributions (Shea et al. 2010), these modifications must be accounted for; however, this is beyond the scope of this study. The bulk properties of deposits identified from differing stratigraphic horizons in the field can be used to interpret the drivers of changing eruption dynamics such as the development of heterogeneous pressure gradients, shear zones or plug formation and destruction (e.g. Schipper et al. 2013; Saubin et al. 2016; Shea et al. 2017). Analysis of juvenile clast texture is thus a powerful tool for reconstructing ascent and eruption dynamics of un-observed eruptions.

Trachytic melts have a lower viscosity than their calcalkaline equivalents (Whittington et al. 2001; Giordano et al. 2004) which influences bubble structure and outgassing. Investigations of clast texture are thus particularly important for reconstructing and understanding the dynamics of these lesser-studied eruptions. Experimentation, modelling and textural studies have recently improved our understanding of the physical properties and ascent dynamics of alkali-rich melts (Giordano et al. 2004; Arzilli and Carroll 2013; Fanara et al. 2013; Shea et al. 2017). The idea that trachytic melts are "kinetically reactive" facilitating complex ascent and eruption dynamics is gaining traction. The basis for this is their low viscosity, high $\mathrm{H}_{2} \mathrm{O}$ diffusivity, rapid degassing and vesiculation and tendency to crystallise microlites rapidly in response to perturbation (Shea et al. 2017; Deniel et al. 2020).

To date, reconstruction of small-volume alkali-rich eruptions has largely focussed on longer-term volcanic histories rather than individual episodes (Buck et al. 1981; Mahood and Hildreth 1986; Rotolo et al. 2007; Singer et al. 2008; Vezzoli et al. 2009; Hutchison et al. 2016; Sbrana et al. 2018). In this paper, we present new insights into the eruptive transitions and dynamics of a small-volume explosive-effusive trachytic eruption, using unusually well-preserved and exposed deposits on Ascension Island, South Atlantic. We combine detailed eruption stratigraphy and mapping of field relationships with analysis of individual and bulk clast textures to reconstruct transitions in eruption styles and understand their drivers and the resulting implications for future activity in this and similar settings.

\section{Geological background}

Ascension Island is an $8 \mathrm{~km}$ by $12 \mathrm{~km}$ intra-plate ocean island located $\sim 90 \mathrm{~km}$ west of the Mid-Atlantic Ridge, $7^{\circ} 56^{\prime} \mathrm{S}$ of the equator. The volcanic edifice is approximately $3800 \mathrm{~km}^{3}$ (Harris 1983), $1 \%$ of which is sub-aerial (Nielson and Sibbett 1996). Volcanism initiated $\sim 5-6 \mathrm{Ma}$ at the ridge, and the oldest subaerial rocks are $\sim 1$ Ma (Weaver et al. 1996; Jicha et al. 2013). Whereas some alkali-enriched ocean islands such as Pantelleria have a distinct "Daly Gap" (Neave et al. 2012), Ascension does not. Ascension's volcanic and plutonic rocks each record a full suite of alkali basalt-trachytic-rhyolitic compositions: explosive and effusive examples occur across the entire volcanic suite (Nielson and Sibbett 1996; Chamberlain et al. 2019). Trachytic and rhyolitic rocks are concentrated in the central felsic complex (CFC) and the Eastern Felsic Complex (EFC), where the Echo Canyon (EC) edifice is located; see maps in Figs. 1 and 2 (Nielson and Sibbett 1996; Kar et al. 1998; Chamberlain et al. 2016). This spatial restriction of silicic rocks was investigated by Chamberlain et al. (2019) and attributed to the presence of a series of nested silicic plutonic bodies in the underlying crust, which acted as a density filter stalling basalts until they evolved to lower density silica-rich compositions. Current data suggest that Ascension Island is typical of a low volume magmatic flux ocean island setting (Chamberlain et al. 2019). Here we estimate the averaged magmatic output rate (calculated from total volume of volcanic pile (Harris 1983) and age of volcanism (Weaver et al. 1996; Jicha et al. 2013)) on Ascension as approximately $0.63 \times 10^{-3} \mathrm{~km}^{3} / \mathrm{yr}$, much less than that of Hawaii, $0.426 \mathrm{~km}^{3} / \mathrm{yr}$ (Robinson and Eakins 2006). Ascension has only erupted three times in the last 5,000 years - basaltic lava flows in the N-NW of the island, two dated at $\sim 500$ years and one at $\sim 1.6 \mathrm{ka}$ using ${ }^{40} \mathrm{Ar} /{ }^{39} \mathrm{Ar}$ dating (Preece et al. 2018). In contrast, while closer in size to Ascension than Hawaii, Sao Miguel in the Azores has erupted 57 times in the last 5000 years: Sao Miguel is much younger $\sim 0.9$ Ma (Jeffery et al. 2016) - and considerably more active than Ascension. The oldest rocks on Ascension are silicic lavas from the CFC dated at $1 \mathrm{Ma}$ (Jicha et al. 2013). More than 70 explosive felsic eruptions have occurred across the CFC and EFC in the last $1 \mathrm{Myr}$ (Preece et al. 2021) but preservation is often poor; few eruptions can be traced back to a source vent (Chamberlain et al. 2016). The EFC is the younger of the two complexes (Jicha et al. 2013) and is dominated by a series of trachytic lava flows, rhyolitic domes, pumice falls 


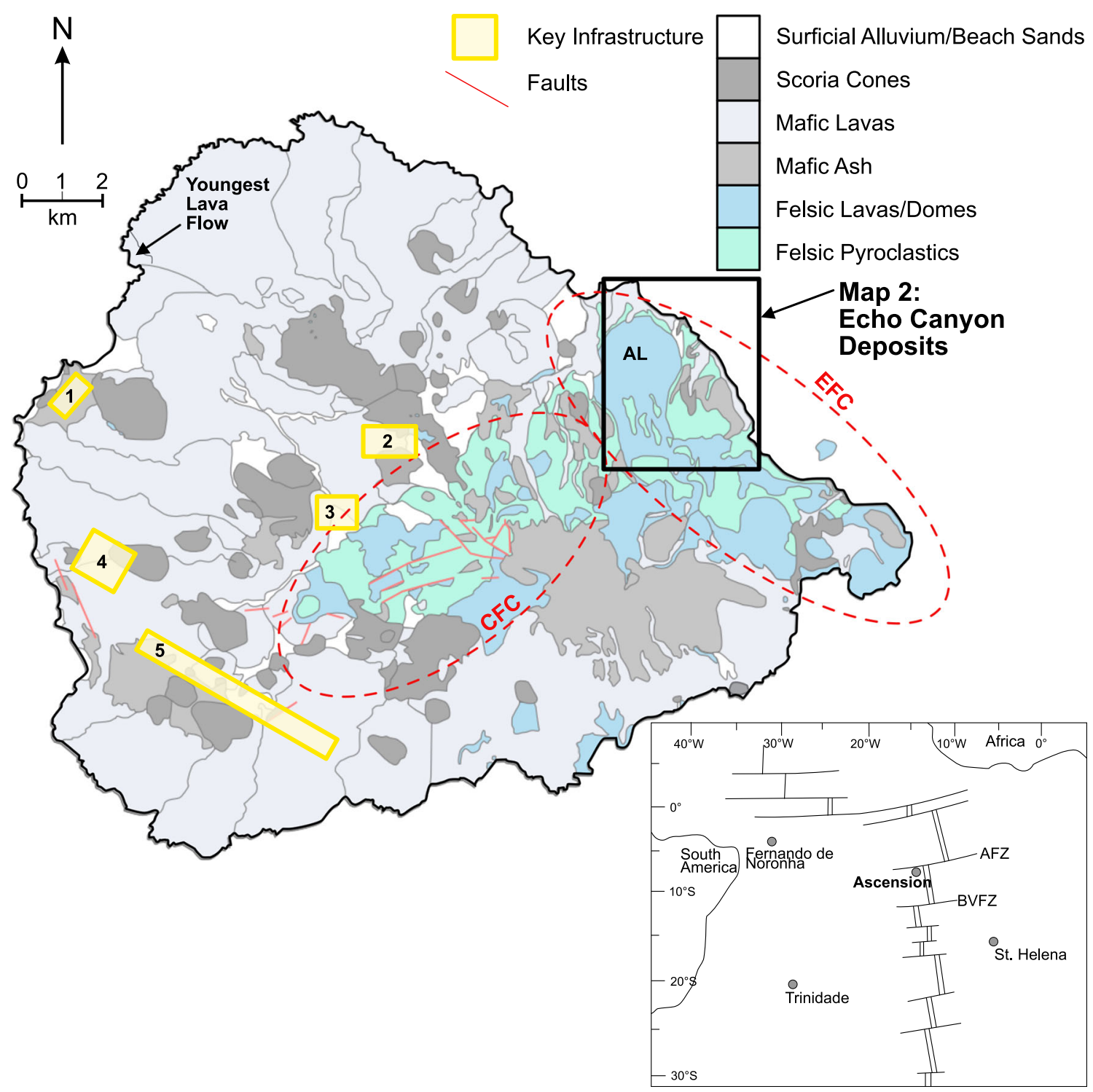

Fig. 1 Simplified geological map of Ascension Island, adapted from Chamberlain et al. (2016) showing distribution of mafic and felsic effusive and explosive products, key infrastructure and key deposits. 1 Georgetown, 2 Two Boats Village, 3 Travellers Hill Royal Air Force station, 4 US air force base, 5 Wideawake Airfield. AL, Ariane Lava

and PDC and ignimbrite deposits (Figs. 1 and 2) (Atkins et al. 1964; Nielson and Sibbett 1996; Chamberlain et al. 2016, 2019). Younger basaltic eruptions have produced several flows and scoria cones around NE-Bay.

\section{Methods}

\section{Stratigraphy and sampling}

Stratigraphy of the EC volcanic edifice was determined during two 7-week field seasons in 2018 and 2019/2020. Stratigraphic logs through eruption deposits were carried out at localities AI18- flow; EFC, Eastern felsic complex; CFC, Central Felsic Complex. Extent of EFC and CFC is denoted by dashed red ellipses. Black rectangle denotes location of Map 2. Inset: Location of Ascension Island relative to the Mid-Atlantic Ridge in the South Atlantic.

04, 22 and 23 in 2018 and AI19-02, 46 and 13 in 2019 (Fig. 2). Locations for stratigraphic logging of deposits were chosen based on exposure, accessibility and relationship to overall geometry and deposit extent. A geological map of the region (Fig. 2) was produced using data from field observations, photographs and Google Earth imagery (Google Earth 2006).

The EC edifice is divided into pumice cone and postpumice cone deposits: the pumice cone is divided into three parts, lower, middle and upper, based on lithologic characteristics. The lower, middle and upper parts of the cone were subdivided into 12 units comprising one or more beds. Each unit was distinguished from stratigraphic neighbours via either componentry and juvenile clast texture or the identification 
Fig. 2 Geological map of the Echo Canyon (EC) depositsblack box in Fig. 1. OBP is orange-brown pumice. Distal pyroclastic density current deposits (PDC) mark furthest extent of EC deposits north of the Ariane lava flow (AL). White dashed lines mark footprint of valleys EC, Echo Canyon; RC, Rainbow Canyon; and SB, Spire Beach. Geology overlaid on Google Satellite image for Ascension Island (Google Earth 2006). EC deposits are overlain by AL, which is likely sourced from Devil's Cauldron (DC).

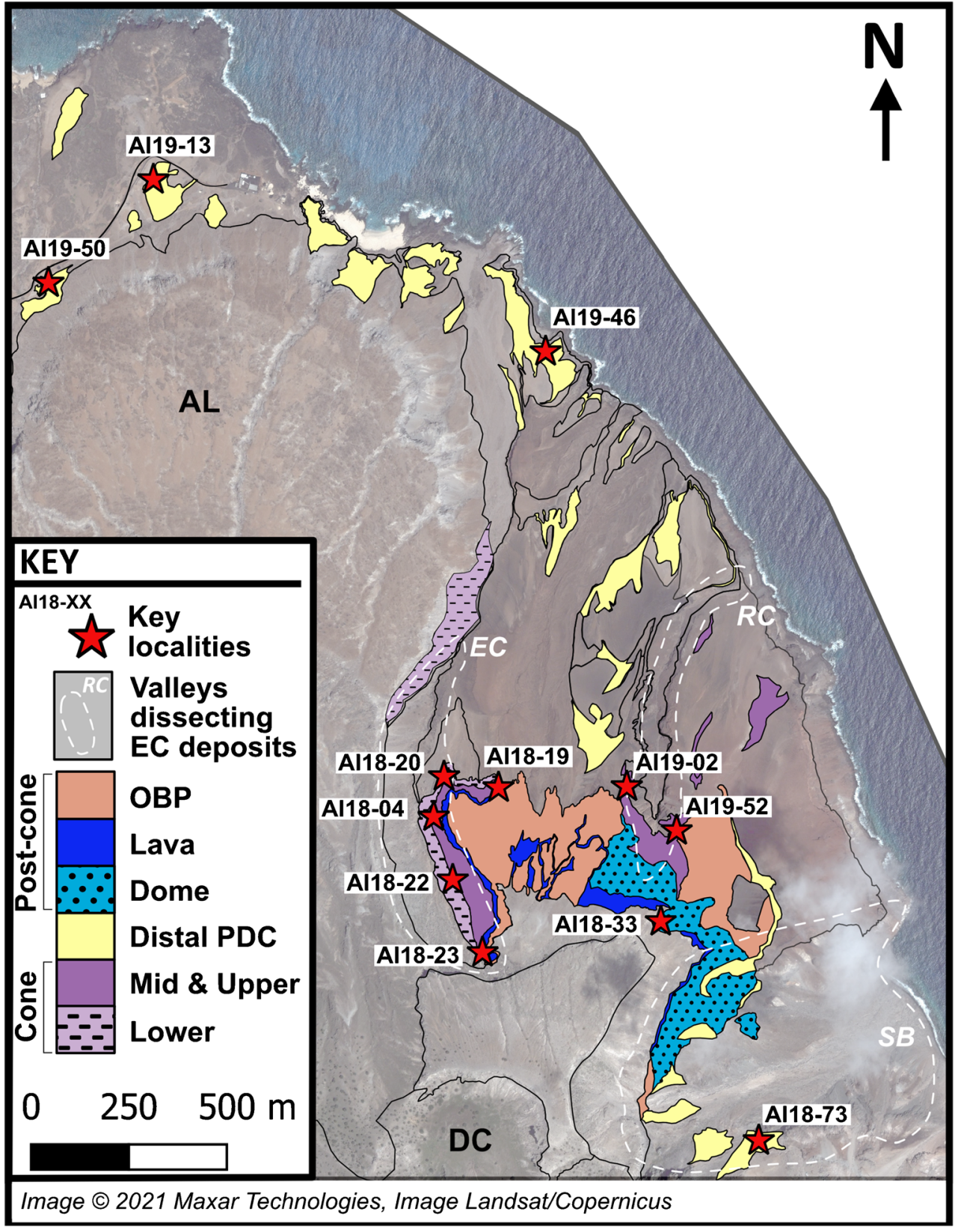

of a repeated sequence of distinct lithologic characteristics. Average maximum clast size was calculated by measuring the 5 largest clasts in outcrop and taking the average long axis. Modal clast size was qualitatively estimated in the field based on careful examination of the wider outcrop, and modal clast size values quoted henceforth are qualitative estimates only as a full grainsize study was not completed.

Six units from the pumice cone were sampled, one from each unit in the lower cone, one from the middle cone and one from the upper cone- at AI18-04, AI18-22 and AI19-02, respectively (Fig. 2). The sampling targeted each eruptive phase identified using lithologic observations. Sampling of the middle and upper cone was restricted due to outcrop accessibility in the steep cliffs of Echo Canyon and Rainbow Canyon. Bulk samples of explosive products of the cone and post-cone units containing clasts of $16-32 \mathrm{~mm}$ were collected by excavating a region up to $10 \mathrm{~cm}$ thick, extending laterally across the unit until enough material was acquired for density measurements and whole rock analyses. Samples of Units 1-4 and 9 were collected from Echo Canyon at localities AI18-04 and AI18-22, respectively. Unit 11 was sampled at AI19-52 in Rainbow Canyon, the lavas at AI18-20 and AI18-33 and the post-cone pumice fall (the orange-brown pumice, OBP) at AI18-19, as shown in Fig. 2. 


\section{Density measurements and textural categorisation}

In the laboratory, bulk samples were passed through an 8-mm sieve. Clasts in the $>8$-mm size fraction were ordered by size and each axis measured to remove clasts $>32 \mathrm{~mm}$ and $<16$ $\mathrm{mm}$. From the remaining clasts, the 100 largest were selected following Shea et al. (2010); for the OBP, all 16-32-mm clasts were selected. Clasts which have undergone significant postfragmentation textural alteration often have expanded cores and dense rims, fluidal morphologies and breadcrust exteriors (Polacci 2005). None of the clasts used in producing bulk vesicularity distributions (BVDs) exhibited breadcrust exteriors or fluidal morphologies. Clasts of the same morphology, colour and size as those selected for density measurements from each unit were broken open to check for internal textures indicative of significant postfragmentation vesicle expansion, none were found. Analysed clasts from the cone deposits lacked evidence of thermal alteration, e.g. discoloration or formation of rims, and care was taken to select the freshest looking clasts from the OBP where such discoloration was more common. Density of the 16-32-mm juvenile clasts was determined using the Archimedes principle following the suspension method detailed in Houghton and Wilson (1989) and Shea et al. (2010). For Units 1, 2, 3, 4, 6 and 11, 100 clasts were measured. For the OBP, 43 clasts were measured as the bulk sample acquired contained a high proportion of clasts $>32 \mathrm{~mm}$ diameter. Bulk vesicularity was calculated using a dense rock equivalent value of $2.51 \mathrm{~g} / \mathrm{cm}^{3}$ for Units $1-11$ and $2.55 \mathrm{~g} / \mathrm{cm}^{3}$ for the OBP. Dense rock equivalent values were calculated using the method of Lange and Carmichael (1987) from whole rock compositions attained using X-ray fluorescence (XRF) analysis (see section below for details of XRF method). Measured clasts were categorised based on pervasive vesicle textures observed in hand specimen.

\section{Geochemical analyses}

Pumice clasts and lava samples were prepared for X-ray fluorescence (XRF) analyses following Chamberlain et al. (2016). Samples were then crushed, and an aliquot of each sample milled in a tungsten carbide container before XRF analyses were carried out on a Bruker-AXS S4 Pioneer at the University of East Anglia. For major elements, analyses of multiple international standards yielded accuracies $\leq \pm$ $0.18 \mathrm{wt} \%$ when compared with certified values.

Trace element concentrations were measured by ICP-mass spectrometry after $\mathrm{HNO} 3+\mathrm{HF}$ digestion of $0.1000 \mathrm{~g}$ of sample powder at $\sim 180^{\circ} \mathrm{C}$ and $200 \mathrm{psi}$ for $30 \mathrm{~min}$, evaporation to dryness and dissolution in $100 \mathrm{ml}$ of $4 \mathrm{vol} . \% \mathrm{HNO}_{3}$. Measurements were done with a PE SCIEX ELAN-5000 spectrometer (rhodium internal standard). Precision, as determined from international standards, was better than $\pm 2 \%$ and $\pm 5 \%$ for concentrations of 50 and $5 \mathrm{ppm}$, respectively. Raw major and trace element data are given in the supplementary data.

\section{Deposits and products of the Echo Canyon eruption}

The EC eruption deposits have an ${ }^{40} \mathrm{Ar} /{ }^{39} \mathrm{Ar}$ age of $59 \pm 4 \mathrm{ka}$ (Preece et al. 2021), crop out over $\sim 3.4 \mathrm{~km}^{2}$ and consist of a partially preserved and exposed proximal pumice cone, pumice fall deposits, a lava dome and a brecciated lava (Figs. 2, 3 and 4). There is no evidence for a significant time break between the EC deposits (e.g. paleosols or erosional surfaces), and additionally, all the eruption products have a unique phenocryst population; we therefore consider them to be products of a single eruption. The EC phenocryst population comprises 3-8-mm diameter feldspar and clinopyroxene macrocrysts (Appendix 2). Pumice clasts typically contain $<3 \%$ feldspar microlites from $<10$ to $750 \mu \mathrm{m}$, with the exception of some clasts within the uppermost pumice fall (see below and Appendix 2 Fig. 22). The geometry of the volcanic edifice, apparently elongated towards NW, results from both the paleo-topography and prevailing wind direction (Fig. 5). The pumice cone has a maximum preserved thickness of $50 \mathrm{~m}$ (Fig. 4A), and it thins rapidly to the E-SE (Fig. 4A) and WNW (Fig. 5B and C). Juvenile clast descriptions are given in Fig. 6 and Appendix 1 Fig. 13, and stratigraphic and geometric relationships between the EC deposits are shown in Figs. 2, 3, 4 and 5. Generalised descriptions and interpretations of the EC deposits are given below and in Figs. 7 and 8. Full stratigraphic and petrographic descriptions of the EC deposits are given in Appendices 1 and 2.

\section{Pumice cone stratigraphy}

The pumice cone is here divided into three parts: the lower, middle and upper cone. The lower cone is composed of massive, clast-supported pumice fall deposits (Units 1-4, Fig. 7A and B and Fig. 8) and is subdivided into 4 units (Appendix 1), one of which contains three thin ash beds (Fig. 7A and C). The juvenile material varies up through the lower cone: lower units are characterised by micro- and macro-vesicular pumice with equant vesicles; sheared pumice clasts are most abundant in Unit 3 and dense clasts most abundant in Unit 4 (Figs. 6 and 8). A conspicuous layer of lithic clasts containing syenite and granite blocks marks the boundary between Units 3 and 4 .

The middle cone is more heterogeneous than the lower cone Fig. 8 and comprises interbedded matrix- and clastsupported beds (Units 5-10, Fig. 7D) of variable grainsize. Clast-supported beds contain angular pumice clasts, whereas the matrix-supported beds contain rounded pumice clasts. These are interpreted as pumice fall deposits and PDC deposits, respectively. Juvenile clasts are dense (Fig. 6). Erosional surfaces have not been observed between units of the lower and middle cone.

The upper cone comprises a sequence of matrix- and clastsupported PDC deposits containing sub-angular to rounded 
Distal Deposits

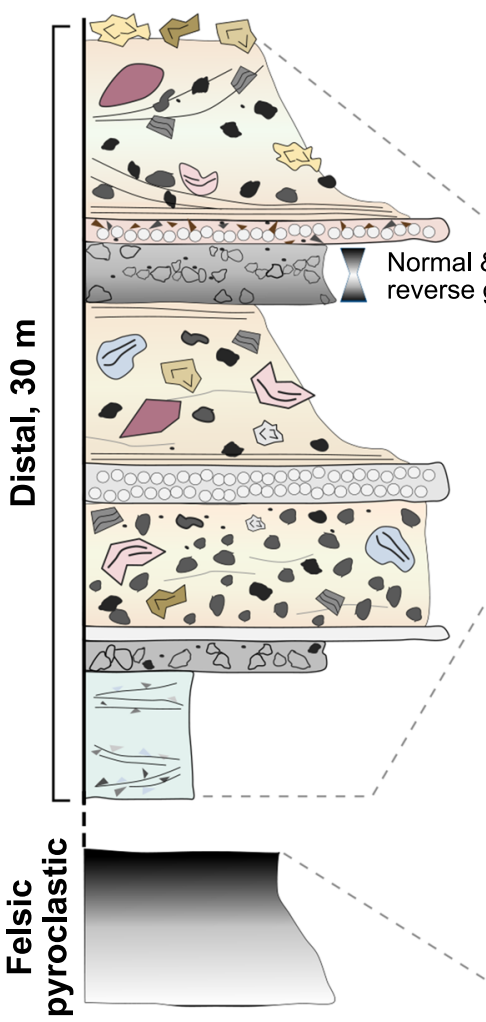

Generalised Full Sequence

Ultra-proximal

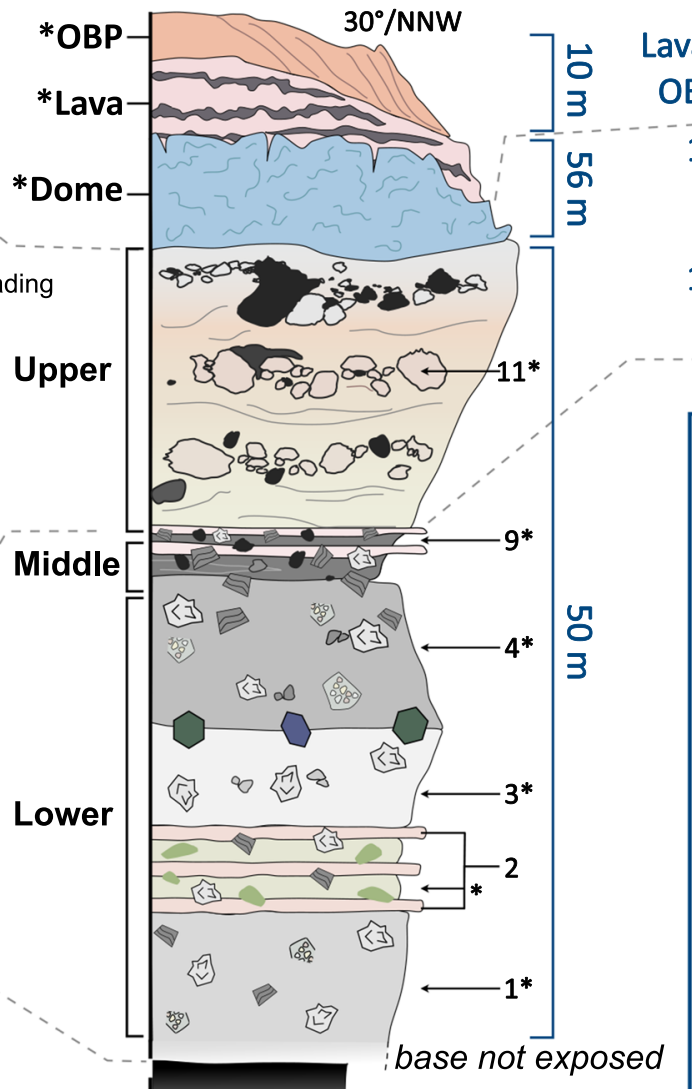

Lapilli Tuff

Variably vesicular lava - pumice (trachyte)

Obsidian/ obsidian breccia

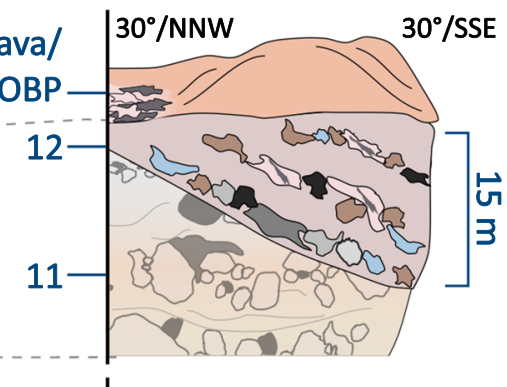

I

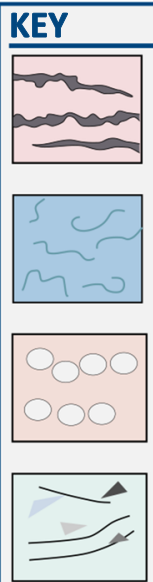

Lava

Dome

Accretionary

lapilli in ash

Fine-grained angular fragments, $x$-strat

Indurated ash-rich beds

Angular, banded bombs

Bread crust bombs

Rounded pumice, ash supported
Fig. 3 Composite log of the Echo Canyon (EC) eruption deposits. Beds represented by a solid fill are clast-supported; beds with a gradient fill are variably matrix and clast supported as detailed in Appendix 1. Dashed grey lines indicate stratigraphic relationships between distal, generalised sequence and ultra-proximal deposits. Dashed black lines indicate contact

pumice clasts (Unit 11, Figs. 3, 4E and 7E and G). Juvenile clast textures are summarised in Fig. 6 and Appendix 1, Fig. 14 and abundances of types 1-5 displayed in Fig. 8. The upper cone is distinguished by the appearance of obsidian and obsidian breccia clasts (Appendix 1, Fig. 14) that constitute $10 \%$ of the unit. Distal outcrops of Unit 11 occur at distances of $2 \mathrm{~km}$ from the cone and reach $\sim 30 \mathrm{~m}$ thick. The uppermost unit in the cone (Unit 12) is a coarse-grained clast-supported, proximal fall deposit composed of pumice, spatter-some of which exceed $70 \mathrm{~cm}$ in diameter - and dense juvenile clasts that closely resemble the overlying lava flow. Unit 12 drapes not always exposed. Clast types and key bed characteristics are detailed in the key. Unit numbers as referred to in text are marked in black; asterisks indicate sampled units. Maximum exposed thickness of cone deposits is $50 \mathrm{~m}$.

an unconformity on top of the PDC deposits of the upper cone and some of the middle cone, a possible result of erosion by PDCs that did not leave any deposits, or collapse, reflecting the proximity of the likely vent to this location.

\section{Post-cone lavas and pumice fall}

Two trachytic lavas post-date the pumice cone. The lower lava is a $30-40-\mathrm{m}$-thick, variably altered and brecciated trachyte lava dome, 3-4 times thicker than the overlying lava (see Figs. 2, 4B and 5B-D). It contains distinctive 3-8-mm feldspar and 


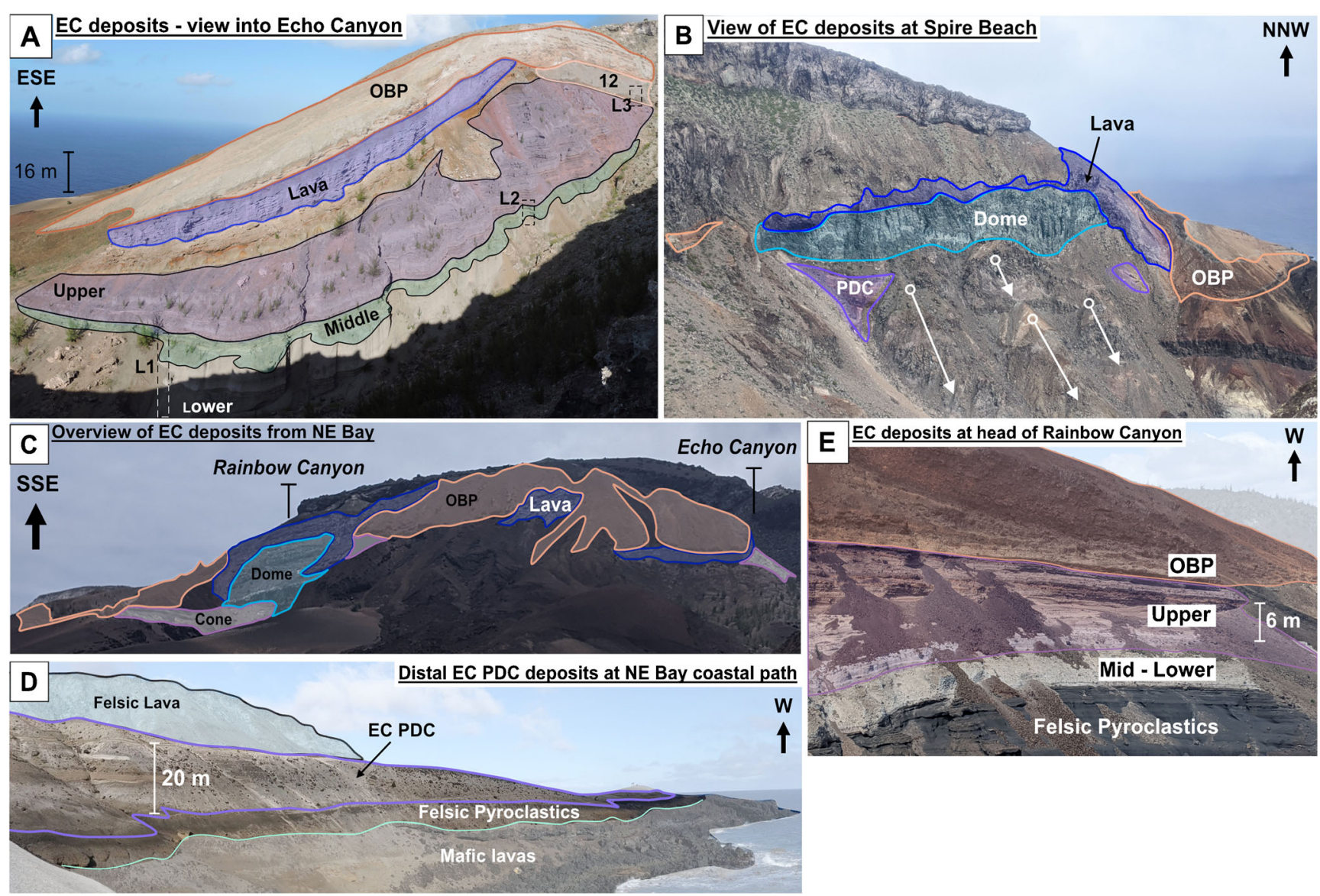

Fig. 4 Overview photos of Echo Canyon (EC) eruption deposits. A View into Echo Canyon showing dissected cone, relates to Fig. 5a box 1. Black dashed boxes L1, L2 and L3 show logged sections. Lower, middle and upper cone, Unit 12 and orange-brown pumice (OBP) correspond to Fig. 3. B section at Spire Beach (see Fig. 5D), white arrows from circles show slump directions, with distal pyroclastic density current deposits (PDC), the dome, lava and OBP indicated by shaded outlined regions. $\mathbf{C}$ View of
EC deposits looking SSE from NE Bay coastal path. Valleys EC and Rainbow Canyon (RC) are marked. D Relationship between distal PDC deposits of EC eruption, felsic pyroclastics and coastal lavas, taken from the NE-Bay lower coastal path. E View into western face of RC showing relationships between the OBP, cone deposits and felsic pyroclastics. EC Units logged at 6-m scale bar location.

clinopyroxene macrocrysts (3-5\%) often associated with vesicles up to $1 \mathrm{~cm}$. Groundmass crystallinity is heterogeneous in thin section with regions up to $70 \%$ feldspar microlites. The overlying lava is a $7.5-10-\mathrm{m}$-thick brecciated porphyritic trachyte lava flow of similar composition to the older lava but with lower overall groundmass crystallinity - up to $30 \%$ feldspar microlites. Feldspar and clinopyroxene macrocrysts comprise $3-5 \%$ of the lava. The lava has a vesicularity of up to 10 percent, with vesicle diameters up to $0.5 \mathrm{~cm}$. Sub-parallel, discontinuous layering is defined by lenses of un-altered lava and brecciated regions altered to clays. The uppermost unit, the OBP, is a massive, coarse-grained, clast-supported pumice fall deposit that thickens from 3 to $10 \mathrm{~m}$ over $450 \mathrm{~m}$ from the top of the cliff above AI1 8-04 towards the SE to locality AI1823 and mantles underlying topography (Figs. 3, 4A, C, E and $5 \mathrm{a}, \mathrm{c}, \mathrm{d})$. It is composed of angular pumice $(\sim 95 \mathrm{vol} . \%)$ and obsidian ( $\sim 5$ vol. \%) lapilli and blocks (Fig. $7 \mathrm{~K})$. In thin section, pumice clasts contain discrete microlite-rich regions within homogenous glass (Appendix 2, petrography).

\section{Vesicularity and vesicle texture variations}

Bulk vesicularity distributions (BVDs) and the abundance of each textural type (Fig. 6) in the pumice population of each sampled unit are displayed relative to their stratigraphic position in Fig. 8.

From Units 1-3, BVDs progressively narrow about a mode of 75-80\%. Clasts in Units 1 and 2 are both dominated by macrovesicular equant vesicles, and $<5 \%$ are sheared. In Unit 3, 31\% of clasts are sheared, and the BVD is the narrowest of all the units. Whereas Unit 4 has similar lithologic characteristics to Unit 3, the pumice population is texturally distinct, and the BVD is broader: $64 \%$ of clasts fall outside the modal range $-70-75 \%$. The proportion of dense clasts increases by $24 \%$, and sheared and microvesicular equant clast abundance is halved.

The abundance of dense clasts peaks at $36 \%$ in Unit 9. Vesicle texture heterogeneity is reflected in the BVD, which is broad with $37 \%$ of clasts with a vesicularity lower than $65 \%$, compared to none in Unit 3. In Unit 11, the five textural types are more evenly represented and the BVD narrower than 


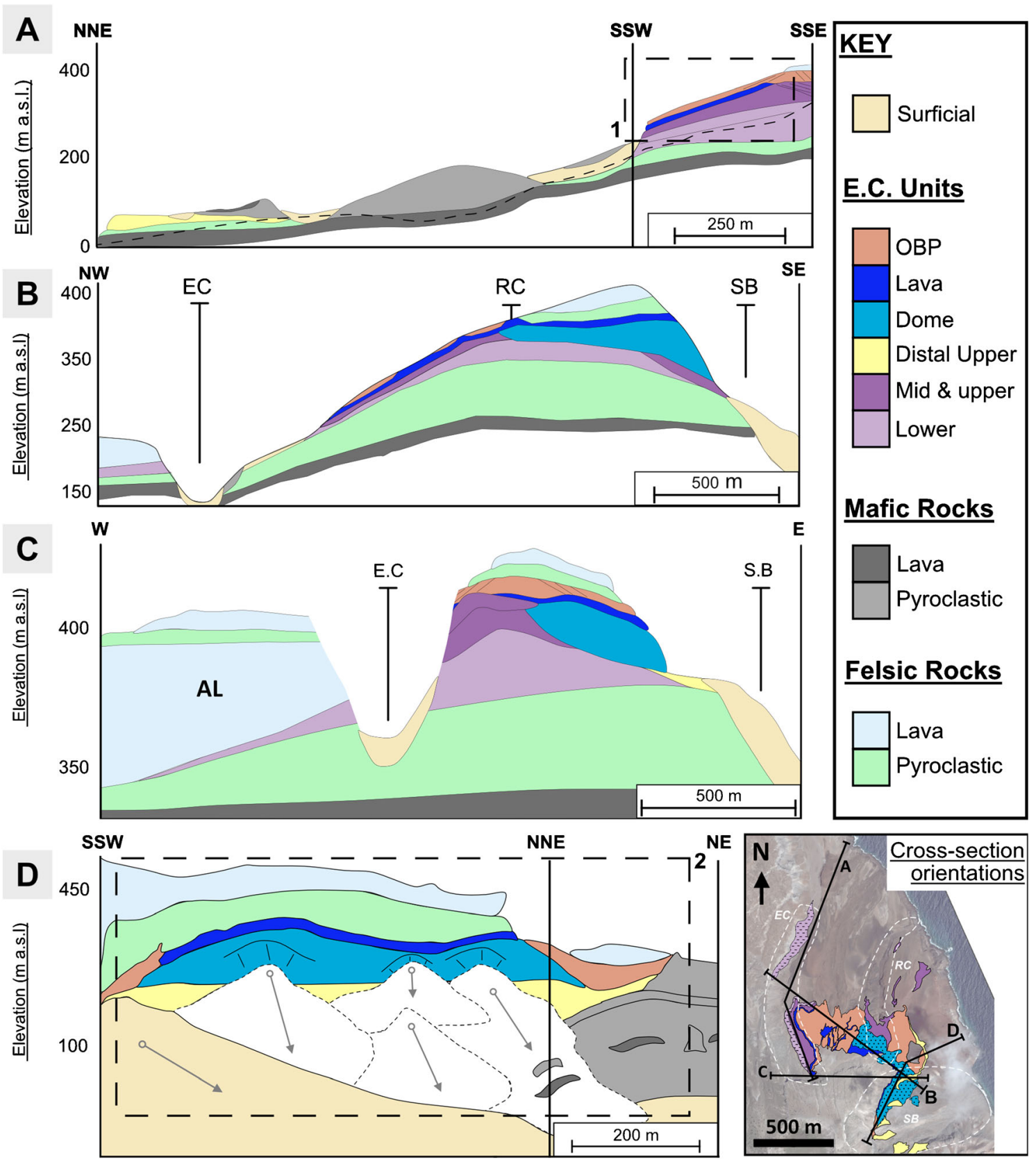

Fig. 5 Interpretive cross-sections through the Echo Canyon (EC) eruption deposits corresponding to lines of sections A-D on inset. OBP is orange-brown pumice; "upper", "mid" and "lower" refer to lower, middle and upper cone from Fig. 3. A Section down Echo Canyon to the coast with underlying felsic pyroclastics and mafic lavas projected below the land surface (dashed black line). B Section from EC to Spire Beach (SB) shows rapid thinning of pumice cone deposits; locations of the three canyons that cut the EC deposits are marked; Rainbow Canyon

Unit 9; modal vesicularity is 70-75\%. The proportion of dense clasts is $22 \%$ lower than in Unit 9 , but $43 \%$ of clasts are sheared. In the OBP, modal vesicularity increases and broadens to $70-80 \%$, and $16 \%$ of clasts have a vesicularity of $<65 \%$. Less than $10 \%$ of clasts are sheared, and $23 \%$ are dense.
(RC), EC and SB. C Approximated more proximal section W-E showing dome to the east and thinning of cone stratigraphy beneath the Ariane Lava (AL) to the west. D Spire Beach section showing how OBP mantles pyroclastic density current (PDC) deposits, lava and dome. Debris falls outlined in grey dashed lines with arrows showing direction of motion. Inset map: shows orientations of cross-sections with EC deposits annotated onto satellite imagery of NE-Bay from Google Earth. Dashed lines denote extent of key valleys dissecting EC deposits, EC, RC and SB.

\section{Whole rock compositions and viscosity}

Whole-rock compositions of bulk samples from representative units are shown in Fig. 9. All juvenile material is trachytic: between Units 1 and $9, \mathrm{~K}_{2} \mathrm{O}+\mathrm{Na}_{2} \mathrm{O}$ variation is $<0.5 \mathrm{wt} \%$ and $\mathrm{SiO}_{2}<1 \mathrm{wt} \%$. The lavas are $\sim 3 \mathrm{wt} \%$ poorer in silica with 
Fig. 6 Description of five pumice clast textural types identified in the Echo Canyon deposits. H.S. indicates in hand specimen, // is parallel to elongation orientation, $\perp$ indicates perpendicular to elongation direction.

Superscripts: ${ }^{1}$ Bulk vesicularity as measured from at least 100 clasts of each textural group. Black scale bars represent $1 \mathrm{~cm}$. Red boxes 1-5 are backscattered electron images of representative vesicle textures from each identified pumice type, boxes are $1 \mathrm{~mm}^{2}$. SEM images $1-4$ are collected on a FEI Quanta 650 FEG at the Natural History Museum, London, UK, and image 5 collected on a Zeiss Gemini sigma $300 \mathrm{VP}$ at the Zeiss facility in Cambridge, UK (see Appendix 3 for method outlining rationale for clast selection).

\begin{tabular}{|c|c|c|c|c|c|}
\hline & Vesicle Texture & Appearance & Bulk Ves. ${ }^{1}$ & \\
\hline \multirow{5}{*}{ 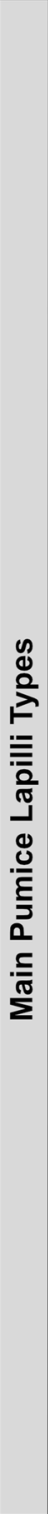 } & Type 1 & $\begin{array}{l}\text { Micro-vesicular, } \\
\text { equant } \\
\text { Sub-spherical - } \\
\text { colloform vesicles } \\
\text { rare. } \\
<5 \% \text { vesicles in } \\
\text { H.S. > } 1 \mathrm{~mm}\end{array}$ & $\begin{array}{l}\text { Pale grey } \\
\text { Angular } \\
\text { Friable }\end{array}$ & $\begin{array}{l}\text { Modal: } \\
75-79 \% \\
\text { Range: } \\
55-84 \%\end{array}$ & \\
\hline & Type 2 & $\begin{array}{l}\text { Macro-vesicular, } \\
\text { equant } \\
\text { Sub-spherical - } \\
\text { colloform vesicles. } \\
30 \% \text { vesicles in } \\
\text { H.S. }>0.1 \mathrm{~cm} \\
<5 \% \text { are }>2 \mathrm{~cm}\end{array}$ & $\begin{array}{l}\text { Pale grey - white } \\
\text { Angular } \\
\text { Foam-like } \\
\text { Friable }\end{array}$ & $\begin{array}{l}\text { Modal: } \\
80-84 \% \\
\text { Range: } \\
64-92 \%\end{array}$ & \\
\hline & Type 3 & $\begin{array}{l}\text { Micro-vesicular, } \\
\text { elongate } \\
\text { Elongate - tube } \\
\text { vesicle networks. } \\
\text { Dominantly } \\
<1 \mathrm{~mm} \\
\text { Approx. } 5 \% \\
>1 \mathrm{~mm}\end{array}$ & $\begin{array}{l}\text { Mid-grey, angular } \\
\text { Not easily friable } \\
\text { Some mm-scale } \\
\text { banding } \\
/ / \text { vs } \perp \text { elongation } \\
=\text { glassy vs } \\
\text { saccharoidal } \\
\text { texture. }\end{array}$ & $\begin{array}{l}\text { Modal: } \\
75-79 \% \\
\text { Range: } \\
58-83 \%\end{array}$ & \\
\hline & Type 4 & $\begin{array}{l}\text { Macro-vesicular, } \\
\text { elongate } \\
\text { Elongate - tube } \\
\text { vesicle networks. } \\
\text { H.S. many > } 1 \mathrm{~mm} \\
\text { Max vesicle } \\
\text { diameter: } 1.5 \mathrm{~cm}\end{array}$ & $\begin{array}{l}\text { Pale grey, angular } \\
\text { Not easily friable } \\
\text { Some mm-scale } \\
\text { banding } \\
/ / \text { vs } \perp \text { elongation } \\
=\text { glassy vs } \\
\text { saccharoidal } \\
\text { texture. }\end{array}$ & $\begin{array}{l}\text { Modal: } \\
74-79 \% \\
\text { Range: } \\
58-82 \%\end{array}$ & \\
\hline & Type 5 & $\begin{array}{l}\text { Dense } \\
\text { Range of rounded } \\
\& \text { complex } \\
\text { sheared networks } \\
\text { Few vesicles } \\
\text { visible in } H . S . \\
\text { Visible vesicles } \\
\text { mostly }<1 \mathrm{~mm}\end{array}$ & $\begin{array}{l}\text { Dark grey } \\
\text { Angular } \\
\text { Dark, mm-scale } \\
\text { banding common } \\
\text { Not easily friable }\end{array}$ & $\begin{array}{l}\text { Modal: } \\
60-70 \% \\
\text { Range: } \\
49-84 \%\end{array}$ & \\
\hline
\end{tabular}

the same range in alkalis. The overlying OBP composition sits between the lavas and the cone pumices. There was no significant difference in composition between textural groups from the same unit (see supplementary data). All the EC units have a peralkalinity index (PI) of 1-1.04 [PI = Molar $\left(\mathrm{Na}_{2} \mathrm{O}+\right.$ $\left.\mathrm{K}_{2} \mathrm{O}\right) / \mathrm{Al}_{2} \mathrm{O}_{3}$ ]. Generally, major and trace element data for the proximal cone pumices reflect a slightly more evolved composition. Cone units have lower $\mathrm{Al}_{2} \mathrm{O}_{3}, \mathrm{MgO}, \mathrm{Sr}, \mathrm{Eu}$ and $\mathrm{Ba}$ than the post cone units; see Fig. 9. Proximal cone pumices have $\mathrm{Zr}$ concentrations $>1080 \mathrm{ppm}$, whereas the lava, dome and OBP have $\mathrm{Zr}$ concentrations $<900 \mathrm{ppm}$.

Whole-rock major element data was used to calculate estimated melt viscosity across a range of $\mathrm{H}_{2} \mathrm{O}$ concentrations (Table 2). Samples are only mildly peralkaline so the model of Giordano et al. (2008) was applied. For comparison, calculated viscosities of a typical calc-alkaline basalt, dacite and rhyolite from Le Maitre (1976) and peralkaline rhyolite from Clarke (2020) are orders of magnitude higher (Table 2).

Several previous studies indicate Ascension Island magmas are wet: $2-4 \mathrm{wt} \%$ for a trachyte and $8 \mathrm{wt} \%$ for a mingled basalt-rhyolite scoria-pumice fall (Kar et al. 1998; Chamberlain et al. 2016, 2019, 2020). We do not currently have volatile data for the EC eruption much less, volatile contents captured in different erupted glasses. So we have calculated here the melt viscosity of four sampled EC units across a range of volatile concentrations. At $4 \mathrm{wt} \%$ (representing a likely pre-eruptive water content), EC melt viscosity of the four sampled units ranges from $10^{3.3}-10^{3.6}$ Pas at a reasonable 
Fig. 7 A-C Lower pumice, pumice falls. A Units 1-4 of the Echo Canyon deposit (EC). B General characteristics of clastsupported pumice falls and $\mathbf{C}$ ash beds of Unit 2. D Middle Cone, transition zone, with varying clast size and ash content of Unit 6 . $\mathbf{E}$ Upper cone units above log site (L2 in Fig. 4) showing lower part of proximal pyroclastic density current (PDC) deposits in EC. F Stratified and massive PDC deposits at Rainbow Canyon (RC), tool $30 \mathrm{~cm}$ for scale. $\mathbf{G}$ Obsidian deformed around pumice clasts in stratified PDC deposits at RC. H Lava and pumice clasts in Unit 12, hammer $30 \mathrm{~cm}$ for scale. I Upper part of Unit 12 , highly altered. J Brecciated lava, fresh parts are dark, altered are pale pink. $\mathbf{K}$ Obsidian bomb within the orange-brown pumice (OBP).
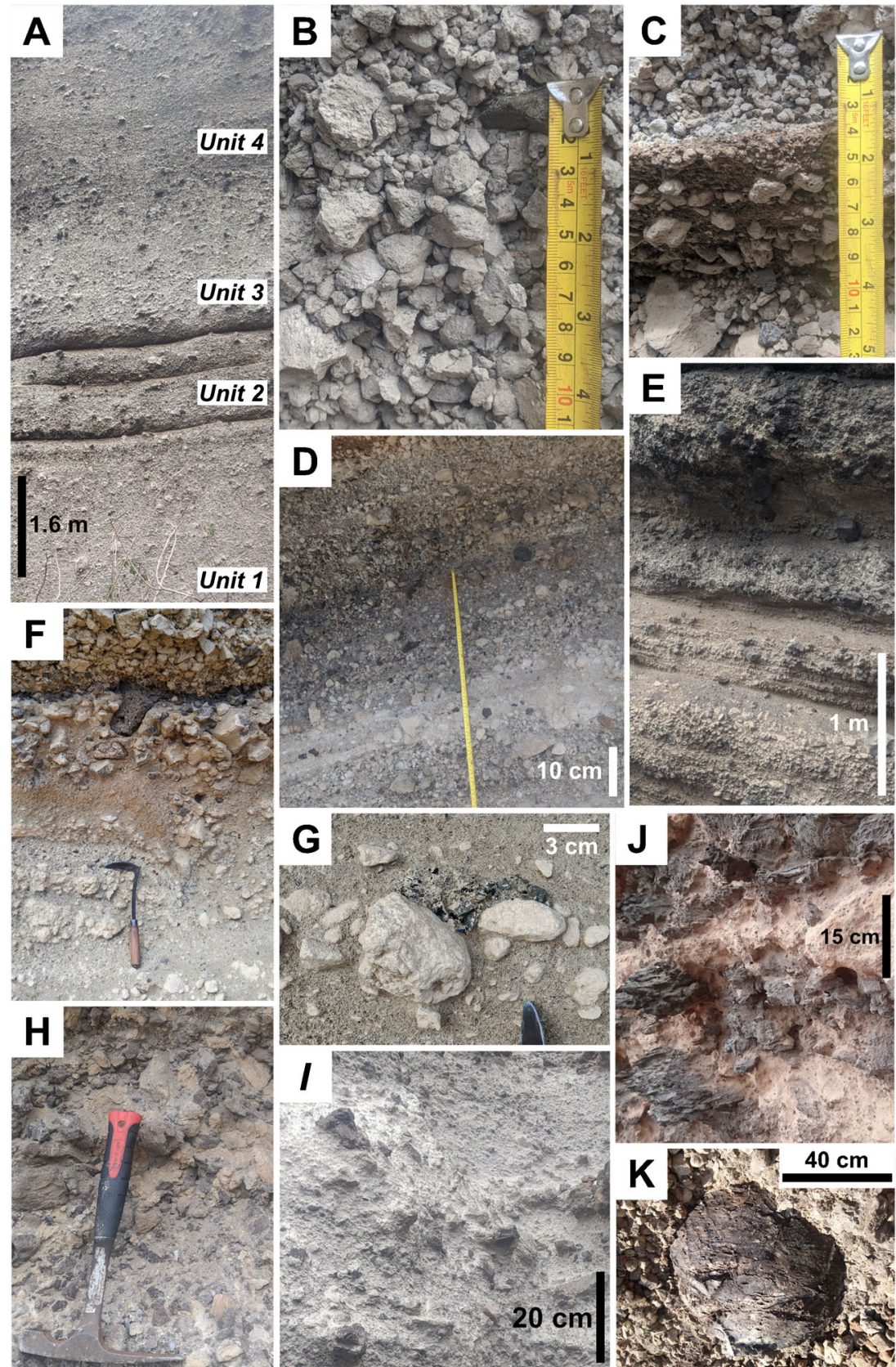

eruptive temperature of $900^{\circ} \mathrm{C}$. This is only one order of magnitude greater than a basalt erupting at $1000^{\circ} \mathrm{C}$ with $1 \mathrm{wt} \%$ water (Table 2), but with lower water contents or following degassing, viscosity would rise; our calculations demonstrate that this is highly unlikely even then to generate melt with viscosities equivalent to normal rhyolite.

\section{Discussion}

Stratigraphy, juvenile clast textures and bulk vesicularity distributions (BVDs) are discussed below and used to interpret eruption dynamics, place constraints on explosivity and understand the influence of magma composition on the progression of the EC eruption.

\section{Stratigraphy and eruptive style}

The EC eruption shows multiple transitions in eruptive style: initial violent Strombolian-sub-Plinian activity progressed to a stable Plinian column (lower cone), which underwent transient collapse forming PDCs (middle and upper cone). An effusive phase followed (lava and dome), before a final, short-lived explosive phase (OBP). The deposits are linked 


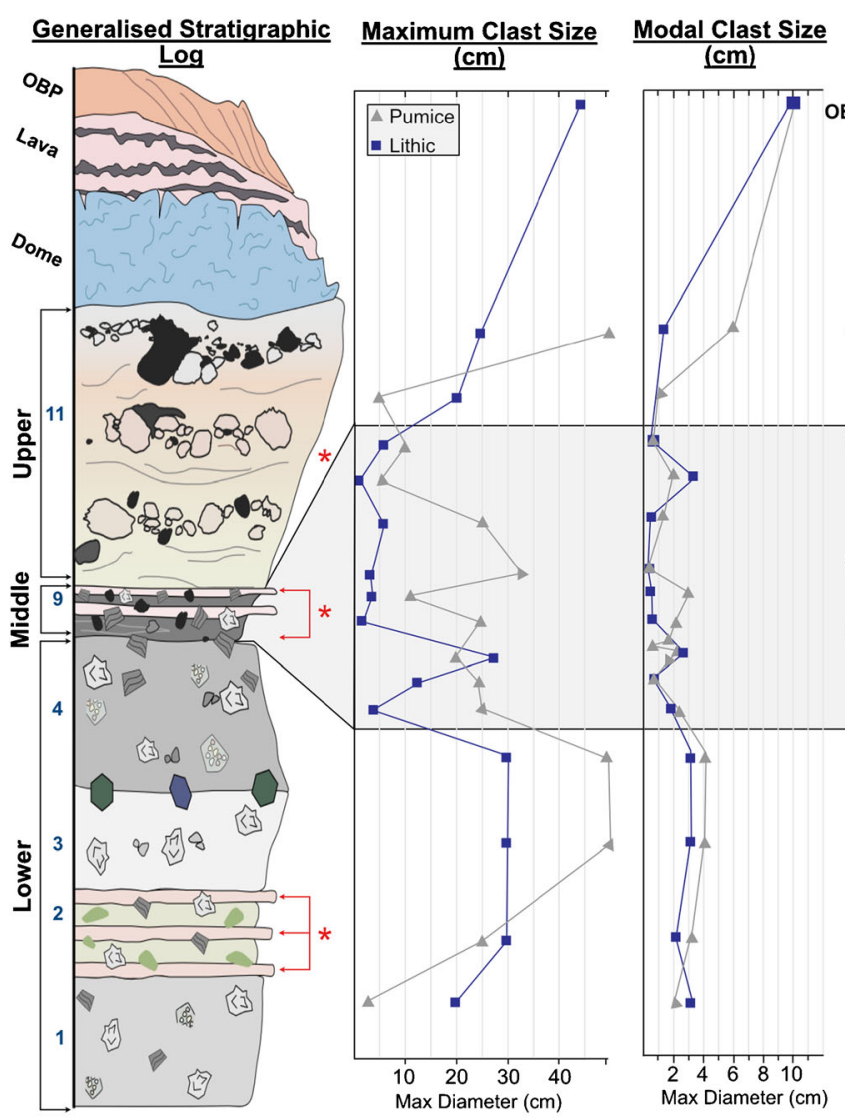

Fig. 8 Generalised vertical section from Fig. 3, red arrows and asterisks mark stratigraphic locations where fine ash was identified in outcrop; the ash beds of Unit 2, Units 5-10 of the middle cone and Unit 11. Maximum and modal lithic and pumice clast data estimated in the field are shown. The grey-shaded region represents data for beds in Units 5-10. Estimated modal and average maximum lithic and clast size are smallest in middle and upper cone units. Lithic clast proportions increase in middle and upper units relative to the lower cone. Bulk vesicularity distributions for

to a single eruptive period through the absence of erosional surfaces between explosive and effusive phases, deposit geometry and the presence of a distinct phenocryst population not seen in other Ascension Island deposits (Appendix 2). The slightly less evolved compositions of the post-cone units may reflect slight compositional zonation of the magma storage region resulting in initial eruption of lower density, more evolved compositions as is often seen for trachytic melts (Chamberlain et al. 2016; Jeffery et al. 2018).

Cone deposit similarities in estimated modal lithic and pumice clast size, within each unit and abundance of pumice and lithic clasts $>64 \mathrm{~mm}$, indicates they are proximal (cf., Cas and Wright 1996). Deposits thin rapidly, lack matrix and have modal bulk vesicularity $>70 \%$. Characteristics of Units 1 and 2 indicate proximal air fall, similar to Strombolian pumice cones described by Houghton et al. (1985) on Mayor Island, New Zealand (Table 1). The thickness, lack of stratification and low lithic clast abundance in Units 3 and 4 reflect progression to an established, stable plume with little input of conduit material (cf., Cioni et al. 2008,
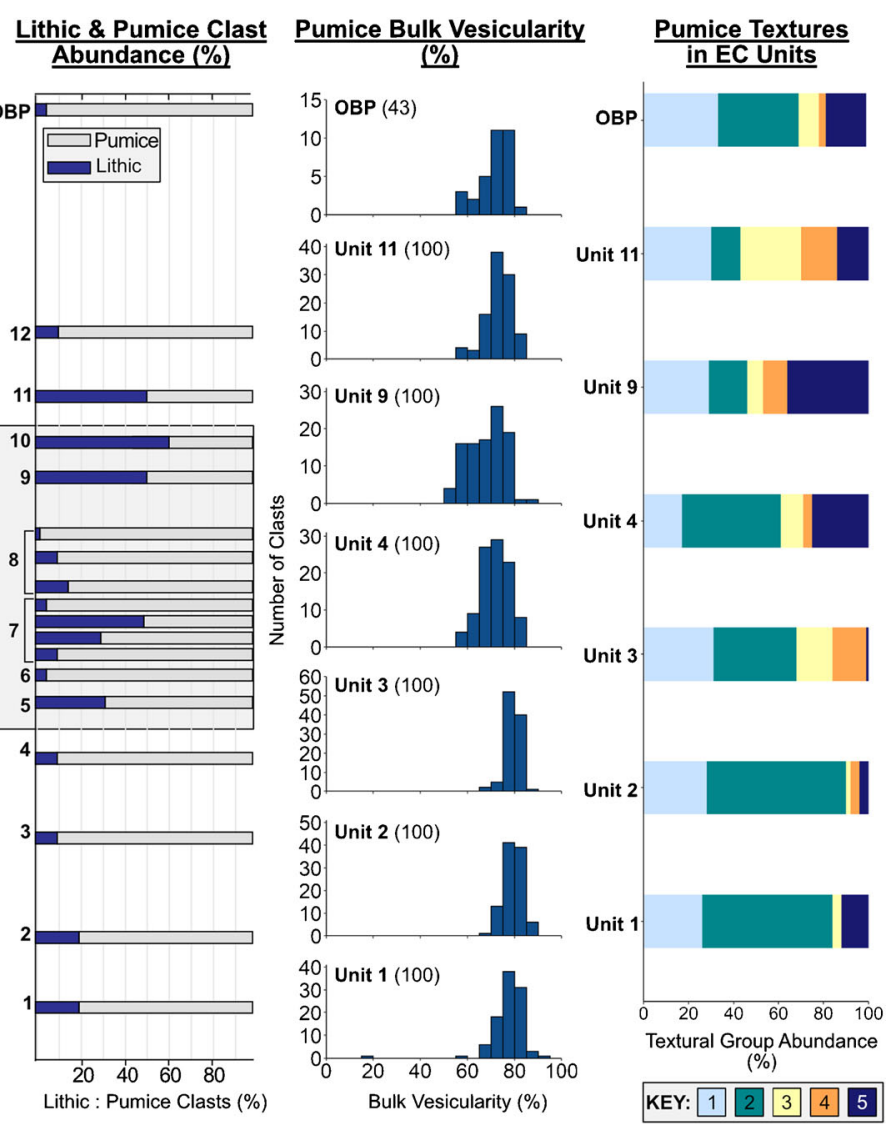

each sampled unit are presented, and the number of clasts analysed for each unit is quoted in brackets next to the unit number/name. Abundance of pumice clast textures are displayed as a percentage of analysed clasts for each Unit. Numbers $1-5$ in the key correspond to the five main textural types identified: type 1 , micro-vesicular equant; type 2 , macrovesicular equant; type 3 , micro-vesicular elongate; type 4 , macrovesicular elongate; type 5 , dense.

2015). Conversely, the graded boundary between the lower and middle cone suggests waning eruption intensity and increased column instability, often associated with pulsatory sub-plinian activity (Cioni et al. 2015; Andrews et al. 2018). Thin, interbedded units in the middle cone containing angular clasts and high proportions of lithic fragments record short-lived convective plumes (cf., Cioni et al. 2008; Scott et al. 1996; Houghton et al. 2004) during the transition to the main PDC-forming phase. In the upper cone, the dominance of metres thick, stratified ash rich beds containing lenses of pumice clasts records a significant phase of partial/total column collapse which generated PDCs (cf., Scott et al. 1996; Cole et al. 1999; Houghton et al. 2004; Cioni et al. 2008; Andrews et al. 2018). Obsidian and obsidian breccia clasts record fragmentation of accumulations of degassed melt on the conduit walls and formation of tuffisite veins - an additional degassing pathway (Heap et al. 2019).

A transition to effusive activity produced a dome and brecciated lava with groundmass crystallinities of $30-70 \%$ and 

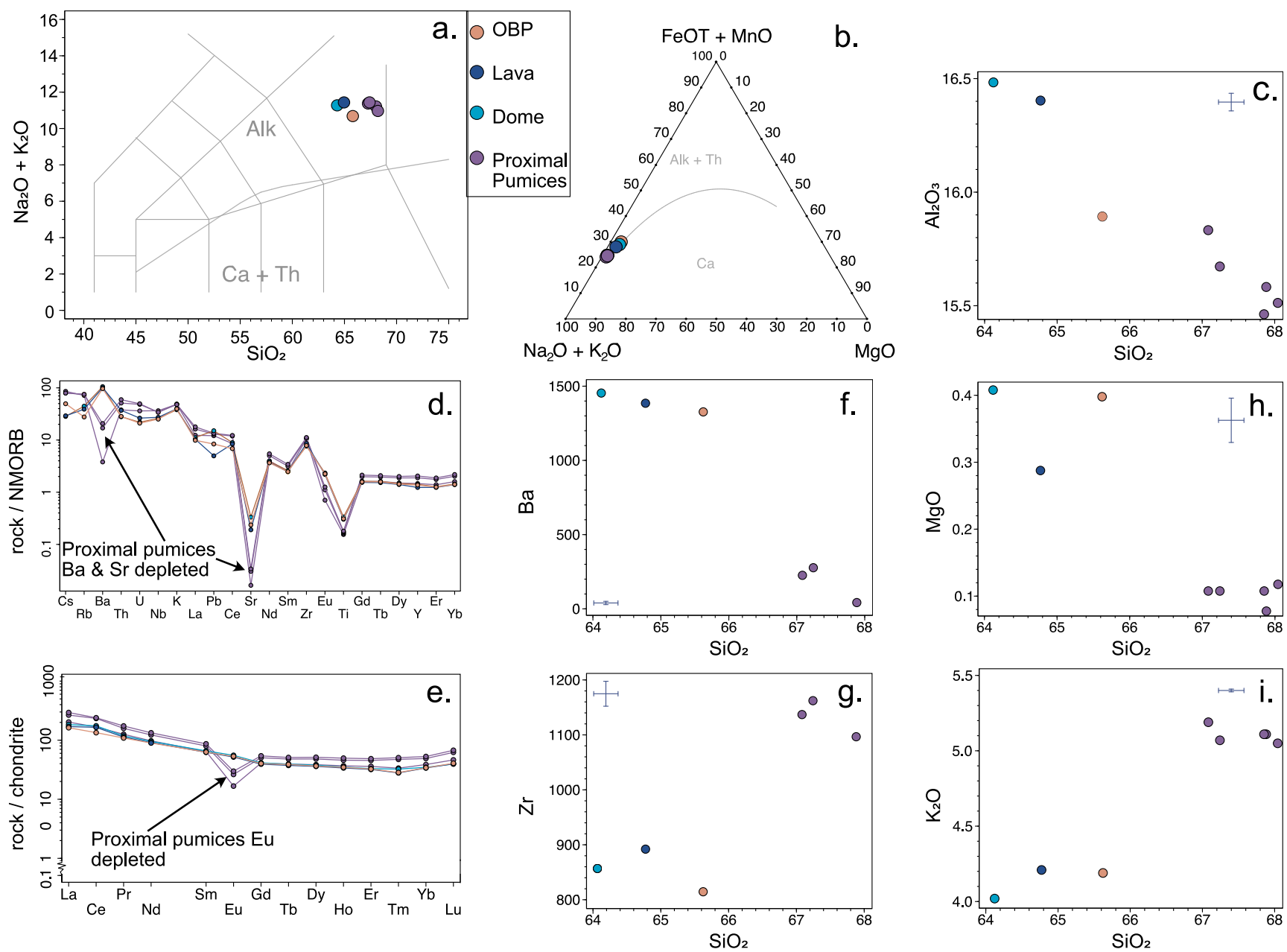

Fig. 9 Whole-rock major and trace element data of pumice and lavas from the Echo Canyon (EC) deposits. Proximal pumices are from the lower-upper cone. In C, F, G, H and I, blue crosses represent maximum analytical error for each element, \pm 0.18 for $\mathrm{SiO}_{2}, \pm 0.03$ for $\mathrm{MgO}, \pm 0.04$ for $\mathrm{Al}_{2} \mathrm{O}_{3}$ and \pm 0.1 for $\mathrm{K}_{2} \mathrm{O}$. A Total alkalis-silica diagram showing EC deposits plot in the trachyte field with proximal pumices slightly more evolved than the lavas and orange-brown pumice (OBP), symbols are larger than analytical error. B Ternary plot of total $\mathrm{Fe}+\mathrm{MnO}$ against $\mathrm{MgO}$ and total alkalis. Calc-alkaline (Ca), alkaline (Alk) and tholeiitic (Th) fields denoted. C Plot of $\mathrm{Al}_{2} \mathrm{O}_{3} \mathrm{vs} \mathrm{SiO}_{2}$. D Trace element data normalised against normal mid-ocean ridge basalt (NMORB) showing

vesicularities $<5 \%$, indicating significant degassing prior to effusion (cf., Deniel et al. 2020). The OBP represents the final, volumetrically subordinate explosive phase of the EC eruption. Angular pumice clasts contain discrete microlite-rich regions which may represent incorporation of accumulated degassed melt from the conduit margins (cf., Mitchell et al. 2019). Evidence for persistence of conduit accumulations of densified melt is provided by obsidian bombs. A late-stage explosive magmatic eruption may be linked to shallow pressurisation from the closure of degassing pathways beneath the flow and dome or continued deep evolution of the final eruptible melt leading to increased overpressures or a combination of the two. proximal pumices depleted in $\mathrm{Ba}$ and $\mathrm{Sr}$ relative to the lavas and OBP. Trace element data is from LA-ICPMS analyses apart from $\mathrm{Zr}$, from whole rock XRF data, normalisation values from Hofmann (1988). E Trace elements normalised to chondrite showing proximal pumices are depleted in Eu relative to the lavas and OBP, normalisation values from

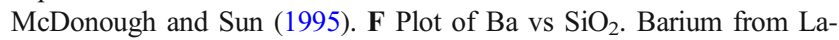
ICPMS and $\mathrm{SiO}_{2}$ from whole-rock XRF analysis. $\mathbf{G}$ Plot of $\mathrm{Zr}$ vs $\mathrm{SiO}_{2} . \mathbf{H}$ Plot of $\mathrm{MgO}$ vs $\mathrm{SiO}_{2}$. I Plot of $\mathrm{K}_{2} \mathrm{O}$ vs $\mathrm{SiO}_{2}$. C, F, G, $\mathbf{H}$ and $\mathbf{I}$ show proximal pumices are compositionally more similar to each other than to the lavas and OBP.

\section{Evolution and variability of vesicle textures}

For lapilli with little or no post-fragmentation textural alteration, crystallinity, bulk vesicularity and vesicle shape and size are all controlled by magma properties and ascent dynamics (Cashman and Mangan 1994). Viscosity, volatile content and ascent rate of the melt all influence vesicle and crystal nucleation and growth (Cashman and Mangan 1994). The textural fingerprint of a lapilli population is thus the outcome of spatial and temporal variations in these parameters. Hence, even qualitative comparison of these features can identify key step changes in ascent dynamics that lead to transitions in eruptive style. 
Table 2 Calculated viscosity for EC units and comparison magma compositions

\begin{tabular}{lllll}
\hline & Peralkalinity index (PI) & Temperature $\left({ }^{\circ} \mathrm{C}\right)^{*}$ & $\mathrm{H}_{2} \mathrm{O}(\mathrm{wt} \%)$ & $\begin{array}{l}\text { Viscosity } \\
(\mathrm{Pa} \mathrm{s}) * *\end{array}$ \\
\hline E.C. Unit 1 (PF) & $\mathbf{1 . 0 1}$ & 900 & $1-4$ & $10^{5.5}-10^{3.6}$ \\
Unit 9 (PDC) & $\mathbf{1 . 0 4}$ & 900 & $1-4$ & $10^{5.4}-10^{3.6}$ \\
E.C. Dome & 1 & 900 & $1-4$ & $10^{5.1}-10^{3.3}$ \\
E.C. Lava & $\mathbf{1 . 0 1}$ & 900 & $1-4$ & $10^{5.1}-10^{3.4}$ \\
Basalt $^{1}$ & 0.38 & 1000 & $1-4$ & $10^{2.5}-10^{1.8}$ \\
Unzen Dacite $^{2}$ & 0.57 & 800 & $1-4$ & $10^{6.9}-10^{4.8}$ \\
Rhyolite $^{3}$ & 0.78 & 800 & $1-4$ & $10^{7.7}-10^{5.3}$ \\
Peralkaline Rhyolite (Aluto) $^{4}$ & $\mathbf{1 . 6 3}$ & 750 & $1-4$ & $10^{4.9}-10^{2.5}$ \\
\hline
\end{tabular}

PF Pumice fall unit, $P D C$ pyroclastic density current deposits.

${ }^{1}$ Basalt composition from Le Maitre (1976)

${ }^{2}$ Unzen Dacite composition from Giordano et al. (2005)

${ }^{3}$ Rhyolite composition from Le Maitre (1976) oxide data in supplementary data

${ }^{4}$ From Clarke (2020)

*Temperatures quoted are approximate eruptive temperatures from Giordano et al. (2004)

**Viscosities calculated using Giordano et al. (2008) apart from peralkaline rhyolite; Clarke et al. (2020) used the model of Di Genova et al. (2013) for peralkaline rhyolites.
By considering how vesicle textures develop prior to fragmentation, the relative influence of bubble growth, coalescence and shear on the melt for each stage of an eruption can be discerned. This principle is used to interpret characteristic vesicle textures of type 1-5 lapilli clasts and their relative abundance throughout the eruption to understand changes in eruptive style. Figure 10 shows how polydisperse vesicle textures evolve under sheared and non-sheared conditions and the dominant processes acting at each stage, as recorded in type 1-5 lapilli clasts. Immature vesicle populations forming in the absence of shear are recorded by type 1 clasts: maturation of vesicle textures through continued growth promotes bubble interference and coalescence (Sparks 1978; Klug and Cashman 1996) - type 2 clasts. However, ascending melt is subject to transverse velocity gradients: drag at conduit margins reduces ascent velocity relative to the centre of the flow, creating zones of intense shear associated with rapidly changing velocity (Polacci et al. 2003; Shea et al. 2012; Cassidy et al. 2018). If an immature vesicle population is sheared, small elongate vesicles will result (type 3). If a mature population is sheared, coarse elongate vesicles result (e.g. type 4), and shear-induced coalescence hastens development of permeable networks. When a permeability threshold is reached, outgassing occurs: if gas flux is insufficient, bubble collapse ensues (Shea et al. 2012). Resultant textures are heterogeneous: clasts have irregular vesicles, thick glass walls and lower bulk vesicularities (type 5, Fig. 10) (Polacci et al. 2003; Shea et al. 2012). Shea et al. (2012) showed that shear-induced vesicle collapse can increase the density of the eruption column sufficiently to induce column collapse and PDC formation.
Whether a juvenile clast population has immature or mature vesicle textures depends on when fragmentation occurs relative to growth, coalescence and relaxation $\left(\tau_{\mathrm{r}}\right)$ timescales (Moitra et al. 2013). As such, when magma properties of the rising melt column vary laterally, interaction with the fragmentation surface/threshold produces texturally heterogeneous pumice populations (Polacci et al. 2003). In the EC pumices, fragmentation captures vesicle populations: (i) before extensive bubble growth (type 1 and 3 if sheared); (ii) after coalescence is initiated but within $\tau_{\mathrm{r}}$ (type 2); (iii) after shearing and some coalescence, but before outgassing and vesicle collapse (types 3 and 4); and (iv) after outgassing and vesicle collapse (type 5). Changing proportions of sheared and dense clasts may then be associated with development of low velocity shear zones and the extent to which outgassing could progress before fragmentation. Conduit modification and changes in fragmentation depth and magma flux may have influenced the proportion of melt and maturity of vesicle populations within shear zones and hence the density profile at the point of fragmentation (cf., Klug and Cashman 1996; Shea et al. 2012; Cassidy et al. 2018).

We interpret the influx of sheared clasts in Unit 3 (Fig. 8) to reflect a widening of marginal shear zones within the conduit. The lack of dense clasts indicates that outgassing and vesicle collapse were not extensive prior to fragmentation. In contrast, dense clasts make up $25 \%$ of Unit 4 , reflecting onset of bubble collapse and densification of the eruption column. Further densification of the column occurred during eruption of Unit 9 (middle cone) with an even higher proportion of dense and sheared clasts marking a tipping point, beyond which column 
Fig. 10 Diagram showing bubble nucleation, growth and coalescence processes in the absence and presence of shear to form the five textural types observed in the Echo Canyon (EC) lapilli population. Types 1 and 2 record multiple nucleation events and progressive vesicle growth without shear. Types 3 and 4 show how shear impacts vesicle shape and coalescence. Type 5 occurs after coalescence leading to outgassing through permeable networks and bubble collapse. Black arrows show movement of volatiles through permeable networks. Shaded rectangles show initiation of main processes during textural evolution. Greyed-out type 5 represents this process in the absence of shear-a lesser contributor to EC clast textures.

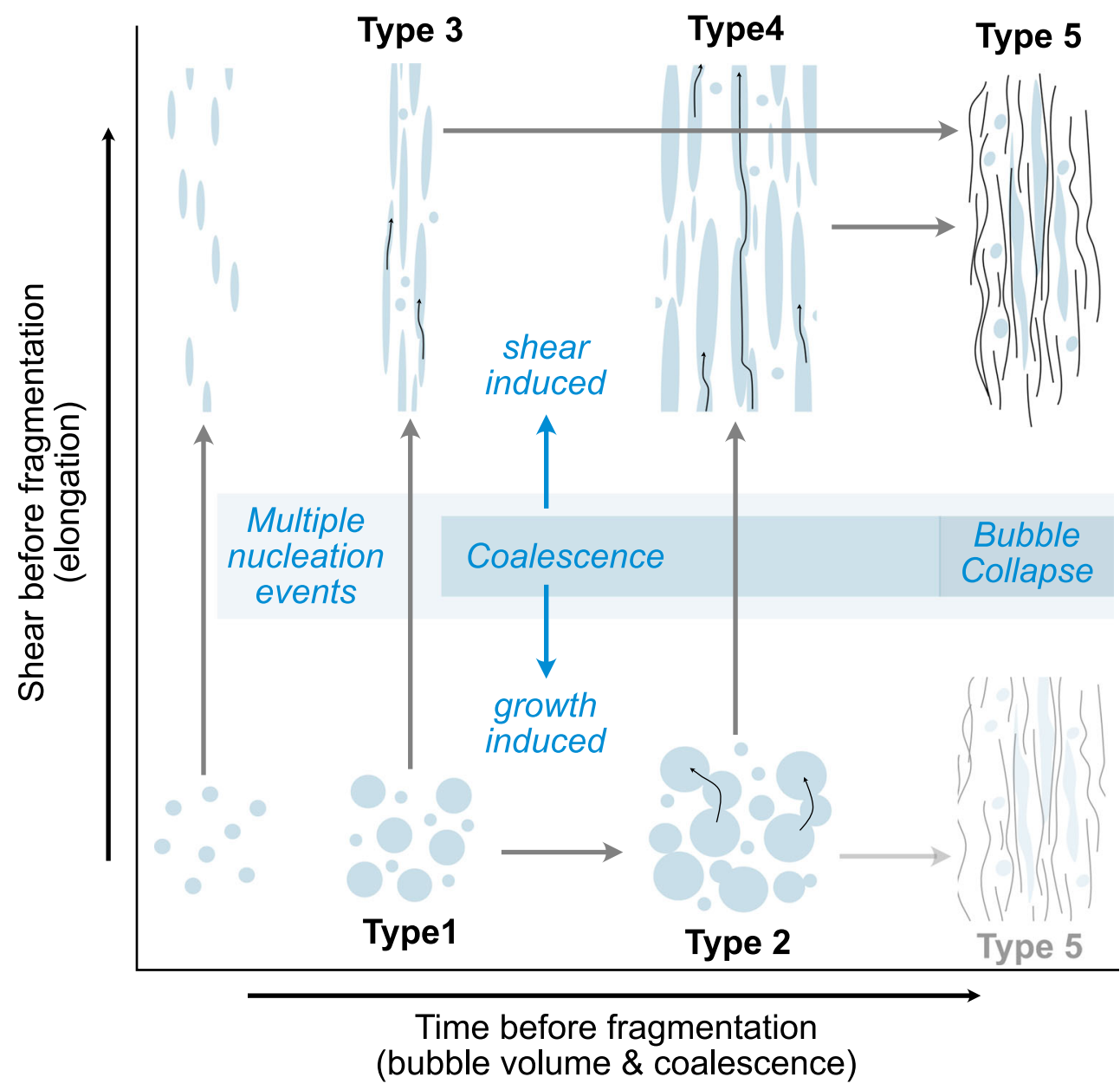

explosivity of small-volume basaltic eruptions on Hawaii, but this also requires accurate determination of eruption volumes. Standard scales of magnitude and intensity also fail to correctly capture the explosive potential, transient nature and associated hazards of individual phases of an eruption, or the timescales over which they may occur. Despite the coarseness of the VEI, its widespread use in volcanology and the media make it valuable when identifying and communicating potential hazards from future eruptions as they are often quoted in hazard assessments (Mastrolorenzo et al. 2017, Campi Flegrei and Sieron et al. 2019, Ceboruco volcano), and so careful comparisons - with caveats - can be worthwhile. In order to make interpretations of changing bulk processes in the ascending magma and link these to changing eruptive style for unobserved and poorly preserved eruptions, Mueller et al. (2011) compared clast bulk vesicularities of several eruptions with well-constrained eruption styles, dynamics and intensities. By doing so, they showed how such studies allow reconstruction of fragmentation mechanisms and eruption style. This is a useful approach, as the physical processes controlling a vesicle population also influence the explosivity and nature of fragmentation which are preserved in easily sampled juvenile clasts. By comparing vesicularity data of individual Houghton et al. (2013) extended the VEI to better capture 
phases from the EC eruption to eruption data collated by Mueller et al. (2011), we identify step-changes in fragmentation mechanism and explosivity that would otherwise be masked or inappropriately categorised using bulk properties of deposits. Mueller et al. (2011) preferentially sampled clasts from phases that represented the peak intensity for the VEI assigned to the eruption, e.g. only the Plinian fallout phases of the Novarupta 1912 eruption. This means that direct comparisons can be made between these eruptions and the EC units as both datasets represent specific eruption phases rather than an integral of bulk deposit vesicularity for the eruption as a whole.

Figure 11 is adapted from Mueller et al. (2011) and shows the BVDs (lines) and variance (bracketed numbers) of each EC pyroclastic unit alongside BVDs for several other eruptions. Shaded fields on Fig. 11 are the BVDs of several explosive eruptions of well-constrained eruption style and intensity. Explosive felsic eruptions represent sub-Plinian to ultraPlinian peak activity. Mafic eruptions represent HawaiianStrombolian activity.

Variance of BVDs can be used to infer fragmentation mechanism. Low variance BVDs reflect fragmentation by bubble interference and rupture (Sparks 1978). In contrast, high variance reflects transient fragmentation controlled by decompression processes where bubble overpressure exceeds the strength of the melt (Fowler et al. 2010).

For the EC eruption, variance decreases between Units 1 and 3, then increases by a factor of 3 in Unit 4 and peaks in Unit 9. Variance in the PDC deposits and overlying OBP are lower than that of Unit 9 but remain high. We suggest, therefore, that the dominant fragmentation mechanism shifted during the eruption. Fragmentation controlled by bubbleinterference became increasingly important as early activity progressed. From Unit 4 onwards, transient fragmentation controlled by decompression processes became increasingly dominant. This coincides with the onset of vesicle collapse, PDC formation and ultimately the explosive-effusive transition. Bulk vesicularity distributions of pumice fall Units $1-3$ progressively narrow, closely matching the daciticrhyodacitic, Plinian eruption of Krakatau in 1883. Units 4, 9 and 11 have broader distributions and lower modal bulk vesicularities than Units $1-3$, but neither their shape nor modal vesicularities match closely with those of the mafic explosive eruptions. Bulk vesicularity distributions are shifted to higher vesicularities in systems with polydisperse and deformed vesicles that have not yet undergone collapse (Mueller et al. 2011). The position of the porosity distribution thus relates to magmatic volatile content and degree of outgassing at the point of fragmentation (Mueller et al. 2011): BVDs of Units 1-3 suggest higher magmatic volatile content for early phases. Later stages, e.g. Units 4 and 9, were more outgassed, displaying lower bulk vesicularities and supporting our interpretation of clast densification through progressive development of connectivity and outgassing.

The trachytic Campanian Ignimbrite is classified as Plinian (Polacci et al. 2003), as is Krakatau 1883 (Mueller et al. 2011), showing that low viscosity trachytic melts are capable of highly explosive activity producing stable plumes. As the BVDs for Unit 3 and the Krakatau 1883 eruption are similar, we infer that Unit 3 may record a comparable transient peak intensity during the EC eruption. The low lithic content, thickness and massive, clast-supported nature of this unit support the interpretation of a stable plume. Units 1 and 2 have very similar BVDs to Unit 3 but contain more lithic clasts and are interbedded with ash beds, indicating the lack of a well-developed plume in contrast to Unit 3 . Unit 4 is unusual as it has very
Fig. 11 Comparison of Echo Canyon (EC) vesicularity distributions with eight eruptions of well-constrained eruption style and intensity. Non-EC bulk vesicularity curves (shaded regions) are adapted from Mueller et al. (2011) Fig. 2. Bulk vesicularity distributions of $\mathrm{EC}$ units are plotted as solid and dashed lines. Variance of clast vesicularity for each EC unit is displayed in brackets.

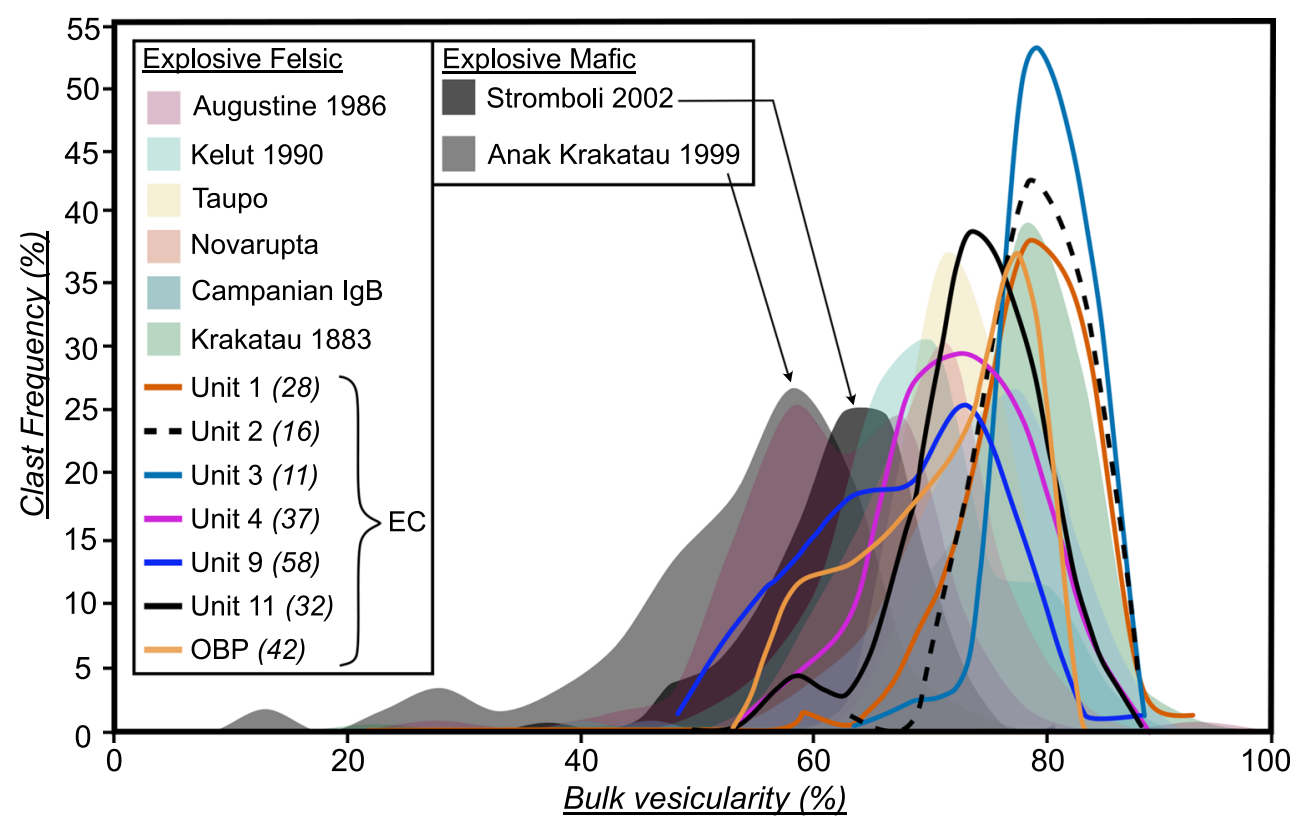


similar deposit characteristics to Unit 3, but the BVD (Fig. 11) and juvenile clast population for Unit 4 (Fig. 8) indicate significant changes to fragmentation mechanism, vesicle connectivity and outgassing. The mismatch between deposit characteristics, BVD and the lapilli population indicates some lag between the onset of densification processes and changing eruption style. The eruption does not shift to unsteady, subplinian activity until the middle and upper cone, Units 9 and 11. For Unit 9, the BVD (Fig. 11), lapilli population (Fig. 8) and lithologic characteristics (Figs. 3, 7D and 8 and Appendix 1) are all consistent with a transition to a destabilising plume and ultimately PDC formation producing Unit 11 .

Bulk vesicularity distributions, when combined with careful interpretation of deposit characteristics can provide insights into the bulk behaviour of ascending magmas, changing conduit dynamics and resulting eruptive style (Mueller et al. 2011). This is vital for reconstruction of unobserved eruptions. However, there are limitations to this approach. While important interpretations of volcanological processes and the associated hazards can be made, quantification of degassing, water exsolution and discharge rates and hence column heights require further analyses. Quantification of textures using vesicle and crystal size distributions (VSD and CSD) and microlite number densities allow modelling of these parameters (Toramaru 2006 and Toramaru et al. 2008). However, such textural analyses, particularly VSDs, require careful assessment of coalescence, bubble relaxation and elongation prior to analysis (e.g. Mitchell et al. 2019; Houghton et al. 2010; Shea et al. 2010). In addition, intensive parameters, e.g. initial and eruptive melt volatile concentrations and temperatures, must be first established to produce reliable model results (Toramaru 2006). While quantification of textures in this manner is beyond the scope of this paper, interrogation of the deposit characteristics, pervasive clast textures and BVDs provide a volcanological framework onto which quantitative modelling of eruption dynamics using micro-scale textures can later be applied.

The geometry, extent and proximal nature of the preserved EC fall and PDC deposits, lava and dome, suggest an eruptive volume of approximately $0.01-0.3 \mathrm{~km}^{3}$ comparable to Mayor Island and Aluto (Table 1). In isolation, the volume would yield an approximate VEI of 2 for this eruption, suggesting low intensity, fountaining eruptive styles. The deposit componentry, clast textures and BVDs, however, reveal a transient Plinian-style eruption peak followed by unsteady, sub-Plinian activity. While a VEI 6 classification is precluded by the small eruptive volumes, it is clear that explosion intensities and stable eruption columns, equivalent to those observed during VEI 6 eruptions, can be achieved, if only transiently, in the course of events like the Echo Canyon eruption. Rapid evolution of vesicle textures and outgassing combined with almost complete degassing of the melt promoted column collapse, later progressed to effusive activity, indicating the stable column could not be sustained for long. Similar complex eruption dynamics are preserved in other alkaline pumice cones, e.g. Pu'u Wa'awa'a, Hawaii (Shea et al. 2017), Aluto (Clarke 2020) and Mayor Island (Houghton et al. 1985; Houghton et al. 1992) indicating rapid transitions in eruptive style and intensity are common for eruptions of this composition and volume. The role of obsidian and tuffisite formation in accelerating these transitions is discussed in the following section.

\section{Obsidian breccia, tuffisite formation and degassing pathways}

Fragments of homogenous, banded and brecciated obsidian are first observed in PDC deposits, Unit 11, of the upper cone stratigraphy, coincidental with destabilisation of the plume and initiation of transition to effusive activity. Eruption of obsidian may evidence processes underpinning transitioning eruptive style. Obsidian pyroclasts can form via densification of melt during bubble collapse due to permeable outgassing (Shea et al. 2017) or through sintering and relaxation of ash particles (Gardner et al. 2017): both can occur at varying depths within the conduit. Crystallinity of the EC obsidian is varied, some clasts contain $<<1 \%$ microlites, while others have $>40 \%$. Cracks and small rounded-elongate vesicles in crystal-poor obsidian may suggest formation by sintering (Gardner et al. 2017). However, irregular vesicles aligned parallel to microlites visible in thin sections of crystal-rich obsidian, and vesicular banding seen in hand specimen, indicate formation by vesicle collapse (Shea et al. 2017). Similarities in macroscale textures between the EC clasts and the Shea et al. (2017) obsidian lead us to favour vesicle collapse as the dominant formation process and further evidence of extensive degassing prior to effusive activity.

Observations made during the eruptions of Chaitén (2008-2009) and Cordón Caulle in Chile (2011-2012) and subsequent work on tuffisites (Alfano et al. 2012; Castro et al. 2014; Pistolesi et al. 2015; Heap et al. 2019) have highlighted the complexity of degassing processes during eruptions of silica-rich melt. Brecciated obsidian tuffisites have been shown to record processes of magmatic autobrecciation and explosive degassing via the influx of hot gas, ash and rock mixtures at the conduit margins (Rust et al. 2004; Saubin et al. 2016; Heap et al. 2019). The occurrence of tuffisite fragments in the PDC deposits suggests accumulation of outgassed melt on the conduit walls and brittle development of permeable pathways prior to the explosive-effusive transition. Castro et al. (2014) showed that tuffisites extending 10 's-100's of metres into the conduit can act as a transient degassing system shifting activity from explosive to effusive. Strongly bimodal porosity/bulk vesicularity 
distributions are inferred to represent sampling of material with multiple degassing histories, for example, dome growth or plug formation (Mueller et al. 2011). Units 9 and 15 have BVDs that very weakly tend towards bimodality which indicates material with a different degassing history may have been sampled. This second degassing history does not, however, exert as strong a control on the shape of the BVD as one might expect for a period of dome/plug formation. Tuffisites, however, are a record of transient, explosive degassing within the volcanic system (Castro et al. 2014). A secondary degassing pathway which is transient may exert a weaker control on the BVD, resulting in the weakly bi-modal BVDs of Units 9 and 15 of the EC eruption. If tuffisites intersected with deeper magmatic foams, they may have also contributed to densification of ascending melt prior to effusive activity (Saubin et al. 2016). Obsidian and tuffisite formation, therefore, may have had an important role in facilitating rapid transitions from explosive to effusive activity during the EC eruption.

\section{Melt composition, viscosity and eruption dynamics}

There is now a wealth of evidence that trachytic eruptions can exhibit a similar range in eruptive style as larger calc-alkaline eruptions (Table 1). However, the question of how the physical properties of trachytic melts influence eruption dynamics, particularly in the case of small-volume events, remains. Bubble growth, coalescence, melt relaxation and collapse have a key influence on eruption dynamics and are all strongly controlled by the viscosity and volatile content of the melt (Cashman and Mangan 1994). At reasonable estimates of 14 wt \% water (e.g. those seen for other eruption on Ascension cf., Kar et al. 1998; Chamberlain et al. 2016, 2019, 2020)), the EC eruption products have an estimated viscosity of $10^{5.5}$ $10^{3.5}$ Pas, two orders of magnitude lower than a calcalkaline rhyolite with the same water content at a reasonable eruptive temperature (Table 2). For the EC trachytes, low viscosity and high $\mathrm{H}_{2} \mathrm{O}$ diffusivity mean high bubble overpressures are unlikely to be maintained (Shea et al. 2017). Under such conditions, brittle fragmentation and high intensity explosive activity is more difficult to achieve with reasonable ascent rates and conduit geometries (Hughes et al. 2017). Nevertheless, localisation of strain within the melt column changes melt rheology at multiple length and timescales during ascent and can facilitate brittle fragmentation in peralkaline melts (Hughes et al. 2017). Inter- and intra-clast textural heterogeneity suggests strain localisation was prevalent in the melt column during the EC eruption. Furthermore, Hughes et al. (2017) suggested that high initial magmatic $\mathrm{H}_{2} \mathrm{O}$ concentrations and low viscosity may promote rapid decompression within peralkaline melts. With an estimated 1-4 wt $\%$ initial $\mathrm{H}_{2} \mathrm{O}$ content in the $\mathrm{EC}$ melt, the tendency of trachytes to vesiculate rapidly during decompression (Shea et al. 2017) and evidence of strain localisation may explain the high intensity of early explosive phases. In addition, the water content at the point of fragmentation may be lower than the peak preeruptive value, increasing the viscosity and further easing fragmentation to some degree. Low viscosities also reduce timescales of melt re-organisation, allowing vesicle networks to respond rapidly to shear strain and outgassing, pushing eruptions towards effusive activity — which may explain why these high intensity explosive phases seem to be so shortlived. Although beyond the scope of this study, quantification of pre-eruptive and late-stage $\mathrm{H}_{2} \mathrm{O}$ concentrations would provide further constraints on the evolution of trachytic melt viscosity during the eruption and will be the focus of future work.

Degassing-induced crystallisation is another contributing factor in the transition from explosive to effusive activity, as increasing viscosity induces shear stress in the conduit promoting construction of spines and lobes (Deniel et al. 2020). In calc-alkaline dome-forming eruptions, groundmass crystallinities rarely exceed 50\% locally, and PDCs are regularly triggered by Vulcanian blasts due to gas overpressure in the dome (Deniel et al. 2020). In contrast, the trachytic Puy de Dôme in France is glass-poor, and only a few syn-dome explosions are recorded. The Puy de Dôme eruption closed with an explosive magmatic phase with a volume subordinate to the main edifice - similar to the final, OBP, phase of the EC eruption (Deniel et al. 2020). Deniel et al. (2020) argued that high crystallinities reflect efficient and near-complete degassing of the magma prior to and during dome construction. The intrinsic properties of trachyte melts and high dome permeability due to extensive fracturing facilitate this process (Deniel et al. 2020). For the effusive products of the EC eruption, high crystallinities may also record extensive degassing. As argued by Deniel et al. (2020), the physical properties of trachytic melts help to facilitate this process. In this instance, however, the additional high permeability may have been achieved via the presence of transient open fracture networks, evidence for which is the tuffisite fragments, transiently increasing conduit permeability at the explosive-effusive transition (e.g. Castro et al. 2014). The explosive post-dome eruption of the OBP mirrors that of the Puy de Dome eruption: so, significantly, dome formation does not preclude further explosive magmatic activity during short-lived, small-volume eruptions.

The physical behaviour of trachytic melts during ascent can produce high-intensity explosive phases and swift explosiveeffusive transitions. High-intensity phases are short-lived as bubble overpressures are not maintained, rapidly evolving vesicle textures promote outgassing and extensive degassing-induced crystallisation occurs. The "kinetic reactivity" (Shea et al. 2017) of trachytic melts explains the varied eruption dynamics of these small-volume eruptions, as recorded in their diverse juvenile clast populations. 


\section{Eruption sequence and dynamics summary}

Interpretations of stratigraphic observations, juvenile clast populations and textures and BVDs are integrated and evolution of EC eruption dynamics reconstructed and summarised below and in Fig. 12. Where possible, we draw comparisons between the EC eruption and other small-volume trachytic eruptions from Table 1 to show how the EC eruption enhances our understanding of these events worldwide.
Early Strombolian-Vulcanian fountaining is recorded by Units 1 and 2 (Fig. 12A-C), common for these smallvolume trachytic events, e.g. the non-welded pumice fall facies at Payún Matrú, Argentina (Hernando et al. 2019) (Table 1). A volumetrically subordinate cycle of accumulation and disruption of dense melt in the conduit then produced the VVLP clasts and ash beds of Unit 2 (Fig. 12B and C). Bulk vesicularity distributions (Fig. 11) and lapilli populations (Fig. 8) for Units 1-3 indicate during early phases, volatile-rich
Fig. 12 Boxes A-I represent key phases in the Echo Canyon eruption, as discerned from eruption stratigraphy and analyses of juvenile clasts. An idealised cone is presented with stratigraphic units as described in main text accumulating after each phase. Underlying topography and wind direction are not reflected here. Numbered inset boxes show schematics of processes of vesicle evolution as interpreted from juvenile clast texture, from 1 to 7 show increasing importance of marginal shear zones on bubble structure, connectivity and outgassing. Box 8 shows a detailed view of hybrid explosive effusive activity that formed Unit 12 at the projected vent region. Box 9 shows a possible mechanism for production of clasts with crystalline regions in the orange-brown pumice.

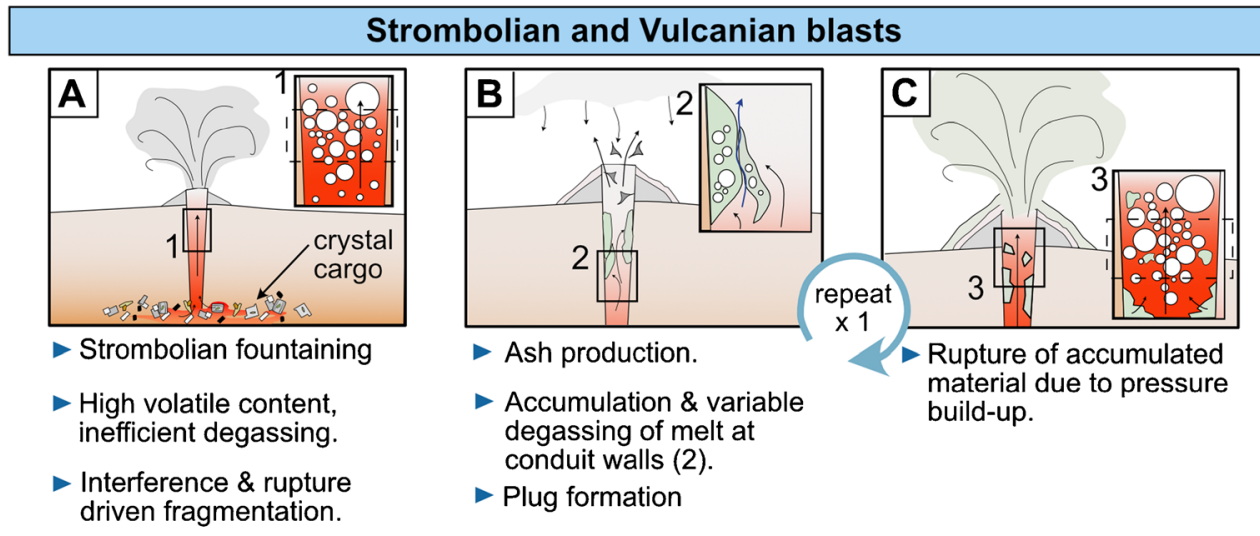

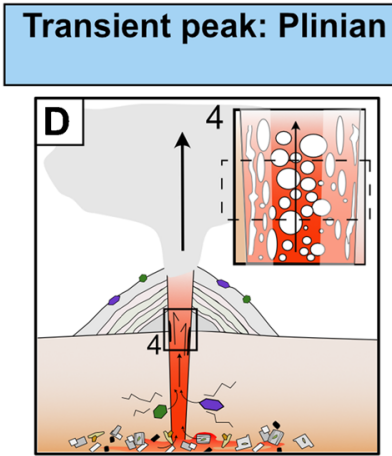

- Shear zones initiate at margins

- Conduit instability at depth, plutonic clasts erupted

- Permeable networks not yet developed = stable plume

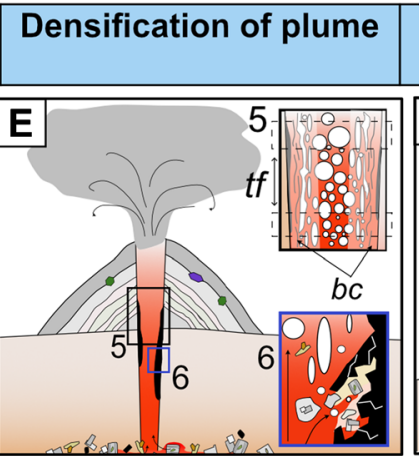

- Shear zones expand. permeable networks develop.

- Bubbles collapse \& melt accumulates.

- Transient fragmentation ( $t$ ) dominant.

- Tuffisite formation begins (6).
Sub-plinian unstable plume

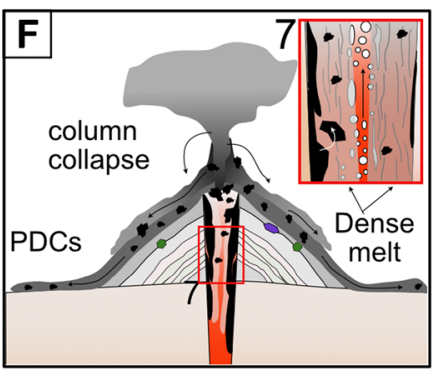

- Extensive outgassing $=$ melt accumulation \& fragmentation of obsidian at conduit margins.

- Tuffisites = secondary outgassing pathway

- Increased densification of melt and column.

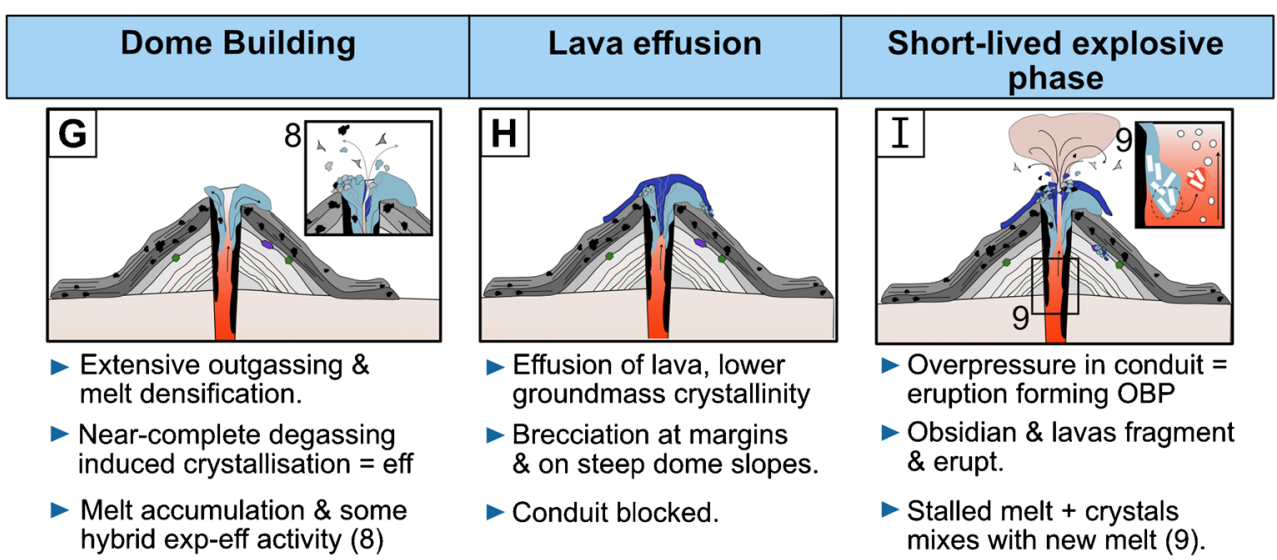


melt vesiculated rapidly during ascent and decompression, fragmenting by bubble interference and rupture (Fig. 12AD). Lithologic characteristics of Units 3 and 4 indicate the subsequent formation of a stable plume with a transient Plinian peak in activity, supported by the BVD of Unit 3 (Fig. 11). Initiation of marginal shear zones in the conduit introduced sheared clasts to the juvenile population in Unit 3. Unit 4 juvenile clasts record propagation of marginal shear zones and enhanced connectivity of vesicle networks and initiation of melt densification and accumulation: the BVD of Unit 4 shows transient fragmentation became more dominant (Fig. 12D and E5). The contradiction between the juvenile clast population and the BVD (Figs. 8 and 11) of Unit 4, and its lithologic characteristics, indicates a lag between the initiation of melt densification and destabilisation of the plume. Heterogeneous clast textures and obsidian formation are common in trachytic eruptions (Houghton et al. (1985); Shea et al. 2017) suggesting trachytic melts support multiple complex degassing histories in the conduit even for small eruptive volumes (Shea et al. 2017). Tuffisite formation on the conduit walls provided an additional outgassing pathway (Fig. 12E6) as continued melt densification initiated partial column collapse and PDC formation (Fig. 12E). Subsequent conduit destabilisation sampled accumulated obsidian and tuffisites during deposition of Unit 11 (Fig. 12E and F). In late stages, near-complete degassing resulted in high crystallinities and aided a transition to effusive activity forming the dome and brecciated lava, with hybrid activity likely at the initial transition (Fig. 12G and H). Pressurisation beneath the dome produced a final magmatic explosive eruption, the OBP, incorporating accumulations of degassed melt from the conduit walls producing heterogeneously microcrystalline clasts (Fig. 12I). The excellent exposure of the EC eruption deposits provides a near-complete record of the eruption and shows that many of the processes identified across the eruptions in Table 1 can occur within a single eruption period and may even be the norm for events of this type.

\section{Conclusions}

We use unusually well-preserved and exposed deposits on Ascension Island, South Atlantic, to reconstruct a smallvolume explosive-effusive trachytic eruption. By combining the detailed eruption stratigraphy with analysis of individual and bulk clast densities, we demonstrate that eruptions of this type are capable of short-lived periods of high intensity explosions and rapid transitions in eruptive style. In particular we show that:

(1) The Echo Canyon eruption had multiple transitions in eruptive style controlled by bulk regimes which transitioned from that controlled by rapidly vesiculating magma to one controlled by the development of shear zones and networks that allowed transient fragmentation to dominate, initiating column collapse.

(2) Magmas of trachytic composition are capable of producing Plinian explosive phases equivalent to those seen at the peak of VEI 6 eruptions, but our evidence and the global record suggest that these are unlikely to be sustained for long periods, as a consequence of relatively more efficient outgassing. Ultimately, this and degassing controlled crystallisation in these 'kinetically reactive' magmas encourages the development of effusive activity.

(3) Our detailed analysis reveals that these abrupt transitions could be characteristic of these low-volume silicic magmas which are found worldwide. The varied eruption styles and swift transitions exhibited by small-volume trachytic eruptions have significant implications for our understanding of volcanic hazard, particularly in remote ocean island settings.

(4) Combined analysis of BVDs, macro-scale clast textures and deposit characteristics allows reconstruction of the bulk characteristics of ascending melts revealing changes to conduit and eruption dynamics. Quantification of micro-scale vesicle and crystal textures and changing volatile content and viscosity would enable modelling of useful parameters such as degassing and discharge rates and will be the focus of future work.

Textural studies of other preserved deposits are vital to identify patterns in eruption style, and further investigation of fragmentation in trachytes is required to understand how high-intensity eruptive periods initiate. Recognising signals of these processes in monitoring data will be critical for ongoing hazard assessment in regions that produce small-volume trachytic eruptions.

\section{Appendix 1 Stratigraphic descriptions}

\section{Cone deposits}

Units $1-10$ of the lower and middle cone and unit 12 of the upper cone were logged in detail at localities AI18-04, AI1822 and AI1 8-23 in Echo Canyon. Unit 11 was observed from a distance at locality AI18-22 and logged in detail at locality AI19-02 and 52 in Rainbow Canyon. Localities and deposits are shown on Fig. 13, sample numbers and locations are given in Table 3. Juvenile clast types other than lapilli types 1-5 are described in Fig. 14. 
Fig. 13 Geological map of the EC deposits in NE-Bay with key localities as referenced in the main text marked as red stars.

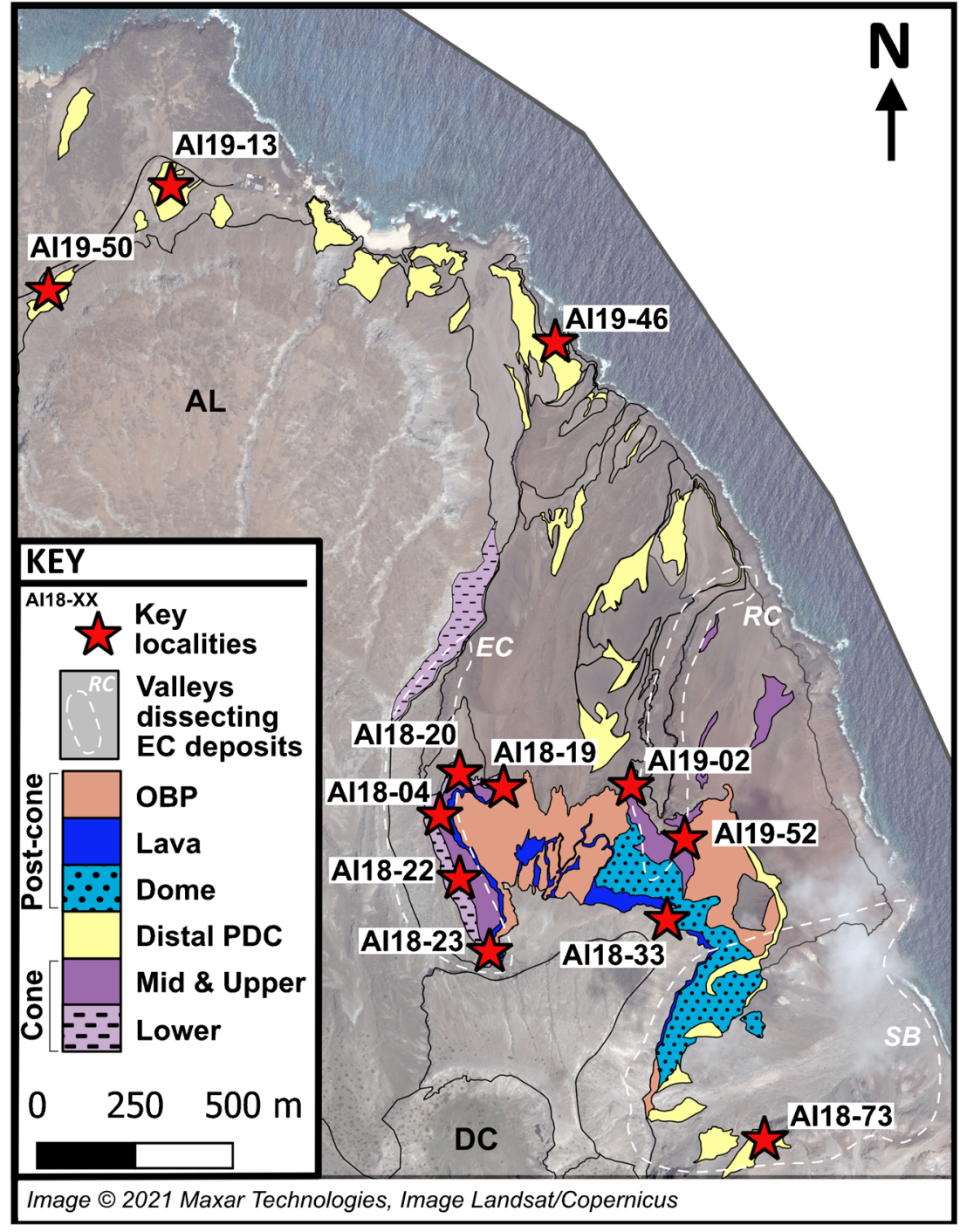

Table 3 Sample locations with locality numbers and sample descriptions

\begin{tabular}{llll}
\hline Sample number & Locality & Grid reference (UTM, zone 28S) & Description \\
\hline AI18-842A & AI18-04 & $-7.930696,-14.328462$ & Unit 1 pumice \\
AI18-843A & AI18-04 & $-7.930696,-14.328462$ & Unit 2 pumice bed \\
AI18-843C & AI18-04 & $-7.930696,-14.328462$ & Unit 2 vesicular end member of VVLP clasts \\
AI15-602B & 2015 Echo Canyon & $-7.930677,-14.328498$ & Unit 2 dense endmember VVLP clasts \\
AI18-844A & AI18-04 & $-7.930696,-14.328462$ & Unit 3 pumice \\
AI18-844C & AI18-04 & $-7.930696,-14.328462$ & Unit 4 pumice \\
AI18-844E & AI18-04 & $-7.930696,-14.328462$ & Unit 4 lapilli tuff block example \\
AI18-829A & AI18-22 & $-7.931708,-14.328216$ & Unit 9 pumice \\
AI18-845B & AI18-04 & $-7.930696,-14.328462$ & Unit 9 equivalent, breadcrust bombs \\
AI18-845C & AI18-04 & $-7.930696,-14.328462$ & Unit 9 equivalent, angular banded bombs \\
AI19-006 & AI19-02 & $-7.930211,-14.323915$ & Unit 11 obsidian breccia \\
AI19-137 & AI19-52 & $-7.930808,-14.322408$ & Unit 11 pumice rich layer \\
AI18-871B & AI18-33 & $-7.933265,-14.323332$ & Post cone dome lava \\
AI18-828C & AI18-20 & $-7.930233,-14.327792$ & Post-cone brecciated lava \\
AI18-827C & AI19-19 & $-7.93025,-14.326757$ & Post-cone orange-brown pumice (OBP) \\
\hline
\end{tabular}


Fig. 14 Descriptions of clasts commonly found in the Echo Canyon deposits. ${ }^{1}$ VVLP, Variably Vesicular Lava-Pumice clasts; ${ }^{2}$ Dense end-member average determined from 3 typical clasts; ${ }^{3}$ vesicular endmember average from 4 typical clasts; ${ }^{4}$ see Appendix 2, Fig. 22 for petrography of EC

phenocrysts; ${ }^{5}$ Obsidian breccia determined from 3 typical clasts; ${ }^{6}$ average lapilli tuff bulk vesicularity taken from one measurable representative clast. A Breadcrust bomb exterior view. B Dense end-member equivalent of VVLP clasts Red pen is $14 \mathrm{~cm}$. C Side view of obsidian breccia clast showing relationship between obsidian and other brecciated material. Black bars are $1 \mathrm{~cm}$ for scale.

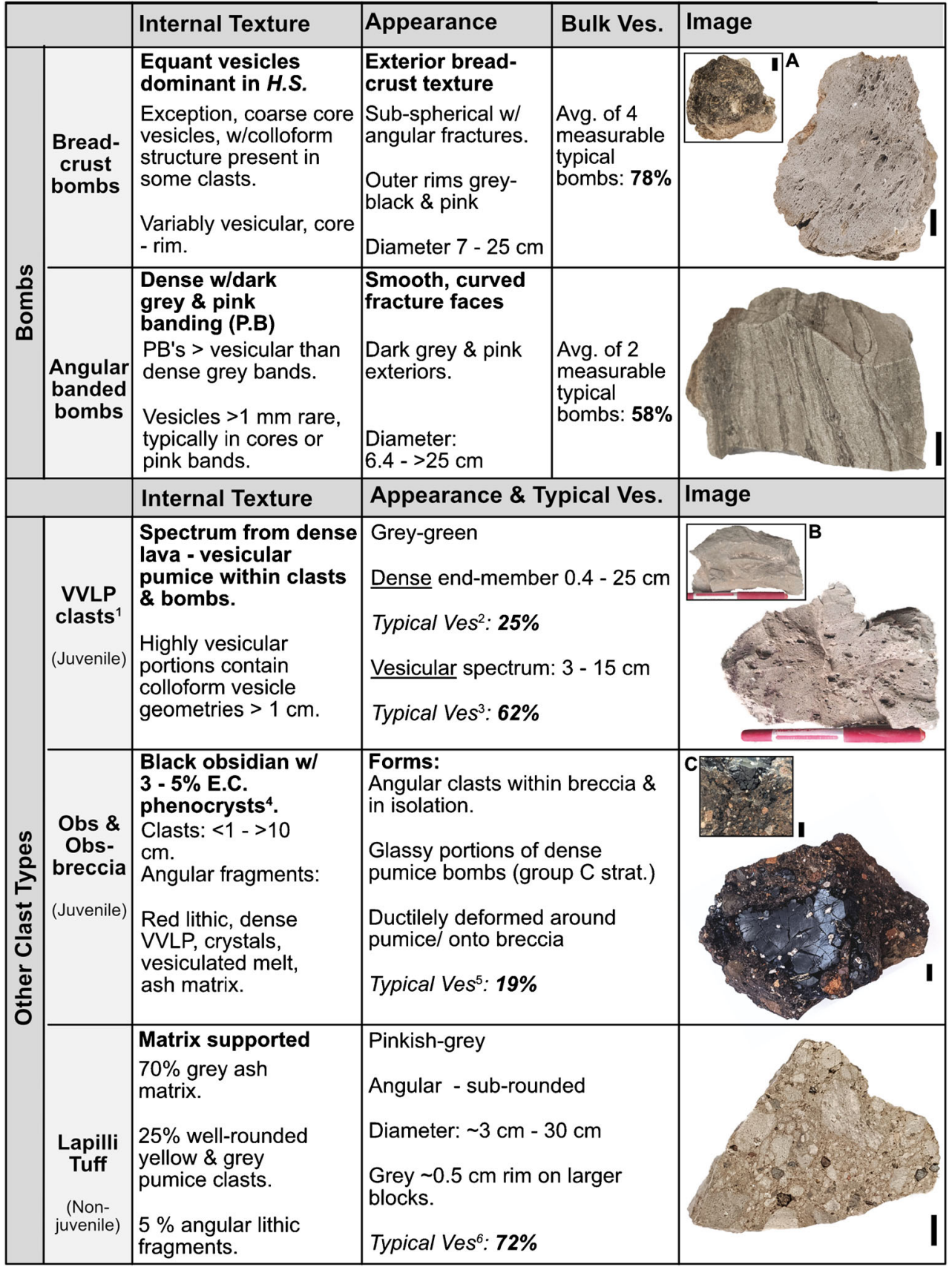

\section{Lower cone}

\section{Unit 1}

This unit is a 4-m-thick, massive, clast-supported pumice fall dipping $\sim 20^{\circ}$ north (Fig. 15A). Juvenile clasts comprise $85 \%$ of the unit, $<10 \%$ of which are bombs, and $\sim 5 \%$ are dense endmember VVLP clasts: lithic clasts make up $15 \%$ of the unit. Pumice lapilli are angular with a modal clast size of $2-3 \mathrm{~cm}$ and contain $\leq 1 \%$ feldspar and clinopyroxene crystals of 2-5 mm (Fig. 15B). Abundances of the five types of vesicle texture within pumice lapilli are macro-vesicular equant, 58\%; micro-vesicular equant,
26\%; macro-vesicular elongate, $4 \%$ and dense, $12 \%$. Bombs are 50:50 breadcrust and angular fragmented types; maximum diameter is $10 \mathrm{~cm}$. Lithic clasts are angular; common types in decreasing abundance are grey-black aphyric lava, red scoria and purpleblack aphyric vesicular lava. Modal lithic clast size is $3-4 \mathrm{~cm}$, and maximum clast size is $20 \mathrm{~cm}$. Clasts of lapilli tuff are rare, angular and less than $3 \mathrm{~cm}$. The upper contact with the basal ash bed of unit 2 is sharp, planar and continuous. The base of unit 1 is not exposed here but approximately $10 \mathrm{~m}$ below the outcrop downcanyon to the north, underlying lavas crop out. Unit 1 is laterally continuous with consistent dip; the outcrop extends approximately $100 \mathrm{~m}$ SSW up-canyon until obscured by alluvial canyon debris. 
Fig. 15 Outcrop photos of the lower cone taken at AI18-04. A Units $1-4$ of the lower cone, dominated by massive pumice fall deposits with three minor ash beds within Unit 2. Subtle colour change from light to dark grey marks the boundary between Units 3 and 4. B Angular clastsupported pumice fall of Unit 1. C Ash-rich bed and clast-supported pumice beds of Unit 2. D Pumice bomb within clast-supported pumice fall of Unit 3. E Clastsupported pumice fall of Unit 4 with angular pumice lapilli and $10 \%$ lithic clasts. F Example of an angular fragmented type bomb within Unit 4.
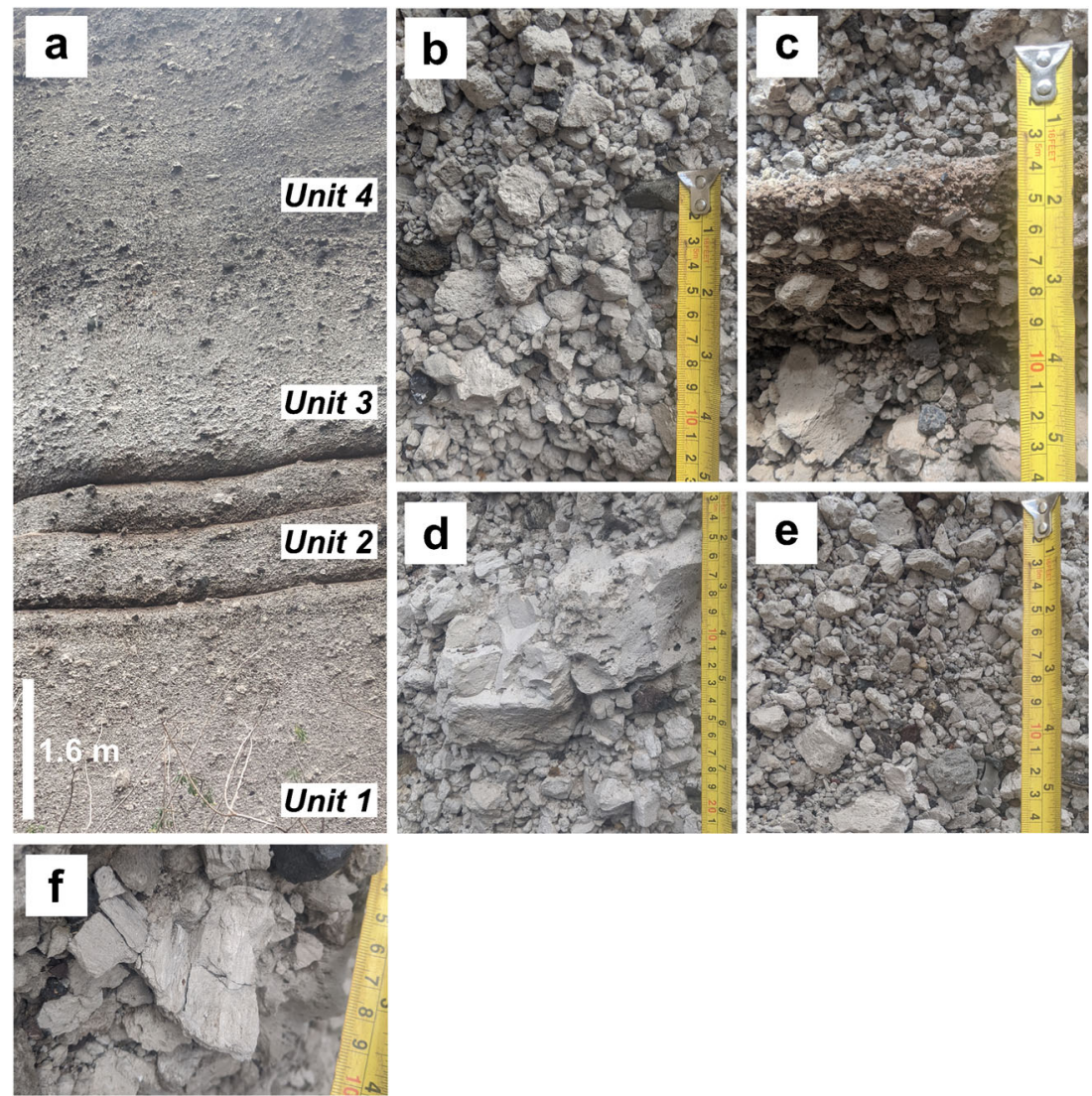

\section{Unit 2}

Unit 2 is $1.6 \mathrm{~m}$ thick and comprises three $\sim 10$-cm-thick ash beds interbedded with two clast-supported, massive pumice beds. The lower and upper pumice beds are $90 \mathrm{~cm}$ and $40 \mathrm{~cm}$ thick, respectively. Unit 2 lies conformably on Unit 1, dipping approximately $20^{\circ}$ north (Fig. $15 \mathrm{~A}$ ).

Ash beds are indurated and contain $80 \%$ ashy matrix, $10 \%$ pumice and 8-10\% lithic clasts (Fig. 15C). Pumice lapilli clasts are sub-angular, range from $<0.1$ to $4 \mathrm{~cm}$ and contain the same macrocryst population as those in Unit 1. Pumice bombs are rare, dominantly breadcrust type and have a maximum diameter of $25 \mathrm{~cm}$. Lithic clasts are angular and the same population as described for Unit 1. Modal and maximum lithic clast sizes are $<1 \mathrm{~cm}$ and $4 \mathrm{~cm}$, respectively. Ash beds are laterally continuous, mantle the irregular surface of underlying pumice clasts, have consistent thickness and dip and lack stratification.

Pumice beds comprise $80 \%$ pumice clasts, of which $<10 \%$ are bombs, 5-10\% VVLP clasts and $\sim 10 \%$ lithic clasts (Fig. 15C). Pumice lapilli are angular, have modal diameter of 3$4 \mathrm{~cm}$ and contain the same macrocryst population as those in Unit 1. Abundances of the five types of vesicle texture within pumice lapilli are macro-vesicular equant, 62\%; microvesicular equant, 28\%; macro-vesicular elongate, 4\%; microvesicular elongate, $2 \%$ and dense, $4 \%$. Pumice bombs are dominated by breadcrust type, but angular fragmented types are present, and maximum bomb diameter is $25 \mathrm{~cm}$. VVLP clasts occur across the spectrum from vesicular to dense, clast diameters range from $\sim 2$ to $30 \mathrm{~cm}$ and larger clasts tend to be more vesicular. Lithic clasts are angular and the same population as described for Unit 1. Modal and maximum lithic clast diameters are $2-3 \mathrm{~cm}$ and $10 \mathrm{~cm}$, respectively.

Contacts between ash and pumice beds within Unit 2 are sharp, planar and continuous, as are the lower and upper contacts of the Unit 2 ash beds with the pumice beds of Unit 1 and Unit 3. Unit 2 is laterally continuous with consistent dip; the outcrop extends approximately $120 \mathrm{~m} \mathrm{SSW}$, up-canyon until obscured by alluvial canyon debris.

\section{Unit 3}

Unit 3 is a 2-m-thick massive, clast-supported pumice fall that lies conformably on Unit 2, dipping approximately $20^{\circ}$ north (Fig. 15A). Juvenile clasts comprise $95 \%$ of the unit, $<5 \%$ of which are bombs and $<5 \%$ are VVLP clasts: lithic clasts make up $5 \%$ of the unit. Pumice lapilli are angular with a modal clast size of $4 \mathrm{~cm}$ and contain the same macrocryst population as Units 1 and 2 (Fig. 15D). Abundances of the five types of vesicle texture within pumice lapilli are macrovesicular equant, 37\%; micro-vesicular equant, 31\%; macrovesicular elongate, 15; micro-vesicular elongate, 16\%; and 
dense, $1 \%$. Bombs are dominantly breadcrust type and have a maximum diameter of $50 \mathrm{~cm}$, and larger bombs tend to be angular-fragmented type. VVLP clasts tend to be the dense endmember and have a modal diameter of $0.5 \mathrm{~cm}$. Lithic clasts are angular and comprise the same population as Units 1 and 2. Modal lithic clast size is $3-4 \mathrm{~cm}$; maximum diameter is 30 $\mathrm{cm}$. The upper contact with Unit 4 is also sharp and planar, marked by a change in unit colour-from pale grey to dark grey associated with a change in juvenile clast texture - and a concentrated layer of $10-30-\mathrm{cm}$ lithic clasts including granite and syenite. The lower contact with Unit 2 is sharp and planar, outcropping continuously for approximately $200 \mathrm{~m}$ to the SSW, where it becomes intermittently obscured by alluvial canyon debris.

\section{Unit 4}

Unit 4 is a 4-m-thick massive, clast-supported pumice fall that lies conformably on Unit 3, dipping approximately $20^{\circ}$ north (Fig. 15A). Juvenile clasts comprise $\sim 90 \%$ of the unit, $<5 \%$ of which are bombs: lithic clasts make up $10 \%$ of the unit, of which $<5 \%$ are lapilli tuff. Pumice lapilli are angular with a modal clast size of $4 \mathrm{~cm}$ and contain the same macrocryst population as the underlying units (Fig. 15E). Abundances of the five types of vesicle texture within pumice lapilli are macro-vesicular equant, 44\%; micro-vesicular equant, $17 \%$; macro-vesicular elongate, 4\%; micro-vesicular elongate, $10 \%$ and dense, $25 \%$. Bombs are dominantly the angularfragmented type (Fig. 15F) and have a maximum diameter of $50 \mathrm{~cm}$. Lithic clasts are angular and comprise the same population as the units below with the addition of clasts and blocks of lapilli tuff. Modal lithic clast size is 3-4 cm, maximum diameter is $30 \mathrm{~cm}$ for lava and scoria clasts and $50 \mathrm{~cm}$ for lapilli tuff. The contact between Units 4 and 5 marks the start of the middle cone. The boundary is marked by a gradational decrease in modal clast size from 4 to $2 \mathrm{~cm}$; this gradation spans $\sim 40 \mathrm{~cm}$. The boundary between units 3 and 4 is sharp and planar, marked by the darker grey colour of unit 4 and the concentrated layer of $10-30 \mathrm{~cm}$ lithic clasts, the only place where plutonic clasts were found within the cone stratigraphy. Unit 4 is laterally continuous with consistent dip; the outcrop extends approximately $200 \mathrm{~m}$ SSW, up-canyon until intermittently obscured by alluvial canyon debris.

\section{Middle cone}

\section{Unit 5}

Unit 5 is a $50-\mathrm{cm}$ thick, clast-supported pumice fall that lies conformably on Unit 4, dipping approximately $20^{\circ}$ north (Fig. 16A). Proportions of juvenile and lithic clasts change vertically throughout the unit. Juvenile clasts comprise $\sim 80-70 \%$ of the unit from base to top, $10 \%$ are dense endmember VVLP clasts and $<5 \%$ are bombs. Lithic clasts make up $20-30 \%$ of the unit from base to top. Pumice lapilli are angular, modal diameter grades from 2 to $0.5 \mathrm{~cm}$ vertically and contain the same macrocryst population as the underlying units. Abundances of the five pumice lapilli types were not quantified for this unit, but pumice lapilli tend towards denser vesicle textures: macro-vesicular textures are only observed in clasts $>4 \mathrm{~cm}$. Bombs are dominated by the angular-fragmented type, have a maximum diameter of $25 \mathrm{~cm}$ and occur throughout, regardless of grading. Dense endmember VVLP clasts are angular and modal clast size grades from 1.5 to $0.5 \mathrm{~cm}$ vertically. Lithic clasts are angular; common types in decreasing abundance and size are purple-black aphyric vesicular lava, grey-black lava with 1-2-mm feldspar phenocrysts and red scoria. Modal lithic clast size grades from 1.5 to $0.5 \mathrm{~cm}$ vertically, maximum lithic clast diameter is 4 $\mathrm{cm}$. Unit 5 is normally graded with finest particles of $<0.2 \mathrm{~cm}$ at the top of the unit. The upper contact with Unit 6 is sharp, planar and continuous, disrupted only by larger bombs protruding from Unit 5 into the base of Unit 6. The lower contact with Unit 4 is gradational as described above. Unit 6 is continuous with consistent dip for approximately $300 \mathrm{~m}$ up-canyon to the SSW, where it is obscured by alluvial canyon debris.

\section{Unit 6}

Unit 6 is a 10-cm-thick partially welded pumice and ash bed that lies conformably on Unit 5 dipping approximately $20^{\circ}$ north (Fig. 16B upper white bed, Fig. 16B white bed at base). The unit is dominantly matrix supported with cm-scale clast-supported lenses. Juvenile pumice comprises $95 \%$ of the unit, lithic clasts the remaining $5 \%$. Pumice lapilli are angular and have a modal diameter of $0.5 \mathrm{~cm}$; in larger clasts, the same macrocryst population as the other EC units is visible. Abundances of the five pumice lapilli types were not quantified for this unit, but pumice lapilli tend to be dense with dark banding. Both breadcrust and angularfragmented type bombs are present with a maximum diameter of $28 \mathrm{~cm}$. Lithic clasts of the purple-black aphyric vesicular lava and grey-black lava with 1-2mm feldspar phenocrysts are angular with a modal and maximum diameter of 0.5 and $12 \mathrm{~cm}$, respectively. The upper contact is sharp and continuous disrupted only by larger bombs protruding from Unit 6 into the base of Unit 7, as is the lower contact with Unit 5. Unit 6 is continuous with consistent dip for approximately $300 \mathrm{~m}$ up-canyon to the SSW, where it is obscured by alluvial canyon debris. 


\section{Unit 7}

Unit 7 is a 90-cm-thick sequence of clast-supported beds that lies conformably on Unit 6 dipping approximately $20^{\circ}$ north. Proportions of pumice and lithic clasts and modal clast sizes vary vertically through the unit (Fig. 16B). Juvenile clast abundance decreases from 90 to $50 \%$ over the first $70 \mathrm{~cm}$ of the unit, increasing to $95 \%$ in the upper $20 \mathrm{~cm} ;<5 \%$ of juvenile clasts are dense VVLP clasts. Lithic clasts make up the remainder of the unit. Pumice lapilli change from angular to subangular over the first $70 \mathrm{~cm}$, returning to angular in the upper $20 \mathrm{~cm}$ of the unit. Juvenile material contains the same macrocryst population as the other EC units. Abundances of the five pumice lapilli types were not quantified for this unit, but pumice lapilli are typically micro-vesicular with dark millimetre-scale banding. Modal juvenile clast diameter increases from 1.5 to $2 \mathrm{~cm}$ over the first $50 \mathrm{~cm}$ of the unit, maximum diameter increases from 5 to $20 \mathrm{~cm}$ over the same range. Above this is a 20-cm-thick section with modal and maximum juvenile clast sizes of $0.3 \mathrm{~cm}$ and $1 \mathrm{~cm}$, respectively; clasts here are the most rounded and may have been re-worked. The uppermost $20 \mathrm{~cm}$ of the unit has modal and maximum clast sizes of 1.5 and $20 \mathrm{~cm}$, respectively (Fig. 16C). Bombs are consistently $<10 \%$ of the pumice population and show both breadcrust and angular-fragmented types, with a visible continuum between the two; maximum bomb diameter is $20 \mathrm{~cm}$. Three different lithic clast types were observed; in decreasing abundance, these are purple-red vesicular aphyric lava, red scoria and grey-black aphyric lava. The lithic clast population is consistent throughout the unit and contains the same clast types observed in the other EC units; modal and maximum clast sizes are < $3 \mathrm{~cm}$ and $28 \mathrm{~cm}$, respectively. Throughout the unit, lithic clasts are angular and have modal and maximum clast diameters of $<3 \mathrm{~cm}$ and $28 \mathrm{~cm}$, respectively. Within the lower $50 \mathrm{~cm}$, variations in clast size and proportions do not occur with consistent thickness, pinching and swelling laterally. Clast sizes and proportions observed in the upper $40 \mathrm{~cm}$, however, are laterally continuous. The upper contact with Unit 8 is sharp and planar disrupted only by large pumice bombs and lithic clasts, as is the lower contact with Unit 6 . Unit 7 is continuous with consistent dip for approximately 300 $\mathrm{m}$ up-canyon to the SSW, where it is obscured by alluvial canyon debris.

\section{Unit 8}

Unit 8 is $18 \mathrm{~cm}$ thick and matrix supported; it lies conformably on Unit 7 dipping $\sim 20^{\circ}$ north (Fig. 16D).
Ashy matrix accounts for $70 \%$ of the unit and clasts 30\%-split 50:50 juvenile and lithic clasts. Juvenile clasts are sub-rounded to sub-angular and occur in discontinuous centimetre-scale lenses. Pumice lapilli have a modal clast size of $2 \mathrm{~cm}$ and contain the same macrocryst population as observed in other EC units. Abundances of the five pumice lapilli types were not quantified for this unit, but pumice lapilli are often dense and contain glassy obsidian bands and patches. Pumice bombs comprise $<2 \%$ of juvenile material and have a maximum diameter of $25 \mathrm{~cm}$. The lithic population is angular and contains black-grey lava with 1-2mm feldspar phenocrysts, red scoria and purple-black aphyric lava. Lithic clasts have modal and maximum clast diameters of $0.3 \mathrm{~cm}$ and $5 \mathrm{~cm}$, respectively, larger clasts are concentrated in lenses alongside pumice lapilli. Unit 8 marks the upper portion of the logged section at locality AI18-04, but the stratigraphy continues an additional $\sim 15 \mathrm{~m}$, and units are correlated across to locality AI18-22. The contact with the overlying units is sharp, planar and laterally continuous, disrupted only by larger bombs at the boundary with the overlying unit as is the lower contact with Unit 7.

\section{Unit 9}

Unit 9 is $40 \mathrm{~cm}$ thick and clast supported; it lies conformably on unit 8 dipping $\sim 20^{\circ}$ north. Juvenile clasts comprise $90 \%$ of the unit, inclusive $<10 \%$ bombs and dense endmember VVLP clasts: lithic clasts comprise $10 \%$ of the unit (Fig. 16E). Pumice lapilli are angular, and modal diameter increases from $5 \mathrm{~mm}$ in the basal $4 \mathrm{~cm}$ to $6 \mathrm{~mm}$ in the upper $6 \mathrm{~cm}$ of the unit. Abundances of the five types of vesicle texture within pumice lapilli are macro-vesicular equant, 17\%; microvesicular equant, 29\%; macro-vesicular elongate, 11\%; micro-vesicular elongate, $7 \%$ and dense, 36\%. Bombs are dominantly the angular-banded type, with a maximum diameter of $33 \mathrm{~cm}$, bombs coarsen upwards in the unit. Vesicles up to $2 \mathrm{~cm}$ diameter occur in the largest bombs. Obsidian chips are rare and $<3 \mathrm{~mm}$ in diameter. All juvenile material contains the EC macrocryst population as observed in the units below. Lithic clasts are angular; the population comprises a phenocryst bearing purple-red lava and grey phenocryst bearing lava. Modal lithic clast diameter increases from 0.2 to $3.5 \mathrm{~cm}$ up through the unit. The upper contact with unit 10 is sharp, planar and continuous, disrupted only by large pumice bombs protruding from the upper part of unit 9. The lower contact with unit 8 is the same. Unit 9 is continuous from AI18-04 to AI1822-where it was logged: unit 9 extends SSW for another $70 \mathrm{~m}$ until covered by alluvial canyon debris. 


\section{Unit 10}

Unit 10 was described from locality AI18-22 but was difficult to access in the steep cliff face (Fig. 16F), and so observations were brief, and no samples were collected. This unit marks the uppermost part of the middle cone; the overlying stratigraphy continues for another $20 \mathrm{~m}$ to the base of the brecciated lava and is best described at locality AI19-02 in Rainbow Canyon-see Unit 11 description.

Unit 10 is $90 \mathrm{~cm}$ thick, comprising interbedded matrix and clast-supported beds that lie conformably on unit 9 , dipping $\sim 20^{\circ}$ north. Matrix supported beds consist of $>95 \%$ ash and $<5 \% 2 \mathrm{~mm}$ pumice and lithic clasts. Matrix-supported beds are indurated and the outer surface stained reddish-brown. Clast-supported beds comprise $90 \%$ juvenile material including < $3 \%$ bombs: lithic clasts constitute $10 \%$ of the unit. Pumice lapilli are generally angular or sub-angular to sub-rounded with a modal diameter of $1 \mathrm{~cm}$, but some clastsupported beds contain clasts up to $4 \mathrm{~cm}$ diameter. Abundances of the five pumice lapilli types were not quantified for this unit, but pumice lapilli tend towards denser vesicle textures. Angular banded and breadcrust bomb types are present: maximum bomb diameter is 33 $\mathrm{cm}$. Lithic clasts are angular, comprising a phenocryst bearing purple-red lava and grey phenocryst bearing lava. Modal lithic clast diameter is $0.5 \mathrm{~cm}$, but clasts up to $4 \mathrm{~cm}$ diameter occur in beds containing the $4-\mathrm{cm}$ pumice clasts. The upper contact with a thick clastsupported unit is slightly undulating (Fig. 14F) but sharply defined, while the lower contact is sharp and planar only disrupted by larger bombs protruding into the base of Unit 10 from Unit 9. Unit 10 is continuous across the exposed EC canyon wall, extending another $\sim 70 \mathrm{~m}$ SSW until covered by alluvial canyon debris.
Fig. 16 Units of the middle cone stratigraphy. A-D Taken at AI1804, $\mathbf{E}$ and $\mathbf{F}$ taken at AI18-22. A Clast-supported, pumice dominated Unit 5 with graded bedding and a higher proportion of bombs near the boundary with Unit 6. B Units 6 (white ash unit) and 7 showing rapid changes in clast size and ash content within Unit 7. C Upper portion of unit and with rounded pumice clasts as shown in D. D Upper part of Unit 7 and ash-rich, indurated Unit 8. Pen $14 \mathrm{~cm}$ for scale. E Excavated pumice rich bed from Unit 9 sampled for density measurements. F Showing transition between middle and upper cone with Unit 10 denoted by dashed line.

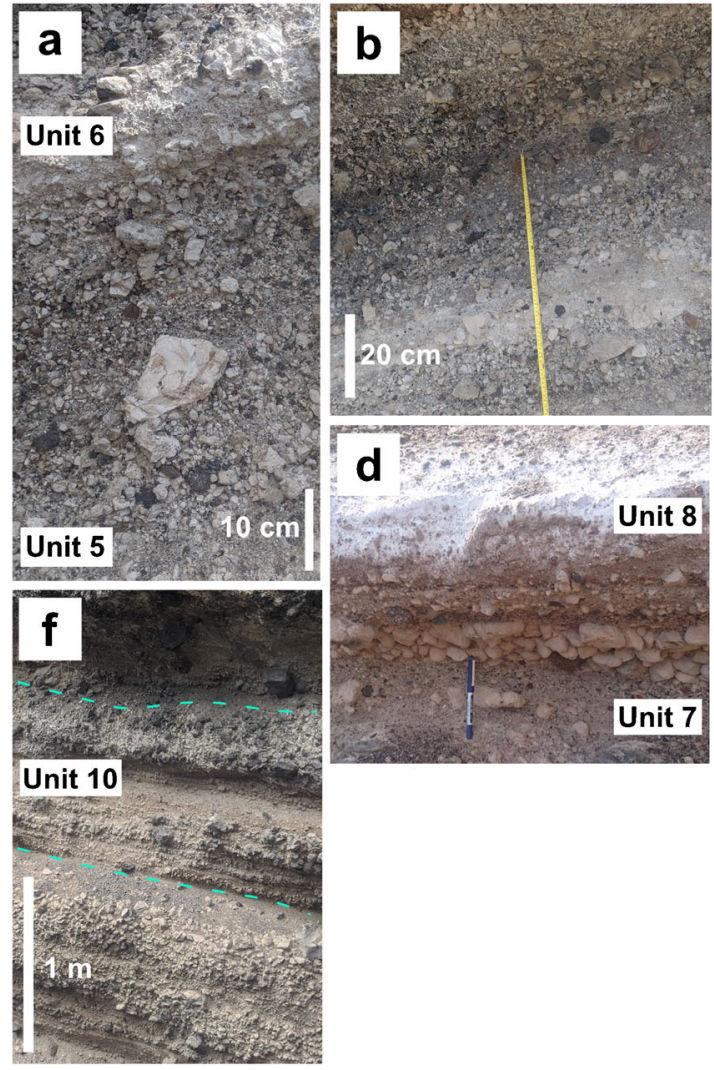

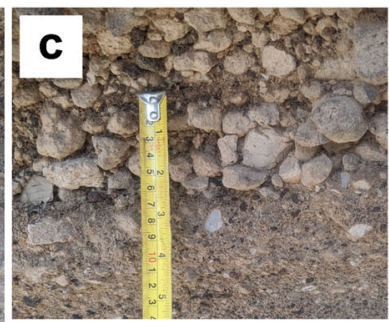

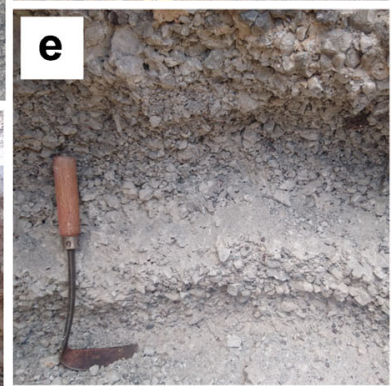




\section{Upper cone-proximal PDC deposits}

\section{Unit 11}

Unit 11 is a 12 -m-thick exposure of interbedded matrix and clast-supported beds sitting conformably on clastsupported pumice fall units exposed in the cliff face at the head of Rainbow Canyon (Fig. 17A) (locality AI1902 and 52). This unit is a condensed section equivalent to the inaccessible upper stratigraphy that thickens from 16 to $30 \mathrm{~m}$, approximately $\mathrm{N}-\mathrm{S}$ above unit 10 in the eastern face of Echo Canyon. At the Rainbow Canyon locality, the underlying clast-supported pumice falls are interpreted to be the condensed equivalent of Units $1-10$.

Matrix-supported beds contain 70-90\% ash, <20\% pumice, $\sim 10 \%$ obsidian and $<10 \%$ lithics (Fig. 17B). Pumice lapilli clasts are sub-rounded to rounded and have a modal clast size of $5 \mathrm{~cm}$ (Fig. 17C). Obsidian and obsidian breccia clasts (Fig. 17C) range from $<1$ to $15 \mathrm{~cm}$ in diameter and, like the pumice clasts, contain the same macrocryst population as the other EC units. Lithic clasts comprised a grey-black aphyric lava, red scoria and purple-black aphyric vesicular lava. The exteriors of these clasts are altered red. Lithic clasts are concentrated in lenses and have a modal diameter of $<1$ $\mathrm{cm}$. Matrix-supported beds are stratified, ash and fine lithic clasts define $\mathrm{cm}$-scale cross-stratification and pumice lapilli define decimetre-scale cross-stratification.

Clast-supported beds are massive and contain $<30 \%$ ash, $60 \%$ pumice, $10 \%$ obsidian and $10 \%$ lithic clasts. Pumice lapilli are sub-angular to sub-rounded and have a modal clast size of $5 \mathrm{~cm}$. Abundances of the five types of vesicle texture within pumice lapilli are macro-vesicular equant, 13\%; micro-vesicular equant, $30 \%$; macro-vesicular elongate, $16 \%$; micro-vesicular elongate, $27 \%$ and dense, $12 \%$. Juvenile obsidian and obsidian breccia clasts have a maximum diameter of $20 \mathrm{~cm}$. Lithic clasts have a modal diameter of $3 \mathrm{~cm}$ and comprised a grey-black aphyric lava, red scoria and purple-black aphyric vesicular lava. The exteriors of these clasts are altered red.

Across both matrix and clast-supported beds, breadcrust bombs, often with a black exterior, constitute $\sim 30 \%$ of all juvenile material: black interiors were observed in some bomb fragments. Maximum bomb diameter is $40 \mathrm{~cm}$. In Rainbow canyon, Unit 11 is directly overlain by both the dome and the OBP, which mantles the exposed stratigraphy of the upper cone beyond the domes' extent. In Echo Canyon, Unit 11 is directly overlain by the brecciated lava, apart from at the head of the canyon where Unit 12 cuts across Unit 11 and the middle cone.

\section{Unit 12}

Unit 12 is 15 -m-thick clast supported and dips $\sim 20^{\circ} \mathrm{SW}$ crosscutting the middle cone in the head of Echo Canyon (see Fig. 17D). Ninety-five percent of clasts are juvenile-55\% pumice lapilli/bombs and $40 \%$ lava fragments. Lithic clasts make up the remaining 5\%. Juvenile clasts are angular and contain the EC feldspar macrocryst population. All juvenile material is angular and modal pumice, and lava clast diameters decrease from 12 to $4.5 \mathrm{~cm}$ over the lower $7 \mathrm{~m}$ of the stratigraphy. In the middle of Unit 12 is a $3-m$-thick concentration of elongate pumice bombs up to $70 \mathrm{~cm}$ wide; here lava blocks are up to $1 \mathrm{~m}$ in diameter (Fig. 17E). The upper $7 \mathrm{~m}$ of Unit 12 is altered to white-grey, traces of pumice clasts that show a modal diameter of $6 \mathrm{~cm}$, maximum $50 \mathrm{~cm}$ (Fig. 17G, H). Juvenile lava clasts are less altered, angular and show banding; they range from 3 to $120 \mathrm{~cm}$ in diameter. The lithic clast population consists of a grey-black aphyric lava, red scoria and purple-black aphyric vesicular lava, modal lithic clast mirrors that of the juvenile pumice population throughout the unit. Unit 12 is laterally restricted, cropping out for approximately $35 \mathrm{~m}$ in the eastern face of Echo Canyon. The lower contact of Unit 12 is a sharp angular unconformity where it cuts across the underlying stratigraphy of the upper cone, while the upper contact with the OBP appears conformable, although was difficult to distinguish in outcrop due to high levels of alteration (Fig. 17G). The upper portions of the OBP appear to dip the same way as Unit 12 when viewed at a distance. 
Fig. 17 Field photos of upper cone deposits. A View towards AI19-02 looking approximately west at pale grey-yellow upper cone deposits (Unit 11) overlying felsic pyroclastics (black unit below) with OBP above. B Stratified ash-dominated portions of Unit 11, pumice clasts are rounded, and obsidian clasts can be deformed around pumice. C, D View of spatter-like portion of Unit 12 taken at AI19-23. E Close-up of dense, banded pumice spatter. F Clast-supported coarse pumice and lava clasts within Unit 12, hammer length $23 \mathrm{~cm}$ for scale. $\mathbf{G}$ and $\mathbf{H}$ Upper portion of Unit 12 , highly altered pumice clasts with large blocks of lava and pumice bombs standing out from surface. Orange unit at the top of $\mathrm{G}$ is the OBP.
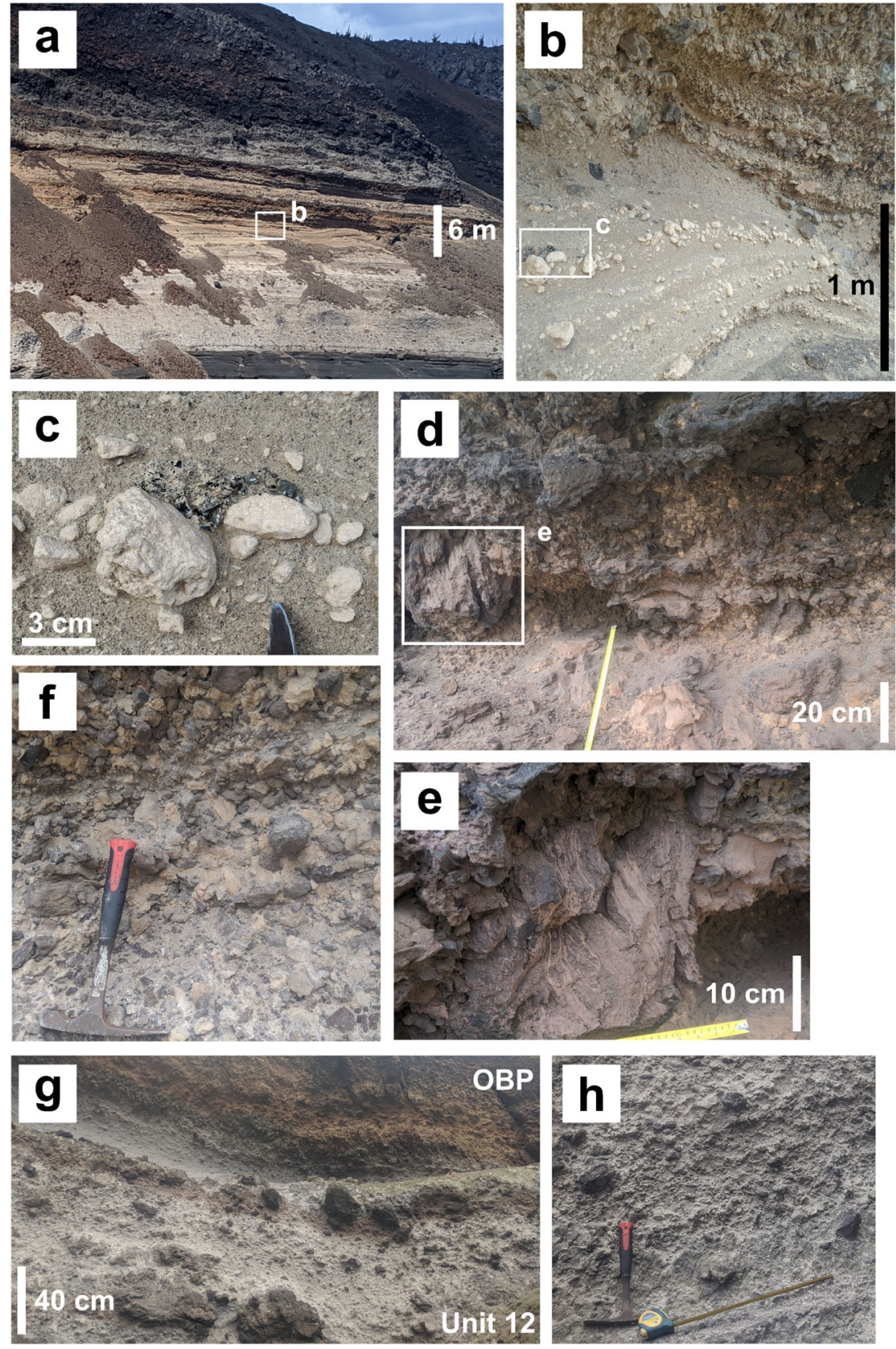

Type $A$ beds are between 3 and $7 \mathrm{~m}$ thick, matrix supported and generally massive with a very weathered exposed surface (Fig. 18A and B). The matrix comprises 30-40\% of each bed and is a medium sand grade mixture of black lithics ash and tiny pumice fragments. Pumice lapilli comprises $50-60 \%$ of each bed, are rounded and have a modal clast size of $3 \mathrm{~cm}$ and a maximum diameter of 4 $\mathrm{cm}$. Less than $10 \%$ of pumice clasts are bombs $>40 \mathrm{~cm}$. Abundances of the five pumice lapilli types were not quantified for this unit, but pumice lapilli are typically dense with dark banding. The lithic clast population comprised obsidian, purple-black lava, green-blue finely crystalline lava and a yellow, highly altered trachyte containing 1-mm feldspar phenocrysts. Lithic clasts have a 
modal diameter of $1 \mathrm{~cm}$, but large, sub-angular blocks of the lavas have a modal diameter of $30 \mathrm{~cm}$ and a maximum of $110 \mathrm{~cm}$. Type A beds form the lower contact with the underlying felsic pyroclastics, a sharp, planar boundary that it clearly visible all along the coastal outcrop (Fig. 18A). They are also the uppermost beds in the distal stratigraphy, overlain by re-worked material. There are 5 beds of this type in the NE-Bay distal PDC stratigraphy.

Type $B$ beds sit beneath type A in the stratigraphy and range from 20 to $64 \mathrm{~cm}$ thick: type $\mathrm{B}$ beds are pinkishwhite and indurated (Fig. 18A, C and D). Ash is generally the dominant component, but beds have varying proportions of 2-4-mm accretionary lapilli and $0.3-1-\mathrm{cm}$ angular lithic fragments (Fig. 18C-F). Accretionary lapilli compose $90-10 \%$ of beds, concentrated in cm-scale layers at lower concentrations. Rounded 2-mm pumice clasts comprise $<5 \%$ of each bed, as do Lithic clasts, concentrated in 1-2 cm layers. Lithic clasts are made up of black obsidian and blue-grey lavas. The base of type $B$ beds is always marked by a distinct pink $1-2-\mathrm{cm}$, fine ash layer. Thickness of these beds is continuous, and they extend along the full coastal exposure; there are 6 beds of this type in the Ne-Bay distal PDC stratigraphy.

$\underline{\text { Type } C}$ beds are $20-60 \mathrm{~cm}$ thick, massive and clast supported. Pumice lapilli make up 50\% of the beds, lithics < $30 \%$ and an ashy matrix comprising $10-30 \%$ of the beds (Fig. 18A and G). Beds are reversely graded. Pumice clasts are rounded and typically dense with banding, modal clast size grades from 0.3 to $4 \mathrm{~cm}$ up through each bed. Lithic clasts are sub-rounded with modal diameter grading upwards from 0.2 to $1 \mathrm{~cm}$. The fine, base of the bed is matrix rich and more welded than the coarse upper part. Contacts between type $\mathrm{C}$ units and the under/ overlying beds are sharp, planar and continuous across the coastal exposure.
Fig. 18 Field photos of EC distal PDC deposits at NE-Bay AI1946. A Overview of distal PDC deposits at the outcrop, approximately $25 \mathrm{~m}$ thick and showing contact with underlying felsic pyroclastics (dashed line). Person $175 \mathrm{~cm}$ for scale. Types A, $\mathrm{B}$ and $\mathrm{C}$ refer to typical stratigraphy as described in text. B Type A units, tape measure extended to $30 \mathrm{~cm}$ for scale. C and D Type B units. C White accretionary lapilli bed. D Ashrich bed with lenses of lithic fragments and accretionary lapilli. $\mathbf{E}$ and $\mathbf{F}$ Accretionary lapilli from $\mathrm{C}$ and D, respectively. G Clastsupported type $\mathrm{C}$ beds.
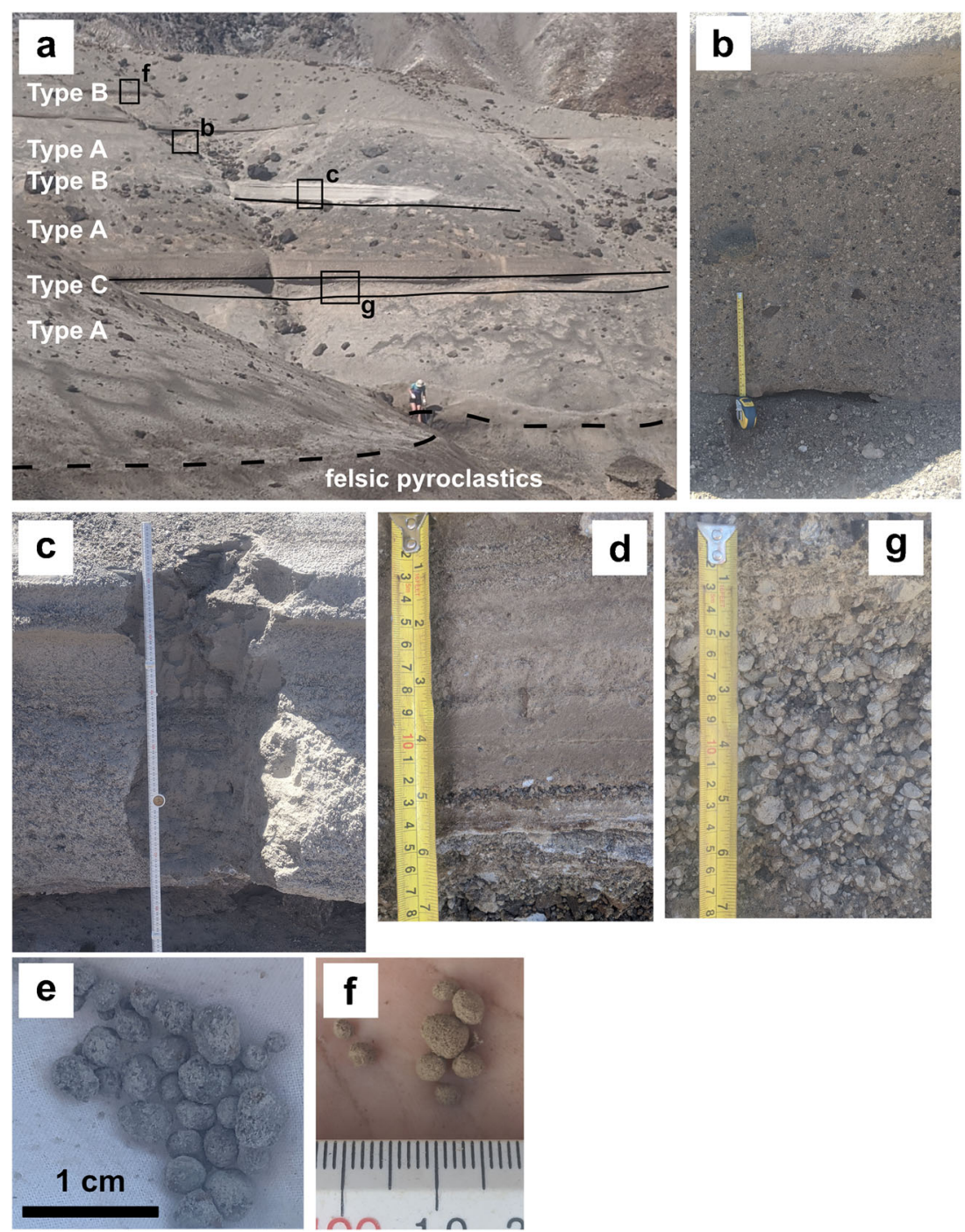


\section{Ariane site quarry and NE-Bay road}

Distal PDC deposits are exposed in road cuts along NEBay road and a quarry close to the Ariane ESA site (see Fig. 13 AI19-50 and AI19-13). The distal PDC deposit is composed of several beds with broad similarities to types A, B and C beds observed in the NE-Bay PDC deposits. The quarry face is approximately $6 \mathrm{~m}$ thick with the base covered by slumped material (Fig. 19A). Digging into this material revealed an approximately 55$\mathrm{cm}$-thick fine-grained remobilised unit consisting of blueish-grey lithic fragments and rounded pumice clasts up to $1 \mathrm{~cm}$ in size (Fig. 19B). This unit has complex cross-stratification and lenses of fine material. At the base of the remobilised unit is a layer of $>20 \mathrm{~cm}$ lithic blocks; the base of this was not excavated. The top of this unit is marked by a $1-\mathrm{cm}$-thick pale grey-brown fine-sand grade layer which has a sharp upper contact with the overlying PDC deposits.

The PDC deposits are approximately $3 \mathrm{~m}$ thick in both the quarry and roadside exposure and dip approximately $10-20^{\circ}$ towards the $\mathrm{N} / \mathrm{NNW}$. At the roadside exposure (AI19-50), the contact with underlying felsic pyroclastics is observed by digging down less than 30 $\mathrm{cm}$. In the quarry exposure there are 3 type $\mathrm{B}$ beds, 3 type $\mathrm{C}$ beds and 1 type $\mathrm{A}$ bed in a sequence $\mathrm{B}, \mathrm{A}, \mathrm{C}$, B, C, B and C from top to bottom (Fig. 19A).

The type A bed is approximately $1 \mathrm{~m}$ thick, matrix supported and massive with a heavily weathered surface. The matrix contains ash and $<1 \mathrm{~mm}$ black lithic fragments. As in the coastal deposits, pumice clasts are rounded and have a modal diameter of 2 $3 \mathrm{~cm}$, here though is an additional pumice population which is very dense, yellow in colour and contains $1 \mathrm{~mm}$ feldspar phenocrysts; these clasts are up to $6 \mathrm{~cm}$ in diameter. Lithic clasts are angular-subangular and include a black lava and a purple-red lava. Lithic clasts are typically $2-3 \mathrm{~cm}$ in diameter but also occur as large blocks with a maximum diameter of $102 \mathrm{~cm}$; these comprise less than $5 \%$ of the unit (Fig. 19C). The lower $40 \mathrm{~cm}$ of this bed is more welded than the upper part, but this affect pinches out round the quarry outcrop. The upper and lower contacts are sharp and planar. Above the type $\mathrm{A}$ bed is a $30 \mathrm{~cm}$ accretionary lapilli-rich type $\mathrm{B}$ bed; below it is a type $\mathrm{C}$ bed.

Type $B$ beds are $12-30 \mathrm{~cm}$ thick pink-brown indurated ash beds as seen in the coastal deposits. They lie conformably in the sequence (Fig. 19D). Within each bed, rounded pumice and lithic clasts from $0.1-1 \mathrm{~cm}$ diameter are concentrated in $1-\mathrm{cm}$ thick layers, usually 1 or 2 per bed. The uppermost type $\mathrm{B}$ bed, at the top of the sequence contains $>90 \%$ $3 \mathrm{~mm}$ accretionary lapilli. We correlate this approximately to the accretionary lapilli bed observed in the coastal PDC deposits.

Type $C$ beds are $10-60 \mathrm{~cm}$ thick, clast supported and exhibit reverse grading (Fig. 19E). These beds contain $90 \%$ pumice, which is rounded and has a modal diameter ranging from 0.1 to $3 \mathrm{~cm}$ from the base to the top of the unit. Vesicle textures in pumice clasts include macro-vesicular equant, elongate and densified. Angular, dense, yellow pumice clasts containing 1-mm feldspar phenocrysts comprise $20 \%$ of the pumice population and reach $4 \mathrm{~cm}$ diameter, only found in the upper portions of the beds. Lithic clasts comprise $10 \%$ of the unit and include a black-grey lava and a red vesicular lava; modal diameter is typically $0.1-3 \mathrm{~cm}$ with finest clasts in the base. In the coarser upper portion of the beds, mm-diameter rounded clasts form discontinuous irregular lenses up to $1 \mathrm{~cm}$ thick. 
Fig. 19 Field photographs of Echo Canyon (EC) distal pyroclastic density current (PDC) deposits at the Ariane Site Quarry AI19-13. A Overview of

exposure at the quarry site, person 175-cm tall for scale. B Close-up of re-worked stratified units at the base of the EC PDC deposits. $\mathbf{C}$ Type A beds containing large blocks and boulders, heavily weathered. D Close-up of type B and $\mathrm{C}$ beds, type $\mathrm{B}$ beds are pale competent ash beds, and type $\mathrm{C}$ beds contain pumice and are reversely graded as shown in $\mathbf{E}$.
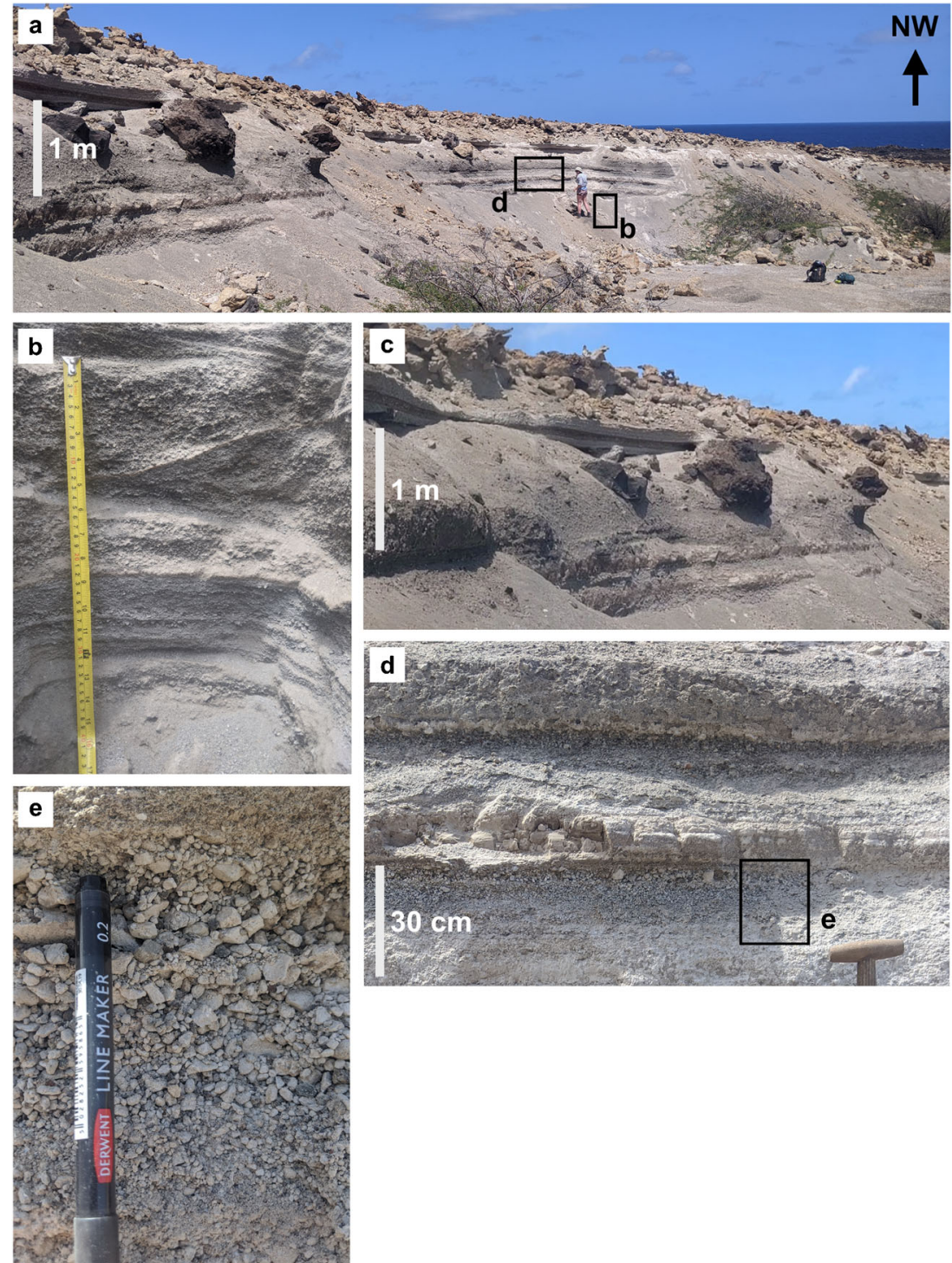


\section{Spire Beach}

The distal PDC deposits that crop out at the Spire Beach locality (AI18-73) are heavily weathered, and the exposure is gently sloping with several steps that cut into the stratigraphy where harder units stand out from the face (Fig. 20A). The composition of units in the weathered flat surface was difficult to define, and so key descriptions were limited to cut faces. The dominant lithologic characteristics are very similar to that of the matrix supported (type A) beds observed at the NEBay coastal and quarry outcrops, with clast-supported (type C) beds forming a minor constituent in the stratigraphy, no accretionary lapilli are found here. The PDC deposits dip approximately $20^{\circ}$ towards the ENE: the exposed sequence is approximately $7 \mathrm{~m}$ thick.

Approximately 2-3-m-thick matrix-supported beds dominate the stratigraphy: the matrix is a brown-purple ash which weathers to pale grey. The beds are comprised of $80 \%$ matrix, $10 \%$ pumice clasts, $5 \%$ obsidian breccia and dense endmember VVLP clasts approximately and 5\% lithic clasts. Pumice clasts are sub-angular-rounded with a modal diameter of $1 \mathrm{~cm}$ : pumice bombs and fragments can be greater than $7 \mathrm{~cm}$ (Fig. $20 \mathrm{~B}$ and C). Pumice clasts are generally dense and micro-vesicular, while pumice bombs are the angular banded type. The dense clasts-obsidian breccia, dense
VVLP clasts and other lithic clasts, range from angular $3-\mathrm{mm}$ fragments and rounded $2-3-\mathrm{cm}$ clasts to subangular-angular blocks from 0.3 to $1 \mathrm{~m}$ in diameter. The obsidian in obsidian breccia clasts is heavily altered and easily friable; a variety of lithic and pumice clasts which range from $1 \mathrm{~cm}$ to 10 's of $\mathrm{cm}$ in diameter are held together by the obsidian. Lithic clasts include a purple vesicular lava with altered 3-mm feldspar phenocrysts and a red non-vesicular lava. Discontinuous pumice rich lenses, $4-10 \mathrm{~cm}$ thick, pinch in and out across the beds. Matrix-supported beds appear to be more strongly welded than clast-supported beds; contacts between beds are marked by a $1-2 \mathrm{~cm}$ ash layer and are sharp and planar as a result.

Clast-supported beds are typically $10-30 \mathrm{~cm}$ thick, best exposed in steps in the outcrop where outer surfaces are broken away. The beds are made up of $75 \%$ pumice lapilli, $10 \%$ pumice bombs, $10 \%$ obsidian breccia and 5\% other lithic clasts (Fig. 20D). Pumice clasts are angular with a modal diameter of $3 \mathrm{~cm}$ and a maximum of 6 $\mathrm{cm}$. Dense, banded pumice bombs are up to $40 \mathrm{~cm}$ in diameter (Fig. 20E). Obsidian fragments are as fine as 3 $\mathrm{mm}$, but obsidian breccia blocks are typically $20-30 \mathrm{~cm}$ in diameter (Fig. 20F). Other lithic clasts are of the same types as described in matrix-supported units and can be up to $70 \mathrm{~cm}$ in diameter. Clast-supported beds show some subtle reverse grading amongst the pumice lapilli, slightly overprinted by the bomb population. 
Fig. 20 Photos of distal PDC deposits at Spire Beach, AI18-73. A Exposure of heavily weathered PDC deposits at AI18-73. B Fresh cut face through type A beds showing matrix supported pumice clasts and lithic fragments. C Weathered top surface of type A beds shown in $\mathbf{B}$. D and $\mathbf{E}$ Altered type $C$ clast-supported beds with pumice bombs. F Example of obsidian breccia at Spire Beach, lithic clasts and pumice fragments within banded obsidian.
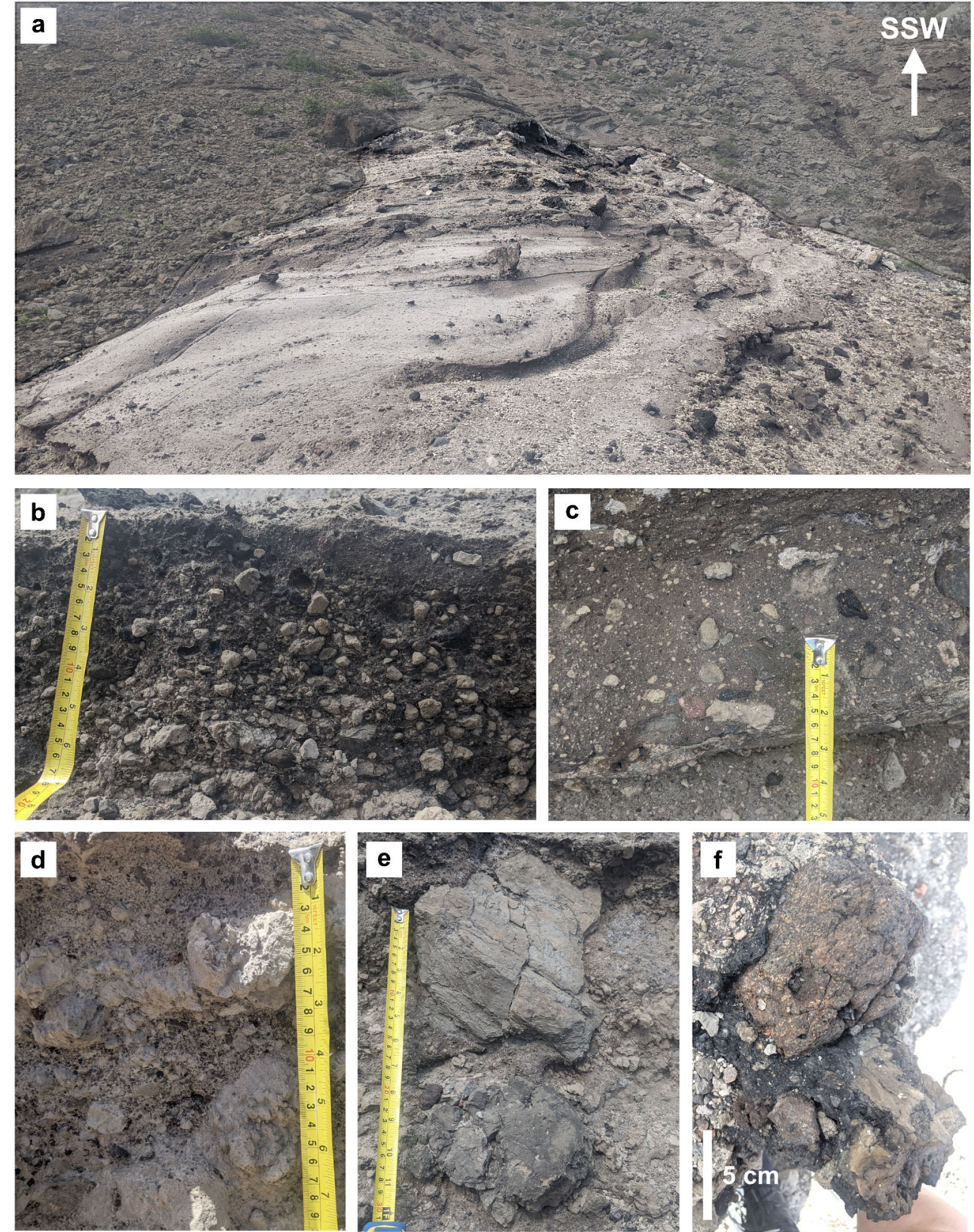


\section{Post cone units}

\section{Dome}

The dome is a blue-grey, 30-40-m-thick brecciated porphyritic trachyte lava cropping out in direct contact with PDC deposits at Rainbow Canyon and Spire Beach (Fig. 21A). The crystal population is as described for all EC eruption deposits (see Appendix 2. Petrography): feldspar and clinopyroxene macrocrysts constitute 3-5\% of the dome. Groundmass crystallinity is heterogeneous in thin section but up to $70 \%$. Vesicles up to $1 \mathrm{~cm}$ diameter comprise $<10 \%$ of the dome and often contain macrocrysts. The dome is extensively brecciated and heterogeneously altered to white clays (Fig. 21B): unaltered blocks are usually $\leq 1 \mathrm{~m}$ in diameter and exhibit mm-cm flow banding (Fig. 21C).

\section{Lava flow}

The lava flow is a purple-grey, 7.5-10-m-thick brecciated porphyritic trachyte lava (Fig. 21D). The lava overlies the pumice cone at Echo Canyon (AI18-20) and the dome at Rainbow Canyon (AI19-02, 52) and Spire Beach (Ai18-73). The macrocryst population is the same as that of the dome. Groundmass crystallinity in thin section is heterogeneous with regions of $>30 \%$ crystals. Vesicles up to $0.5 \mathrm{~cm}$ diameter comprise $<10 \%$ of the lava flow. The lava flow is brecciated, but clays produced by alteration are pink. Coherent, un-altered regions are aligned parallel to flow direction, which is approximately north (Fig. 21E and F). In thin section, complex mm-cm scale banding is observed.

\section{OBP fall}

The OBP is a $3-10-\mathrm{m}$-thick clast-supported pumice fall that thickens to the SE. The dip of the OBP is typically $\sim 30^{\circ}$, the direction varying from SSE to NNW depending on the underlying topography of the EC sequence (Fig. 21G). Juvenile material comprises $>95 \%$ of the unit, including approximately 5\% obsidian; pumice clasts are dominated by bombs. Pumice clasts are angular with a modal diameter of $10 \mathrm{~cm}$. Abundances of the five types of vesicle texture within pumice lapilli are macro-vesicular equant, 36\%; micro-vesicular equant, $33 \%$; macro-vesicular elongate, $3 \%$ micro-vesicular elongate, $9 \%$ and dense, 18\%. Breadcrust bombs are dominant with a maximum diameter of $45 \mathrm{~cm}$. Many pumice clasts are pale orange/pink and have dark thermally altered cores. Obsidian fragments range from 2 to $45 \mathrm{~cm}$ in diameter; larger clasts/blocks are often rounded-sub-rounded (Fig. $21 \mathrm{H}$ ). Contacts between the upper pumice fall and underlying lavas are sharp. The contact with Unit 12 of the upper cone, however, is gradational and difficult to discern due to alteration of clasts and outcrop accessibility (Fig. 15G). 
Fig. 21 Images of Echo Canyon (EC) post-cone deposits. A

Outcrop of the dome at AI18-33. B Close-up of weathered regions with EC macrocrysts of

clinopyroxene and plagioclase. $\mathbf{C}$ Sampled fragment of less altered dome lava showing $\mathrm{mm}-\mathrm{cm}$ banding, macrocrysts and vesicles. D The brecciated lava in outcrop showing brecciation and alteration to pink clays and banding of un-altered blocks. $\mathbf{E}$ and $\mathbf{F}$ Close-up of banding picked out by altered and un-altered regions in brecciated lava; in $\mathbf{F}$, hammer handle is $20 \mathrm{~cm}$ for scale. G View overlooking NE bay showing OBP dipping approximately $30^{\circ}$ towards the NE overlying the brecciated lava. H Obsidian bomb within coarse pumice of the OBP.
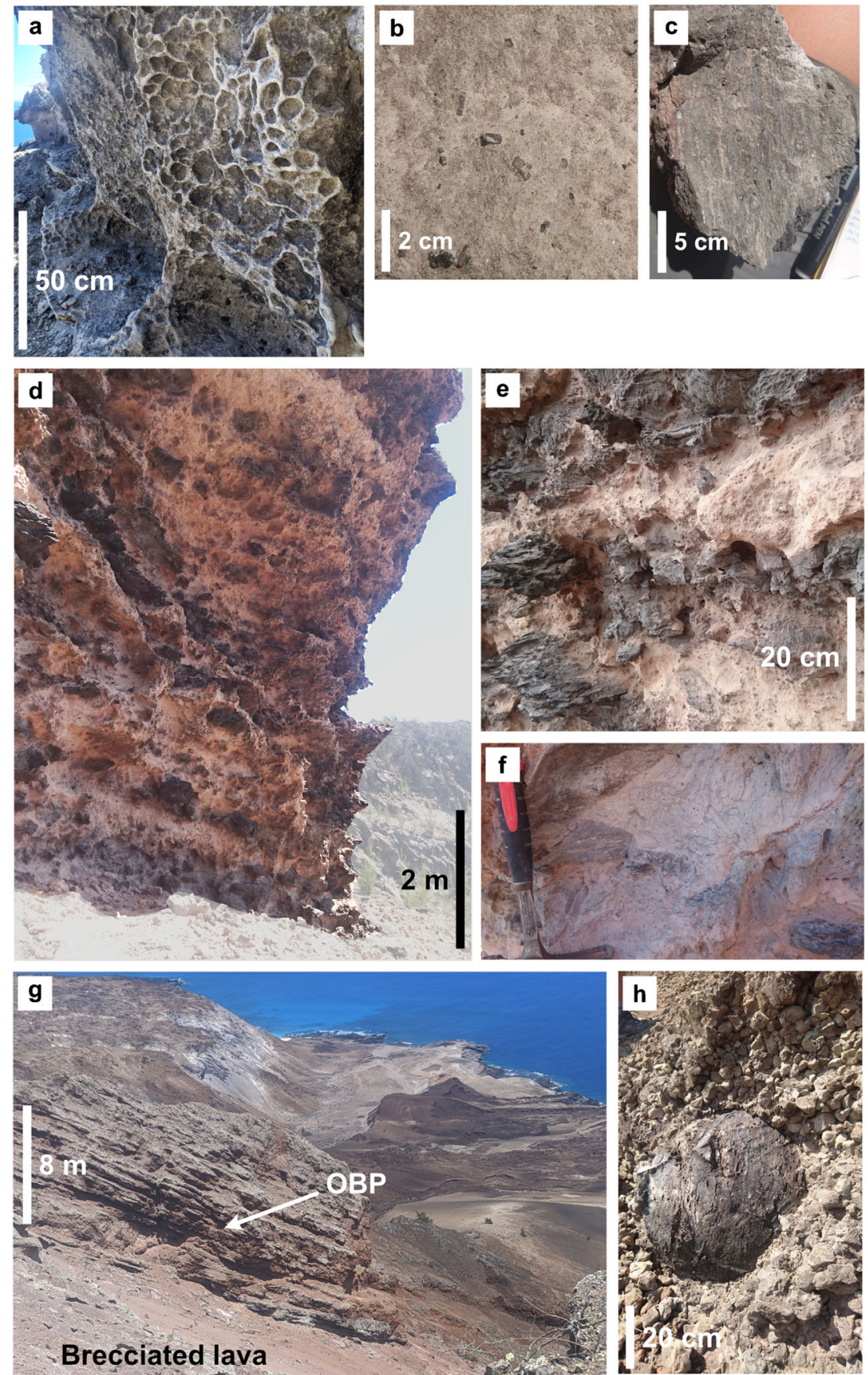


\section{Appendix 2 Petrography}

The juvenile components of the EC eruption contain 38-mm-alkali feldspar and pyroxene crystal intergrowths: individual crystals are $2-4 \mathrm{~mm}$ and, in places, fragmented (Fig. 22A and D). Within pumice clasts, crystals $\geq 2 \mathrm{~mm}$ comprise $<1$ modal $\%$, in lavas up to 5 modal \%: intact intergrowths and $>3 \mathrm{~mm}$ crystals are most abundant in lavas and obsidian. Euhedralsubhedral alkali-feldspar crystals of 1-2 $\mathrm{mm}$ are present, alongside 150-700 $\mu \mathrm{m}$ fragmented and whole alkali- feldspar, quartz, orthopyroxene, clinopyroxene and olivine (Fig. 22A-E): these crystals constitute $<2 \%$ of all juvenile material. Alkali-feldspar microlites of $<10$ $200 \mu \mathrm{m}$ generally have abundances of $1-2 \%$ in pumice clasts, $70 \%$ in the dome and $30 \%$ in the lava flow. Some OBP clasts, however, contain clearly defined regions of up to $30 \%$ alkali-feldspar microlites (Fig. 22F). Microlites are distorted by large vesicles in pumice clasts and can be aligned parallel to banding in lavas. Disequilibrium textures are rare (Fig. 22A-E, G-I), but some pumice clasts contain fragments of crystal rich material containing crystal remnants.
Fig. 22 Phenocrysts

Characteristic crystal population of Echo Canyon (EC) products. A and D 3-mm alkali-feldspar (afs) crystal clots with clinopyroxene (cpx) and zircon (Zr) inclusions. A From pumice sample with sharp edges; D within lava-more rounded edges, groundmass is highly microcrystalline. B and $\mathbf{C}$ Smaller euhedral afs population $\sim 500 \mu \mathrm{m}$ (B from Unit 3 pumice), $\mathbf{C}$ with rounded edges (from orange-brown pumice (OBP)) $\mathbf{A}$ E Secondary electron images collected on a Zeiss Gemini 300 SEM at the University of East Anglia, UK. F Regions of high and low afs microlite abundance within clast from the OBP.

Backscattered electron image collected on a FEI quanta 650 FEG SEM at the Natural History Museum, London, UK. G Thin section of obsidian breccia (obs) with clasts of obsidian, ashy matrix and fragments of pumice (ves melt). EC afs present in clasts and matrix. $\mathbf{H}$ and I Images of EC 3-mm afs crystals within obsidian in cross-polarised light (XP).
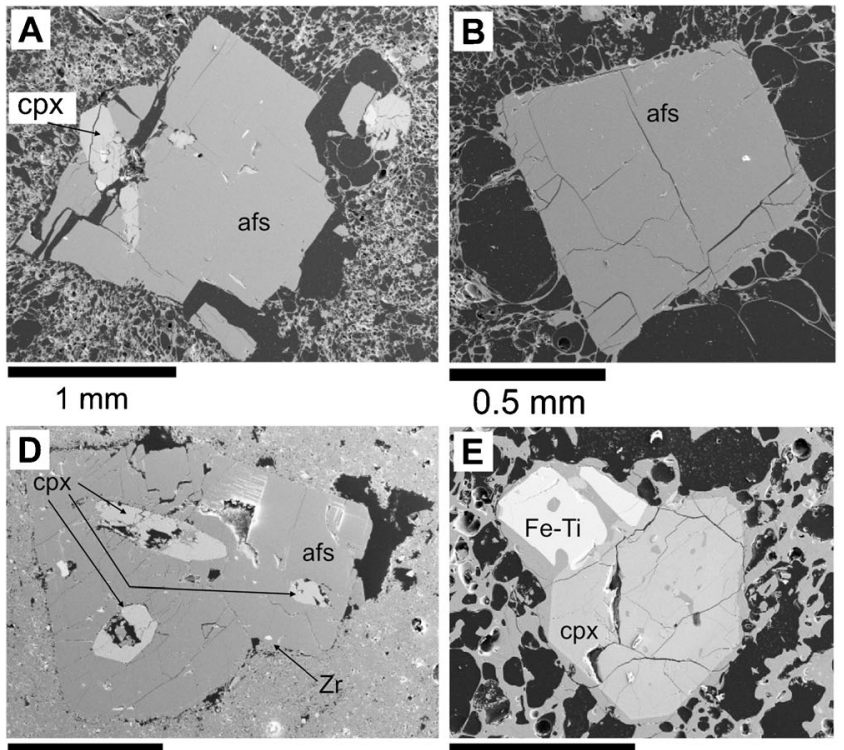

$1 \mathrm{~mm}$

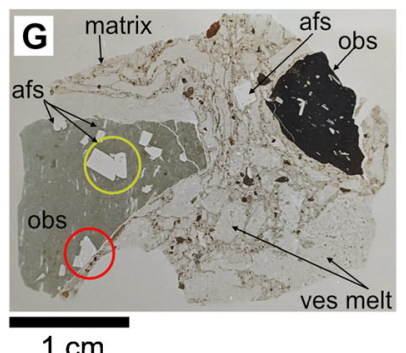

$1 \mathrm{~cm}$
$0.5 \mathrm{~mm}$

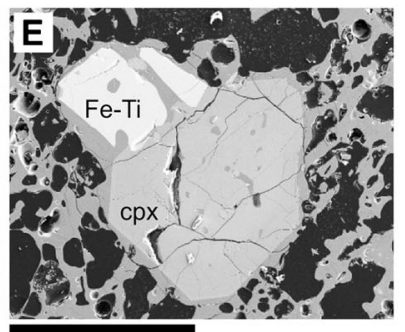

$0.5 \mathrm{~mm}$

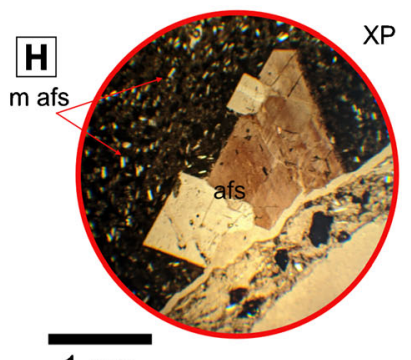

$1 \mathrm{~mm}$

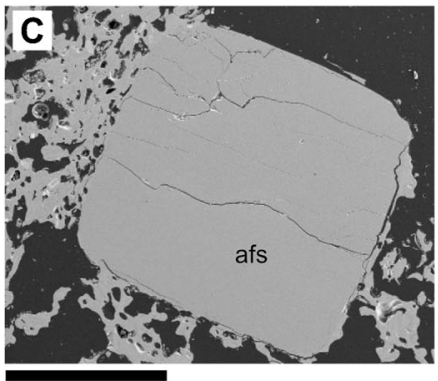

$0.5 \mathrm{~mm}$

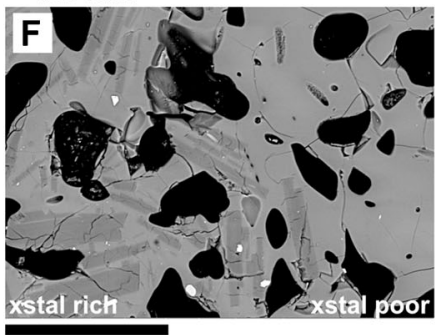

$100 \mu \mathrm{m}$

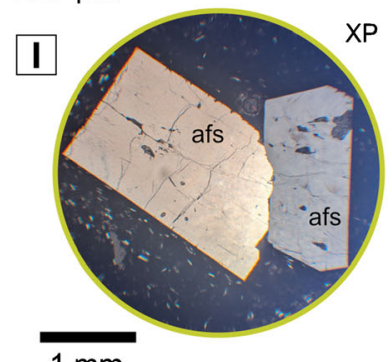

$1 \mathrm{~mm}$ 


\section{Appendix 3 SEM Image collection methods}

\section{SEM imagery}

A total of 27 clasts were selected for thin section from the explosive eruption products. In order to attain a representative sample, we considered (1) the textural heterogeneity of each unit, (2) the bulk vesicularity of each selected clast relative to the BVD of the unit, (3) how each textural group influences the BVD and (4) unusual textural features. The selected clasts represent a spread of textural type and bulk density within and between each sampled unit as well as textural extremes. One thin section was taken from each of the post-cone lavas. Polished thin sections were then carbon coated and backscattered and secondary electron images collected on an FEI Quanta 650 FEG at the Natural History Museum, London, UK, a Zeiss Gemini sigma $300 \mathrm{VP}$ at the Zeiss facility in Cambridge, UK and a Zeiss Gemini 300 SEM at the University of East Anglia, UK.

Supplementary Information The online version contains supplementary material available at https://doi.org/10.1007/s00445-021-01480-1.

Acknowledgements The authors wish to thank the Ascension Island Government, Conservation Department and residents of Ascension Island and Rebecca Winstanley for their support and assistance during fieldwork. BVD was supported by the Natural Environment Research Council through the EnvEast Doctoral Training Partnership (grant number NE/1002582/1). JHS acknowledges funding from the European Union's Horizon 2020 research and innovation programme under the Marie Skłodowska-Curie grant agreement No. 749611. Funding from the Marie Skłodowska-Curie project supported the whole-rock ICP analyses. We thank reviewers Ben Andrews and anonymous reviewer for their prompt reviews and constructive comments which helped to improve this manuscript, and we thank Laura Pioli for editorial handling.

Code availability Not applicable.

Author contribution Bridie V Davies contributed to the conceptualization of ideas and methodology, sample collection and analysis and visualisation of data and wrote the manuscript. Richard J Brown and Jane $\mathrm{H}$ Scarrow contributed to data collection during fieldwork. All authors contributed to the conceptualisation of ideas and the writing process and provided feedback on data visualisation.

Funding BVD is funded by the Natural Environment Research Council through the EnvEast Doctoral Training partnership (grant number NE/ $1002582 / 1)$.

Data availability Additional data associated with this manuscript can be found in the British Geological Survey NGDC database here: https:// webapps.bgs.ac.uk/services/ngdc/accessions/index.html?simpleText= 167249\#item167249.

\section{Declarations}

Ethics approval Not applicable.
Consent to participate Not applicable.

Consent for publication All authors consent to publication.

Conflicts of interest The authors declare no competing interests.

Open Access This article is licensed under a Creative Commons Attribution 4.0 International License, which permits use, sharing, adaptation, distribution and reproduction in any medium or format, as long as you give appropriate credit to the original author(s) and the source, provide a link to the Creative Commons licence, and indicate if changes were made. The images or other third party material in this article are included in the article's Creative Commons licence, unless indicated otherwise in a credit line to the material. If material is not included in the article's Creative Commons licence and your intended use is not permitted by statutory regulation or exceeds the permitted use, you will need to obtain permission directly from the copyright holder. To view a copy of this licence, visit http://creativecommons.org/licenses/by/4.0/.

\section{References}

Ablay GJ, Martİ J (2000) Stratigraphy, structure, and volcanic evolution of the Pico Teide-Pico Viejo formation, Tenerife, Canary Islands. JVGR 103(1-4):75-208. https://doi.org/10.1016/S0377-0273(00) 00224-9

Alfano F, Bonadonna C, Gurioli L (2012) Insights into eruption dynamics from textural analysis: the case of the May, 2008, Chaitén eruption. Bull Volcanol 74(9):2095-2108. https://doi.org/10.1007/s00445012-0648-3

Andrews BJ, Dufek J, Ponomareva V (2018) Eruption dynamics and explosive-effusive transitions during the $1400 \mathrm{cal} \mathrm{BP}$ eruption of Opala volcano, Kamchatka, Russia. JVGR 356:316-330. https:// doi.org/10.1016/j.jvolgeores.2018.02.019

Arzilli F, Carroll MR (2013) Crystallization kinetics of alkali feldspars in cooling and decompression-induced crystallization experiments in trachytic melt. Contrib Mineral Petrol 166(4):1011-1027. https:// doi.org/10.1007/s00410-013-0906-1

Atkins FB, Baker PE, Bell JD, Smith DGW (1964) Oxford expedition to Ascension Island, 1964. Nature 204(4960):722-724. https://doi.org/ $10.1038 / 204722 \mathrm{a} 0$

Blong R (1994) The Rabaul eruption, 1994. Aust Geogr 25(2):186-190. https://doi.org/10.1080/00049189408703118

Buck MD, Briggs RM, Nelson CS (1981) Pyroclastic deposits and volcanic history of Mayor Island. N Z J Geol Geophys 24(4):449-467

Capaldi G, Civetta L, Gasparini P (1976) Volcanic history of the Island of Ischia (South Italy). Bull Volcanol 40(1):11-22. https://doi.org/10. 1007/BF02599826

Cas RAF, Wright JV (1996) Three types of pyroclastic deposits and their eruptions: an introduction. In: Volcanic Successions Modern and Ancient: A geological approach to processes, products and successions, 5th edn. Chapman \& Hall, London, pp 94-126

Cashman KV, Mangan MT (1994) Physical aspects of magmatic degassing II. Constraints on vesiculation processes from textural studies of eruptive products. In: Carroll MR, Holloway JR (eds) Volatiles in Magmas. Mineralogical Society of America, Washington DC, pp 447-478. https://doi.org/10.1515/ 9781501509674-018

Cassidy M, Manga M, Cashman K, Bachmann O (2018) Controls on explosive-effusive volcanic eruption styles. Nat Commun 9(2839): 2839. https://doi.org/10.1038/s41467-018-05293-3

Castro JM, Bindeman IN, Tuffen H, Schipper I (2014) Explosive origin of silicic lava: textural and $\delta \mathrm{D}-\mathrm{H} 2 \mathrm{O}$ evidence for pyroclastic 
degassing during rhyolite effusion. Earth Planet Sci Lett 405:52-61. https://doi.org/10.1016/j.epsl.2014.08.012

Chamberlain KJ, Barclay J, Preece K, Brown RJ, Davidson JP, EIMF (2016) Origin and evolution of silicic magmas at ocean islands: perspectives from a zoned fall deposit on Ascension Island, South Atlantic. J Volcanol Geotherm Res 327:349-360. https://doi.org/10. 1016/j.jvolgeores.2016.08.014

Chamberlain KJ, Barclay J, Preece KJ, Brown RJ, Davidson JP (2019) Lower crustal heterogeneity and fractional crystallization control evolution of small-volume magma batches at Ocean Island Volcanoes (Ascension Island, South Atlantic). J Petrol 60(8): 1489-1522. https://doi.org/10.1093/petrology/egz037

Chamberlain KJ, Barclay J, Preece K, Brown R, McIntosh I, EIMF (2020) Deep and disturbed: conditions for formation and eruption of a mingled rhyolite at Ascension Island south Atlantic. Volcanica 3(1)139-153. https://doi.org/10.30909/vol.03.01.139153

Cioni R, Bertagnini A, Santacroce R, Andronico D (2008) Explosive activity and eruption scenarios at Somma-Vesuvius (Italy): towards a new classification scheme. J Volcanol Geotherm Res 178(3):331346. https://doi.org/10.1016/j.jvolgeores.2008.04.024

Cioni R, Pistolesi M, Rosi M (2015) Plinian and subplinian eruptions. In: Sigurdsson H (ed) The Encyclopedia of Volcanoes, 2nd edn. Academic, Cambridge, pp 519-535. https://doi.org/10.1016/b9780-12-385938-9.00029-8

Clarke B (2020) Post-caldera eruptions and pyroclastic density current hazard in the Main Ethiopian Rift. PhD thesis, University of Edinburgh. https://doi.org/10.7488/era/153

Cole PD, Queiroz G, Wallenstein N, Gaspar JL, Duncan AM, Guest JE (1995) An historic subplinian/phreatomagmatic eruption: the 1630 AD eruption of Furnas volcano, Saõ Miguel, Azores. J Volcanol Geotherm Res 69(1-2):117-135. https://doi.org/10.1016/03770273(95)00033-X

Cole PD, Guest JE, Queiroz G, Wallenstein N, Pacheco JM, Gaspar JL, Ferreira T, Duncan AM (1999) Styles of volcanism and volcanic hazards on Furnas volcano; Sao Miguel, Azores. J Volcanol Geotherm Res 92(1-2):39-53. https://doi.org/10.1016/S03770273(99)00066-9

Croasdale R, Walker GPL, Booth B (1978) A quantitative study of five thousand years of volcanism on Sao Miguel, Azores. Philos Trans R Soc Lond Ser A, Math Phys Sci 288(1352):271-319. https://doi.org/ 10.1098/rsta.1978.0018

DavÌ M, De Rosa R, Donato P, Sulpizio R (2011) The Lami pyroclastic succession (Lipari, Aeolian Islands): a clue for unravelling the eruptive dynamics of the Monte Pilato rhyolitic pumice cone. J Volcanol Geotherm Res 201:285-300. https://doi.org/10.1016/j.jvolgeores. 2010.09.010

Dellino P, La Volpe L (1995) Fragmentation versus transportation mechanisms in the pyroclastic sequence of Monte Pilato-Rocche Rosse (Lipari, Italy). J Volcanol Geotherm Res 64(3-4):211-231. https:// doi.org/10.1016/0377-0273(94)00084-T

Deniel C, Boivin P, Miallier D, Gerbe MC (2020) Multi-stage growth of the trachytic lava dome of the Puy de Dôme (Chaîne des Puys, France). Field, geomorphological and petro-geochemical evidence. J Volcanol Geotherm Res 396:106749. https://doi.org/10.1016/j. jvolgeores.2019.106749

Di Genova D, Romano C, Hess K-U, Vona A, Poe BT, Giordano D, Dingwell DB, Behrens H (2013) The rheology of peralkaline rhyolites from Pantelleria Island. J Volcanol Geotherm Res 249:201216. https://doi.org/10.1016/j.jvolgeores.2012.10.017

Fanara S, Behrens H, Zhang Y (2013) Water diffusion in potassium-rich phonolitic and trachytic melts. Chem Geol 346:49-161. https://doi. org/10.1016/j.chemgeo.2012.09.030

Fowler AC, Scheu B, Lee WT, McGuinness MJ (2010) A theoretical model of the explosive fragmentation of vesicular magma. Proc $\mathrm{R}$ Soc A Math Phys Eng Sci 466(2115):731-752. https://doi.org/10. 1098/rspa.2009.0382
Gardner JE, Llewellin EW, Watkins JM, Befus KS (2017) Formation of obsidian pyroclasts by sintering of ash particles in the volcanic conduit. Earth Planet Sci Lett 459:252-263. https://doi.org/10.1016/j. epsl.2016.11.037

Giordano D, Romano C, Papale P, Dingwell DB (2004) The viscosity of trachytes, and comparison with basalts, phonolites, and rhyolites. Chem Geol 213(1-3):49-61. https://doi.org/10.1016/j.chemgeo. 2004.08.032

Giordano D, Nichols ARL, Dingwell DB (2005) Glass transition temperatures of natural hydrous melts: a relationship with shear viscosity and implications for the welding process. J Volcanol Geotherm Res 142(1-2):105-118. https://doi.org/10.1016/j.jvolgeores.2004.10. 015

Giordano D, Russell JK, Dingwell DB (2008) Viscosity of magmatic liquids: a model. Earth Planet Sci Lett 271(1-4):123-134. https:// doi.org/10.1016/j.eps1.2008.03.038

Google Earth V7.3.3.7721 (2006) Ascension Island, South Atlantic. 7०55'44.74”S 1419'26.42” W, Eye alt $4.72 \mathrm{~km}$. Maxar Technologies 2020. http://www.earth.google.com. Accessed 18 Nov 2020

Google Earth V7.3.3.7721 (2016) Rabaul, Papua New Guinea. 414 $58.14 \mathrm{~S} 1521117.37 \mathrm{E}$, Eye alt $11.4 \mathrm{~km}$. Maxar Technologies 2020. http://www.earth.google.com. Accessed 11 Aug 2020

Harris C (1983) The petrology of lavas and associated plutonic inclusions of Ascension Island. J Petrol 24(4):424-470. https://doi.org/10. 1093/petrology/24.4.424

Heap MJ, Tuffen H, Wadsworth FB, Reuschlé T, Castro JM, Schipper CI (2019) The permeability evolution of tuffisites and implications for outgassing through dense rhyolitic magma. J Geophys Res Solid Earth 124(8):8281-8299. https://doi.org/10.1029/2018JB017035

Hernando LR, Petrinovic IA, D’Elia L, Guzmán S, Páez GN (2019) Postcaldera pumice cones of the Payún Matrú caldera, Payenia, Argentina: morphology and deposits characteristics. J S Am Earth Sci 90:453-462. https://doi.org/10.1016/j.jsames.2018.12.017

Hofmann AW (1988) Chemical differentiation of the Earth: the relationship between mantle, continental crust, and oceanic crust. Earth Planet Sci Lett 90(3):297-314. https://doi.org/10.1016/0012821X(88)90132-X

Houghton BF, Wilson CJN (1989) A vesicularity index for pyroclastic deposits. Bull Volcanol 51(6):451-462. https://doi.org/10.1007/ BF01078811

Houghton BF, Wilson CJN, Weaver SD (1985) Strombolian deposits at Mayor Island: "Basaltic" eruption styles displayed by a peralkaline volcano. NZ Geol Surv Rec 8:45-51

Houghton BF, Weaver SD, Wilson CJN, Lanphere MA (1992) Evolution of a Quaternary peralkaline volcano: Mayor Island New Zealand. J Volcanol Geotherm Res 51(3):217-236. https://doi.org/10.1016/ 0377-0273(92)90124-V

Houghton BF, Wilson CJN, Fierstein J, Hildreth W (2004) Complex proximal deposition during the Plinian eruptions of 1912 at Novarupta, Alaska. Bull Volcanol 66:95-133. https://doi.org/10. 1007/s00445-003-0297-7

Houghton BF, Carey RJ, Cashman KV, Wilson CJN, Hobden BJ, Hammer JE (2010) Diverse patterns of ascent, degassing, and eruption of rhyolite magma during the $1.8 \mathrm{ka}$ Taupo eruption, New Zealand: Evidence from clast vesicularity. JVGR 195(1):31-47. https://doi.org/10.1016/j.jvolgeores.2010.06.002

Houghton BF, Swanson DA, Rausch J, Carey RJ, Fagents SA, Orr TR (2013) Pushing the volcanic explosivity index to its limit and beyond: constraints from exceptionally weak explosive eruptions at Kīlauea in 2008. Geology 416:107284. https://doi.org/10.1016/j. jvolgeores.2021.107284

Hughes EC, Neave DA, Dobson KJ, Withers PJ, Edmonds M (2017) How to fragment peralkaline rhyolites: observations on pumice using combined multi-scale 2D and 3D imaging. J Volcanol 
Geotherm Res 336:179-191. https://doi.org/10.1016/j.jvolgeores. 2017.02.020

Hutchison W, Pyle DM, Mather TA, Yirgu G, Biggs J, Cohen BE, Barfod DN, Lewi E (2016) The eruptive history and magmatic evolution of Aluto volcano: new insights into silicic peralkaline volcanism in the Ethiopian rift. J Volcanol Geotherm Res 328:9-33. https://doi.org/ 10.1016/j.jvolgeores.2016.09.010

Jeffery AJ, Gertisser R, O’Driscoll B, Pacheco JM, Whitley S, Pimentel A, Self S (2016) Temporal evolution of a post-caldera, mildly peralkaline magmatic system: Furnas volcano, São Miguel, Azores. Contrib Mineral Petrol 171(5):42. https://doi.org/10.1016/ j.jvolgeores.2016.09.010

Jeffery AJ, Gertisser R, Self S, Pimentel A, O'Driscoll B, Pacheco JM (2018) Petrogenesis of the Peralkaline Ignimbrites of Terceira, Azores. J Petrol 58(12):2365-2402. https://doi.org/10.1093/ petrology/egy012

Jicha BR, Singer BS, Valentine MJ (2013) 40Ar/39Ar geochronology of subaerial Ascension Island and a re-evaluation of the temporal progression of basaltic to rhyolitic volcanism. J Petrol 54(12):25812596. https://doi.org/10.1093/petrology/egt058

Kar A, Weaver B, Davidson J, Colucci M (1998) Origin of differentiated volcanic and plutonic rocks from Ascension Island, South Atlantic Ocean. J Petrol 39(5):1009-1024. https://doi.org/10.1093/petroj/39. 5.1009

Katsui Y, Katz HR (1967) Lateral fissure eruptions in the southern Andes of Chile. J Fac Sci, Hokkaido Univ Ser 4, Geol Mineral 13(4):433$448 \mathrm{http} / / \mathrm{hdl}$.handle.net/2115/35970

Klug C, Cashman KV (1996) Permeability development in vesiculating magmas: implications for fragmentation. Bull Volcanol 58(2-3): 87-100. https://doi.org/10.1007/s004450050128

Lange RA, Carmichael IS (1987) Densities of Na2O-K2O-CaO-MgO$\mathrm{FeO}-\mathrm{Fe} 2 \mathrm{O} 3-\mathrm{Al} 2 \mathrm{O} 3-\mathrm{TiO} 2-\mathrm{SiO} 2$ liquids: new measurements and derived partial molar properties. Geochim Cosmochim Acta 51(11): 2931-2946. https://doi.org/10.1016/0016-7037(87)90368-1

Le Maitre RW (1976) The chemical variability of some common igneous rocks. J Petrol 17(4):589-598. https://doi.org/10.1093/petrology/17. 4.589

Mahood GA, Hildreth W (1986) Geology of the peralkaline volcano at Pantelleria, Strait of Sicily. Bull Volcanol 48(2-3):143-172. https:// doi.org/10.1007/BF01046548

Mastrolorenzo G, Palladino DM, Pappalardo L, Rossano S (2017) Probabilistic-numerical assessment of pyroclastic current hazard at Campi Flegrei and Naples city: multi-VEI scenarios as a tool for "full-scale" risk management. PLoS One 12(10):e0185756. https:// doi.org/10.1371/journal.pone.0185756

McDonough WF, Sun S-S (1995) The composition of the Earth. Chem Geol 120(3-4):223-253. https://doi.org/10.1016/0009-2541(94) $00140-4$

McKee CO, Duncan RA (2016) Early volcanic history of the Rabaul area. Bull Volcanol 78(4):24. https://doi.org/10.1007/s00445-016-1018-3

McKee CO, Johnson RWPL, Riley SJ, Blong RJ, De Saint Ours P, Talai B (1985) Rabaul caldera, Papua New Guinea: volcanic hazards, surveillance, and eruption contingency planning. J Volcanol Geotherm Res 23(3-4):195-237. https://doi.org/10.1016/03770273(85)90035-6

Mitchell SJ, Houghton BF, Carey RJ, Manga M, Fauria KE, Jones MR, Coule AS, Conway CH, Wei Z, Giachetti T (2019) Submarine giant pumice: a window into the shallow conduit dynamics of a recent silicic eruption. Bull Volcanol 81:42. https://doi.org/10.1007/ s00445-019-1298-5

Miyabuchi Y (2011) Post-caldera explosive activity inferred from improved 67-30 ka tephrostratigraphy at Aso Volcano, Japan. J Volcanol Geotherm Res 205(3-4):94-113. https://doi.org/10.1016/ j.jvolgeores.2011.05.004
Moitra P, Gonnermann HM, Houghton BF, Giachetti T (2013) Relating vesicle shapes in pyroclasts to eruption styles. Bull Volcanol 75(2): 1-14. https://doi.org/10.1007/s00445-013-0691-8

Moore RB (1991) Geological map of Sao Miguel, Azores. US Department of Interior. USGS. https://doi.org/10.3133/i2007

Mueller S, Scheu B, Kueppers U, Spieler O, Richard D, Dingwell DB (2011) The porosity of pyroclasts as an indicator of volcanic explosivity. J Volcanol Geotherm Res 3-4:168-174. https://doi. org/10.1016/j.jvolgeores.2011.04.006

Neave DA, Fabbro G, Herd RA, Petrone CM, Edmonds M (2012) Melting, differentiation and degassing at the Pantelleria volcano, Italy. J Petrol 53(3):637-663. https://doi.org/10.1093/petrology/ egr074

Newhall CG, Self S (1982) The volcanic explosivity index ( VEI): an estimate of explosive magnitude for historical volcanism. J Geophys Res 87(C2):1231-1238. https://doi.org/10.1029/jc087ic02p01231

Nielson DL, Sibbett BS (1996) Geology of Ascension Island, South Atlantic Ocean. Geothermics 25(4-5):427-448. https://doi.org/10. 1016/0375-6505(96)00018-1

Orsi G, Ruvo L, Scarpati C (1989) The Serra della Fastuca Tephra at Pantelleria: physical parameters for an explosive eruption of peralkaline magma. J Volcanol Geotherm Res 39(1):55-60. https://doi.org/10.1016/0377-0273(89)90020-6

Orsi G, Ruvo L, Scarpati C (1991) The recent explosive volcanism at Pantelleria. Geol Rundsch 80(1):187-200. https://doi.org/10.1007/ BF01828776

Pistolesi M, Cioni R, Bonadonna C, Elissondo M, Baumann V, Bertagnini A, Chiarai L, Gonzales R, Rossi M, Francalanci L (2015) Complex dynamics of small-moderate volcanic events: the example of the 2011 rhyolitic Cordón Caulle eruption, Chile. Bull Volcanol 77(1). https://doi.org/10.1007/s00445-014-0898-3

Polacci M (2005) Constraining the dynamics of volcanic eruptions by characterization of pumice textures. Ann Geophys 48(4):731-738 http://hdl.handle.net/2122/934

Polacci M, Pioli L, Rosi M (2003) The Plinian phase of the Campanian Ignimbrite eruption (phlegrean fields, Italy): evidence from density measurements and textural characterization of pumice. Bull Volcanol 65(6):418-432. https://doi.org/10.1007/s00445-002$0268-4$

Preece K, Gertisser R, Barclay J, Berlo K, Herd RA (2014) Pre-and syneruptive degassing and crystallisation processes of the 2010 and 2006 eruptions of Merapi volcano, Indonesia. Contrib Mineral Petrol 168(4):1061. https://doi.org/10.1007/s00410-014-1061-z

Preece K, Mark DF, Barclay J, Cohen BE, Chamberlain KJ, Jowitt C, Vye-Brown C, Brown RJ, Hamilton S (2018) Bridging the gap: $40 \mathrm{Ar} / 39 \mathrm{Ar}$ dating of volcanic eruptions from the 'Age of Discovery'. Geology 46(12):1035-1038. https://doi.org/10.1130/ g45415.1

Preece KJ, Barclay J, Brown RJ, Chamberlain KJ, Mark DF (2021) Explosive felsic eruptions on ocean islands: a case study from Ascension Island (South Atlantic). J Volcanol Geotherm Res 416: 107284. https://doi.org/10.1016/j.jvolgeores.2021.107284

Pyle DM (2015) Sizes of volcanic eruptions. In: Sigurdsson H (ed) The Encyclopedia of Volcanoes, 2nd edn. Academic, Cambridge, pp 257-264. https://doi.org/10.1016/B978-0-12-385938-9.00013-4

Queiroz G, Pacheco JM, Gaspar JL, Aspinall WP, Guest JE, Ferreira T (2008) The last 5000 years of activity at Sete Cidades volcano (São Miguel Island Azores): Implications for hazard assessment. J Volcanol Geotherm Res 178(3):562-573. https://doi.org/10.1016/j. jvolgeores.2008.03.001

Rapprich V, Žáček V, Verner K, Erban V, Goslar T, Bekele Y, Legesa F, Hroch T, Hejtmánková P (2016) Wendo Koshe Pumice: the latest Holocene silicic explosive eruption product of the Corbetti Volcanic System (Southern Ethiopia). J Volcanol Geotherm Res 310:159171. https://doi.org/10.1016/j.jvolgeores.2015.12.008 
Robinson JE, Eakins BW (2006) Calculated volumes of individual shield volcanoes at the young end of the Hawaiian Ridge. J Volcanol Geotherm Res 151(1-3):309-317. https://doi.org/10.1016/j. jvolgeores.2005.07.033

Rotolo SG, La Felice S, Mangalaviti A, Landi P (2007) Geology and petrochemistry of the recent $(<25 \mathrm{ka})$ silicic volcanism at Pantelleria Island. Boll Soc Geol Ital 126(2):191

Rust AC, Cashman KV, Wallace PJ (2004) Magma degassing buffered by vapor flow through brecciated conduit margins. Geology 32(4): 349-352. https://doi.org/10.1130/G20388.2

Saubin E, Tuffen H, Gurioli L, Owen J, Castro JM, Berlo K, McGowan EM, Schipper CI, Wehbe K (2016) Conduit dynamics in transitional rhyolitic activity recorded by tuffisite vein textures from the 20082009 Chaitén eruption. Front Earth Sci 4(May). https://doi.org/10. 3389/feart.2016.00059

Sbrana A, Marianelli P, Pasquini G (2018) Volcanology of Ischia (Italy). J Maps 14(2):494-503. https://doi.org/10.1080/17445647.2018. 1498811

Schipper CI, Castro JM, Tuffen H, James MR, How P (2013) Shallow vent architecture during hybrid explosive-effusive activity at Cordón Caulle (Chile, 2011-12): evidence from direct observations and pyroclast textures. J Volcanol Geotherm Res 262:25-37. https:// doi.org/10.1016/j.jvolgeores.2013.06.005

Scott WE, Hoblitt RP, Torres RC, Self S, Martinez MML, Nillos T (1996) Pyroclastic flows of the June 15, 1991, climactic eruption of Mount Pinatubo. In: Newhall CG, Punongbayan RS (eds) Fire and mud: Eruptions and lahars of Mount Pinatubo, Philippines. Philippine institute of Volcanology and Seismology, pp 545-570

Shea T, Houghton BF, Gurioli L, Cashman KV, Hammer JE, Hobden BJ (2010) Textural studies of vesicles in volcanic rocks: an integrated methodology. J Volcanol Geotherm Res 190(3-4):271-289. https:// doi.org/10.1016/j.jvolgeores.2009.12.003

Shea T, Gurioli L, Houghton BF (2012) Transitions between fall phases and pyroclastic density currents during the AD 79 eruption at Vesuvius: building a transient conduit model from the textural and volatile record. Bull Volcanol 74(10):2363-2381. https://doi.org/10. 1007/s00445-012-0668-z

Shea T, Leonhardi T, Giachetti T, Lindoo A, Larsen J, Sinton J, Parsons E (2017) Dynamics of an unusual cone-building trachyte eruption at
$\mathrm{Pu}^{\prime} u$ Wa'awa'a, Hualālai volcano, Hawai'i. Bull Volcanol 79(4). https://doi.org/10.1007/s00445-017-1106-Z

Sieron K, Ferres D, Siebe C, Capra L, Constantinescu R, AugustÍn-Flores J, Zuccolotto G, Böhnel H, Connor L, Connor CB, Groppelli G (2019) Ceboruco hazard map: part I - definition of hazard scenarios based on the eruptive history. J Appl Volcanol 8(9). https://doi.org/ 10.1186/s13617-019-0088-2

Singer BS, Jicha BR, Harper MA, Naranjo JA, Lara LE, Moreno-Roa H (2008) Eruptive history, geochronology, and magmatic evolution of the Puyehue-Cordón Caulle volcanic complex, Chile. Geol Soc Am Bull 120(5-6):599-618. https://doi.org/10.1130/B26276.1

Sparks RSJ (1978) The dynamics of bubble formation and growth in magmas: a review and analysis. J Volcanol Geotherm Res 3(1-2): 1-37. https://doi.org/10.1016/0377-0273(78)90002-1

Stewart AL, McPhie J (2006) Facies architecture and Late PliocenePleistocene evolution of a felsic volcanic island, Milos, Greece. Bull Volcanol 68(7-8):703-726. https://doi.org/10.1007/s00445005-0045-2

Toramaru A (2006) BND (bubble number density) decompression rate meter for explosive volcanic eruptions. J Volcanol Geotherm Res 154(3-4):303-316. https://doi.org/10.1016/j.jvolgeores.2006.03. 027

Toramaru A, Noguchi S, Oyoshihara S, Tsune A (2008) MND(microlite number density) water exsolution rate meter. J Volcanol Geotherm Res 175(1-2):156-167. https://doi.org/10.1016/j.jvolgeores.2008. 03.035

Vezzoli L, Principe C, Malfatti J, Arrighi S, Tanguy JC, Le Goff M (2009) Modes and times of caldera resurgence: the $<10$ ka evolution of Ischia Caldera, Italy, from high-precision archaeomagnetic dating. J Volcanol Geotherm Res 186(3-4):305-319. https://doi.org/10. 1016/j.jvolgeores.2009.07.008

Weaver B, Kar A, Davidson J, Colucci M (1996) Geochemical characteristics of volcanic rocks from Ascension Island, south Atlantic Ocean. Geothermics 25(4-5):449-470. https://doi.org/10.1016/ 0375-6505(96)00014-4

Whittington A, Richet P, Linard Y, Holtz F (2001) The viscosity of hydrous phonolites and trachytes. Chem Geol 174(1-3):209-223. https://doi.org/10.1016/S0009-2541(00)00317-X 